
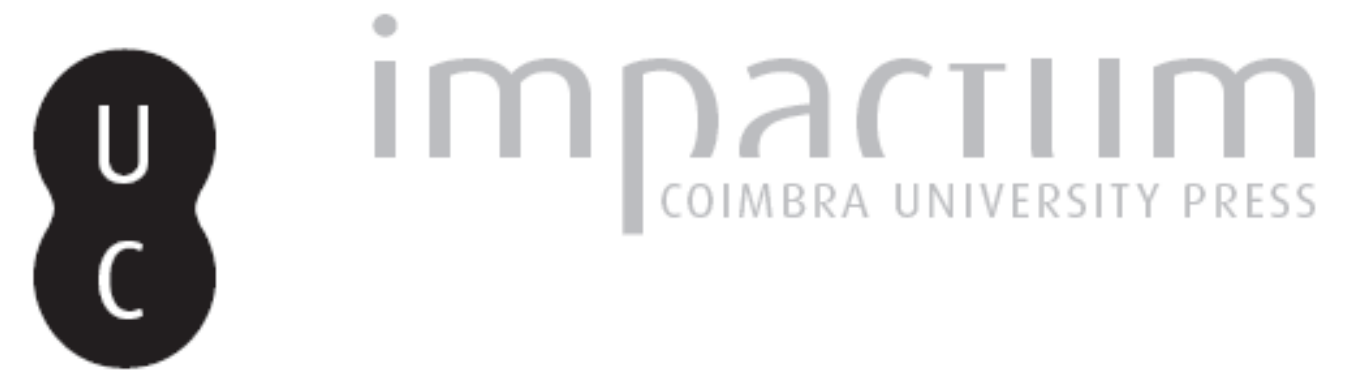

\title{
António Sérgio, Ministro da Instrução Pública
}

Autor(es): $\quad$ Fernandes, Rogério

Publicado por: Imprensa da Universidade de Coimbra

URL persistente:

URI:http://hdl.handle.net/10316.2/45057

DOI:

DOI:https://doi.org/10.14195/2183-8925_5-2_1

Accessed : $\quad$ 26-Apr-2023 11:36:56

A navegação consulta e descarregamento dos títulos inseridos nas Bibliotecas Digitais UC Digitalis, UC Pombalina e UC Impactum, pressupõem a aceitação plena e sem reservas dos Termos e Condições de Uso destas Bibliotecas Digitais, disponíveis em https://digitalis.uc.pt/pt-pt/termos.

Conforme exposto nos referidos Termos e Condições de Uso, o descarregamento de títulos de acesso restrito requer uma licença válida de autorização devendo o utilizador aceder ao(s) documento(s) a partir de um endereço de IP da instituição detentora da supramencionada licença.

Ao utilizador é apenas permitido o descarregamento para uso pessoal, pelo que o emprego do(s) título(s) descarregado(s) para outro fim, designadamente comercial, carece de autorização do respetivo autor ou editor da obra.

Na medida em que todas as obras da UC Digitalis se encontram protegidas pelo Código do Direito de Autor e Direitos Conexos e demais legislação aplicável, toda a cópia, parcial ou total, deste documento, nos casos em que é legalmente admitida, deverá conter ou fazer-se acompanhar por este aviso. 


\section{REVISTA DE HISTÓRIA DAS IDEIAS 5}

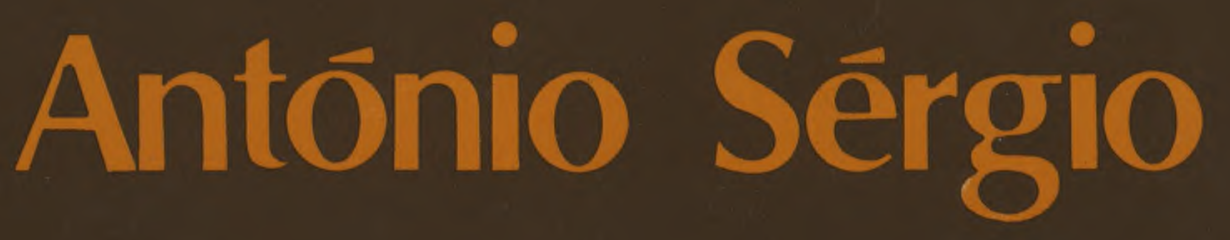

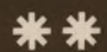

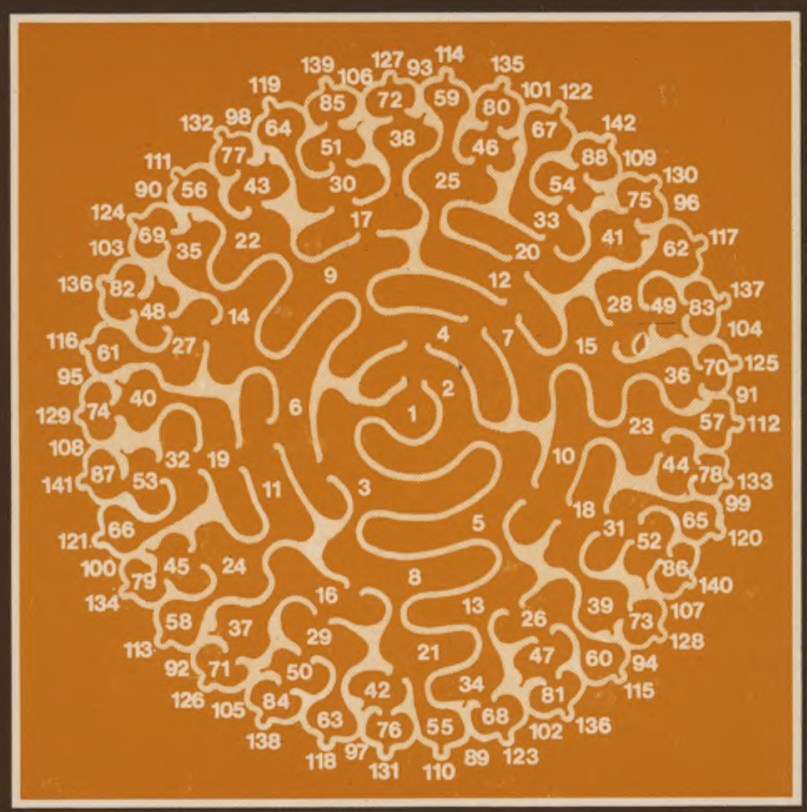

INSTITUTO DE HISTÓRIA E TEORIA DAS IDEIAS FACULDADE DE LETRAS

COIMBRA 1983 


\section{ANTÓNIO SÉRGIO, MINISTRO DA INSTRUÇÃO PÚBLICA}

Estudar a acção de António Sérgio como ministro da Instrução Pública, na sua passagem fugaz pelo Poder entre 18 de Dezembro de 1923 e 28 de Fevereiro de 1924, terá porventura algum interesse para além do plano biográfico? Tentando perseguir os passos do autor dos Ensaios durante esse curtíssimo trajecto de setenta e três dias, acaso não nos arriscamos a cair no anedotismo empírico em que se compraz tantas vezes a historiografia nacional da educação?

Sendo certo que não deixa de ter certo fascínio a análise dessa confrontação episódica do intelectual idealista com as rugosidades de um «real político» exposto à sua intervenção directa, o nosso escopo é bem diverso. Longe de pretendermos preencher uma espécie de certidão de vita et moribus que reconduza António Sérgio à escala humana, trata-se, no fundamental, de reconsiderar um momento preciso da política de educação da 1. ${ }^{a}$ República, inserindo tal exame no quadro geral dos problemas relativos à estruturação e funcionamento dos sistemas de ensino.

Deste modo, eis-nos remetidos para o território da história social da educação, tão sujeito, nestes dias de hoje, aos desafios de territórios vizinhos, designadamente da história e da sociologia 0 ).

* Ensaista.

C) Cf. Antoine Léon, Introduction à Vhistoire des faits éducatifs, Paris, P.U.F., 1980 e ainda, L'histoire de l'éducation aujourd'hui. Champ. Orientations. Fonctions, Paris, U.E.R. de l'éducation - Paris V, 1982, (mimeog.), cujo conhecimento devemos à amabilidade do autor.

Quanto aos problemas teóricos enfrentados em sociologia da educação, cf. Margaret S. Archer, «Systèmes d'enseignement», Revue internationale de sciences sociales. L'historiographie moderne. Discipline scientifique? Discipline littéraire?, 38 (4), Paris, Unesco, 1981, pp. 284 ss. 
Por nossa parte, e antes de mais, ambicionamos repensar os esforços de António Sérgio no sentido da reestruturação do sistema de ensino, determinar-lhes a significação perante as forças sociais e políticas em presença, reconstituir o processo de negociação social daí emergente e, por fim, as suas consequências. Para tudo dizer em poucas palavras, importa-nos essencialmente a reavaliação objectiva da política de educação de António Sérgio no âmbito da transformação das estruturas educativas portuguesas após a revolução republicana.

Como instituição macro-social, o sistema de ensino está ligado aos traços essenciais da sociedade global e da sua evolução. Relação complexa e frequentemente contraditória, se ela interdiz o estabelecimento de correspondências lineares entre as duas estruturas, aponta, contudo, no sentido da determinação das respectivas interfaces.

\section{Sociedade portuguesa e sistema de ensino entre 1910 e 1923}

Num breve mas sugestivo estudo da evolução económico-social portuguesa entre 1910 e 1925, salientou Armando de Castro que a proclamação do regime republicano não alterou as linhas dominantes em que se operava o ritmo do crescimento económico.

O subdesenvolvimento português continua a caracterizar a 1. ${ }^{a}$ República tal como caracterizara a Monarquia. O predomínio das actividades primárias é o seu índice mais evidente: em 1925 perto de metade da nossa população activa empregava-se na agricultura. Apenas duas regiões - Lisboa e Porto - haviam alcançado um grau de industrialização acima da média, seguidas de algumas zonas dos distritos de Aveiro, Braga e Setúbal. Em 1911 a parte da população industrial na população activa oscilava entre $1,8 \%$ no distrito de Beja e $20,5 \%$ no do Porto $\left({ }^{2}\right)$.

(2) Para tudo o que precede ver: Armando de Castro, Características principais e sentido da evolução económico-social de 1910 a 1925, in «História ilustrada das grandes literaturas. Literatura portuguesa. Época Contemporânea», Lisboa, Editorial Estúdios Cor, s.d., pp. 441 ss.; id., $A$ revolução industrial em Portugal no século $X X, 4 .^{\mathrm{a}}$ ed., Porco, Limiar, 1978; António Viana Martins, Da l República ao Estado Novo, Lisboa, Iniciativas Editoriais, 1976; Fernando Medeiros, $A$ Sociedade e a economia portuguesa nas origens do salazarismo, Lisboa, A Regra do Jogo, 1978; António José Telo, Decadência e queda da 1 República Portuguesa, $10^{\circ}$ vol., Lisboa, A Regra do Jogo, 1980; História da l.a República Portuguesa, dir. de A. H. de Oliveira Marques, Lisboa, Iniciativas Editoriais, s.d. 
A emigração para o exterior e a emigração interna para centros urbanos (na sua maior parte, contudo, semi-rurais), a par de intensas lutas sociais tanto nas cidades como nos campos, traduzem a resistência, por um lado, das populações camponesas à proletarização crescente em proveito dos grandes agrários e, por outro, da classe operária ao agravamento constante das condições de vida e de trabalho $\left({ }^{3}\right)$.

Se é facto, porém, que, até 1925, Armando de Castro tem justos motivos para assinalar a persistência do "atraso português relativamente aos países europeus mais evoluídos» (para um salário real operário igual a 100, em Londres, o seu índice em Lisboa seria de 32, de 55 em Berlim, de 214 em Filadélfia), a realidade económico-social portuguesa não estava imóvel.

Desenvolvem-se neste período as primeiras grandes unidades fabris, tais como a CUF, no Barreiro, os cimentos, em Leiria, as conservas, a cerveja, a moagem, as massas alimentícias, a metalomecânica pesada, etc. Sem perder de vista o carácter relativo destes índices, a partir de 1914-1919 é mais vultosa pela primeira vez em Portugal a parte do capital das sociedades que se consagram à indústria do que a daquelas que se dedicam ao comércio. Em 1914 registavam-se unicamente 285 sociedades industriais. Dez anos depois, o seu número é de 1359, agrupando, na sua maioria, pequenos capitais.

Assim, durante a 1. ${ }^{a}$ República, a pequena e média empresa detinham predomínio apreciável na indústria, no comércio, na agricultura e até na banca. Sem embargo da existência de monopólios, não existiam ainda grandes grupos monopolistas e o capital financeiro não dominava a economia portuguesa, afirma Âlvaro Cunhal num dos seus ensaios. «O desenvolvimento industrial esbarrava com o fraco nível de acumulação, a escassez de capital — dinheiro indispensável aos grandes investimentos - a indigência energética e o primitivismo do sector I da produção (produção de meios de produção), acrescenta. $\mathrm{O}$ colonialismo português e as posições do imperialismo estrangeiro em Portugal, embora com influências contraditórias, constituiram no essencial entraves adicionais à acumulação do capital e ao desenvolvimento económico do país» $\left({ }^{4}\right)$.

(3) Cf. designadamente César Oliveira, O operariado e a república democrática. 1910-1914, Porto, Afrontamento, 1972; António Ventura, Subsídios para a história do movimento sindical rural no Alto Alentejo. 1910-1914, Lisboa, Seara Nova, 1976.

(4) Álvaro Cunhal, O radicalismo pequeno-burguês de fachada socialista, 3. a ed., Lisboa, Edições Avante!, 1974, p. 19. 
O desenvolvimento educacional reflectia as linhas fundamentais do desenvolvimento económico ao longo do período considerado.

Desde a proclamação da República até à entrada de António Sérgio no Ministério da Instrução, o sistema de ensino perfilhado pelo Poder republicano conservou os traços essenciais do legado monárquico.

O seu primeiro aspecto saliente é a persistência de uma insuficiente escolarização ao nível do ensino primário elementar. A taxa de analfabetismo, que em 1910 rondaria os 76,1\%, terá descido apenas para $70,5 \%$ dez anos depois $(5)$. Por outro lado, a frequência do citado grau de ensino e consequentemente a aplicação efectiva do princípio da obrigatoriedade escolar registam importantes flutuações. A percentagem de crianças inscritas nas escolas primárias oficiais, relativamente aos totais de recenseadas, era de 43,5\% em 1911-1912, de $30,5 \%$ em 1916-1917 e de 25,7\% em 1918-1919 (6).

A análise estatística vem comprovar, adicionalmente, que a fuga ao cumprimento da escolaridade primária era muito mais pronunciada quanto ao sexo feminino $\left({ }^{7}\right)$.

Entre as causas do decréscimo de matrículas, particularmente evidenciado em 1918-1919, os próprios responsáveis pelo ensino colocavam em primeiro lugar «a falta duma eficaz e bem distribuída assistência escolar» $\left.{ }^{8}\right)$. Embora se não conferisse carácter exclusivo a este condicionalismo, ele confirma, de modo indirecto, serem as crianças procedentes das classes populares as mais afectadas por uma escolarização elementar insuficiente. $\mathrm{O}$ trabalho infantil e juvenil constituía obstáculo insuperável ao acesso à escola ${ }^{9}$ ).

Sobre esta base precária, o sistema de ensino divergia em duas grandes vias a partir da escola primária elementar. Em paralelo com a sequência ensino liceal - ensino superior e

(5) Rui Grácio, Ensino Primário e Analfabetismo, in «Dicionário de História de Portugal», dir. de Joeí Serrão, vol. 2, Lisboa, Iniciativas Editoriais, s.d., p. 53.

(6) José Salvado Sampaio, O ensino primário. 1911-1969. Contribuição monográfica, vol. 1, l. $0^{\circ}$ período. 1911-1926, Lisboa, Instituto Gulbenkian de Ciềncia-Centro de Investigação Pedagógica, 1975, p. 44.

O Idem, ibidem.

C) Idem, p. 43.

(9) A nossa história industrial, diz-nos Armando de Castro, registou em 1910 pelo menos um movimento grevista de crianças entre os 6 e os 11 anos de idade. Em 1921, numa empresa têxtil, em Castanneir? de Pera, os menores trabalhavam como os adultos, 16 horas por dia, das 5 ou 6 da manhã à meia-noite (A revolução..., cit., p. 179 e nt. 1). 
universitário existiam as sequências técnico-profissionais de carácter industrial, comercial e agrícola e respectivos institutos médios.

Do ponto de vista institucional não se podia dizer, a rigor, que as vias técnico-profissionais integrassem propriamente o sistema de ensino. Em 1923-1924, dez anos após a criação do Ministério da Instrução Pública, as vias técnico -profissionais dependiam dos Ministérios do Comércio e Comunicações e da Agricultura, onde dispunham de serviços próprios.

Esta dualidade tinha uma função social evidente. A sequência ensino liceal - ensino superior e universitário abria caminho aos mais elevados escalões das profissões liberais e do alto funcionalismo. As vias técnico-profissionais, abrangendo escolas técnicas elementares, de artes e ofícios e institutos médios facultavam o ingresso nos postos inferiores e médios do sistema produtivo e do aparelho do Estado.

Mantendo intactos os traços essenciais deste sistema, a 1. ${ }^{a}$ República fizera-o entrar, porém, num ciclo de reelaborações parciais.

Ao nível elementar, a principal disposição reformadora consistiu na criação das escolas móveis oficiais, destinadas a promover a instrução primária de crianças, adolescentes e adultos nas freguesias onde não fosse exequível o estabelecimento de escolas fixas $\left({ }^{10}\right)$.

Após um período de quebra de inscrições, o número de inscritos nas escolas móveis estabilizara na média de 14000 alunos, com acentuada predominância do sexo masculino.

Ao nível pós-elementar, a l. ${ }^{a}$ República cria o ensino primário superior como via alternativa ao ensino secundário $\left({ }^{\mathrm{xl}}\right)$.

Segundo a reforma de 29 de Março de 1911, abrangendo os ensinos infantil e primário, este último ensino dividir-se-ia em três graus. O grau elementar, com três anos de duração, frequentável a partir dos 7 anos, seria seguido do complementar ( 2 anos), para os indivíduos com não menos de 10 anos de idade, e do superior (3 anos), para os indivíduos com o mínimo de 12 anos de idade, aprovados no complementar ou equivalente.

(10) José Salvado Sampaio, «Escolas Móveis. Contribuição monográfica» in Boletim Bibliográfico e Informativo, (9), Lisboa, Fundação Calouste Gulbenkian-Centro de Investigação Pedagógica, 1969.

(n) $O$ único estudo global deste grau de ensino deve-se a José Salvado Sampaio, «O Ensino Primário Superior. Contribuição monográfica», in Boletim..., cit., (12), Lisboa, 1970. 
O ensino primário superior aparece concebido como um grau de ensino polivalente, integrando ao mesmo tempo finalidades de preparação para o prosseguimento de estudos e objectivos de natureza profissionalizante ou prática. As respectivas escolas destinar-se-iam não somente ao aperfeiçoamento dos conhecimentos obtidos nas elementares e complementares, «mas também, e principalmente, a estimular, desenvolver e educar, por uma aprendizagem conveniente, nos alunos que as frequentam, as aptidões naturais que possuam e que desejam valorizar para a vida» $\left({ }^{12}\right)$.

Deste modo, o curso geral ambicionava compreender um vasto conjunto de matérias: língua portuguesa, duas línguas estrangeiras (francês e inglês), historia (especialmente a de Portugal), geografia geral (especialmente a de Portugal e colónias) e económica, noções de economia, direito usual, matemáticas elementares (aritmética, geometria, álgebra e agrimensura), contabilidade, ciências físico-químicas e histórico-naturais e suas aplicações, designadamente à agricultura, ao comércio e à indústria, consoante as necessidades regionais, desenho, higiene, moral, instrução cívica, educação física, exercícios militares, ginástica, jogos, natação, remo, etc., música, canto coral, prática em aulas - escritório, estenografia, oficinas, campos experimentais. Este curso geral teria, porém, cursos práticos especiais, "para o ensino agrícola, industrial, comercial ou marítimo, consoante as necessidades das regiões a que as escolas pertençam» e de harmonia com programas adequados às diversas secções (1S).

Esta nova componente do ensino primário apresentava graus diversos de permeabilidade quanto à sequência de estudos e à inserção na vida activa.

Com efeito, o respectivo certificado daria acesso à classe correspondente do ensino liceal, mediante exame de admissão cujo programa se prometia decretar ulteriormente. A sequência de estudos não ficava, portanto, automaticamente assegurada em relação à via ensino liceal - ensino superior. Em contrapartida, o mesmo certificado permitiria, sem restrições, a matrícula nas escolas normais primárias (transformadas, pelo mesmo decreto, em escolas primárias superiores, bem como as de habilitação para o magistério primário), nos cursos regulares das escolas industriais, agrícolas, comerciais, profissionais e técnicas, além de que dispensaria da prestação de provas públicas para o exercício de todos os cargos oficiais

$\left.C^{2}\right)$ Decreto de 29 de Março de 1911, art. 32..

(13) Idem, art. ${ }^{\circ} 1 .^{\circ}$. 
de categoria inferior a $400 \$ 000$ réis, exceptuados os que fossem de competência técnica $\left({ }^{14}\right)$.

Ministrado com carácter facultativo, laico, gratuito e em regime de coeducação de sexos, o ensino primário superior pretendia constituir, pois, uma alternativa ao secundário liceal (muito insuficientemente desenvolvido em relação ao sexo feminino) mas, sobretudo, uma via de preparação profissional, com particular incidência na formação docente para o ensino elementar.

As classes populares e os sectores intermédios da sociedade portuguesa - a pequena-burguesia urbana - seriam, em princípio, os principais beneficiários deste novo grau de ensino. Assim, o governo provisório cometia às câmaras municipais o encargo da criação de escolas primárias superiores em todos os bairros de Lisboa e Porto, nas capitais de distrito, em todas as povoações de população aglomerada superior a 10000 habitantes, e em todos os centros fabris ou comerciais de importância reconhecida.

As despesas principais com o ensino primário, no seu conjunto, ficariam, de resto, a cargo dos municípios (cabendo ao Estado apenas as relativas à direcção e fiscalização).

Quanto ao pessoal docente das escolas primárias superiores, seria nomeado pelo Governo de entre os habilitados com o curso da escola normal superior ou de entre professores de instrução primária, precedendo concurso de provas públicas. Os professores dos cursos práticos e os mestres das oficinas das citadas escolas seriam contratados pelos Municípios, sob parecer do Conselho Superior de Instrução Pública, de entre indivíduos nacionais ou estrangeiros, portadores de adequadas habilitações $\left({ }^{15}\right)$.

Recaindo sobre os municípios os encargos mais vultosos quanto ao ensino primário superior, não é de surpreender que o início do seu efectivo funcionamento ocorresse apenas sete anos depois (16).

Ao tentar-se a concretização prática do ensino primário superior, a ambiguidade dos seus objectivos toma-se patente. A sucessão de disposições legislativas de que é objecto, a partir de 1919, reflecte as indeterminações do processo de desenvolvimento económico-social que, em princípio, se destinava a apoiar. Mantendo sempre articulação com outros graus e ramos de ensino, as escolas primárias superiores vêem oscilar cit., p. 35.

(14) Idem, art.os $33 .^{\circ}$ e $34 .^{\circ}$.

(18> Idem, art. ${ }^{08} 35^{\circ}, 52^{\circ}, 53 .^{\circ}$ e $81 .^{\circ}$.

(“) José Salvado Sampaio, O Ensino Primário Superior..., 
entre finalidades bem diversas os objectivos propostos ao seu currículo.

Assim, em 1919, as escolas primárias superiores tendem a ganhar o carácter de escolas técnicas profissionais. A 5 de Maio desse ano, o decreto n. ${ }^{\circ} 5504$ transforma em escolas superiores as antigas escolas normais de Lisboa, Porto e Coimbra, bem como as de habilitação para o magistério do ensino primário. $\mathrm{O}$ pessoal docente das escolas normais e de habilitação transita para os estabelecimentos em que foram convertidas. Cinco dias depois, o decreto $n .^{\circ}$ 5787-B, capitulando de particular interesse para «a grande massa popular» este grau de ensino, pretende associar por seu intermédio a educação geral e a preparação técnica de carácter geral, facultando a existência de secções comerciais, agrícolas, industriais, marítimas e domésticas, em regime de opção após o $1 .^{\circ}$ ano de escolaridade.

O diploma das escolas primárias superiores habilitaria à matrícula nas escolas normais primárias e na parte especializada das correspondentes escolas técnicas, e bem assim a requerer exame final do curso geral dos liceus, $2 .^{a}$ secção. Permitia, ainda, obter o diploma de aptidão pedagógica nas escolas normais primárias com vista à docência no ensino primário particular, bem como o concurso a todos os cargos públicos para cujo provimento se exigisse o exame de saída do curso geral dos liceus. Constituiria, ainda, factor preferencial de admissão em fábricas, oficinas, arsenais ou quaisquer outros estabelecimentos estatais, ao passo que as diplomadas pela secção doméstica teriam a preferência quanto ao ingresso nos quadros do pessoal menor ou vigilante nos estabelecimentos de educação e ensino $\left({ }^{17}\right)$.

Estas disposições legais não viriam, contudo, a concretizar-se tão cedo. Só em Dezembro de 1921 se determinaria a criação provisória, e a título experimental, de secções técnicas comerciais nas escolas primárias superiores de Lisboa e Porto. Após essa experiência, apenas em 7 de Setembro de 1923 vemos abrir-se a porta à criação efectiva das secções previstas no decreto n. ${ }^{\circ} 5787-\mathrm{B}$ !

Entretanto, e não obstante o carácter democrático que se pretende atribuir às escolas primárias superiores, a ver-

(1T) Idem, pp. 37-38. Em escolas primárias superiores obtidas por conversão das antigas escolas normais e de habilitação para o magistério, a coexistência de corpos docentes com preparações muito diferenciadas originava dificuldades consideráveis, a ajuizar pelos conflitos havidos em Leiria e de que o jornal $\boldsymbol{A}$ Verdade nos dá testemunho. (Cf. A Verdade, Leiria, 1922-1923). 
dade é que o seu funcionamento revelava contradições dificilmente sanáveis.

Em primeiro lugar, os critérios de implantação da respectiva rede e de preenchimento dos seus quadros de docentes e funcionários parecem ter obedecido a pressões de carácter político indefensável mais do que à consideração da necessidade social e da competência profissional.

Desse modo, o decreto n. ${ }^{\circ} 7082$, de 14 de Novembro de 1921, se qualifica de «profundamente democrático» o ensino primário superior, atribuindo-lhe essa função, quanto à cultura geral, «especialmente nos pontos em que a carência de escolas secundárias mais acentuadamente se fazia sentir, como sucede nos centros industriais e agrícolas» (18), pretende todavia corrigir, por um lado, as distorsões da rede escolar e, por outro lado, o excesso de professores e de empregados, o qual, em certos casos, superaria o número de alunos.

A mesma preocupação de obviar à pletora de docentes e funcionários origina ulteriormente várias tentativas de redução dos quadros das escolas primárias superiores. A sucessão de disposições legais tomadas em tal sentido testemunha sobre a amplitude das resistências encontradas. É o que comprovam o decreto n. ${ }^{\circ} 8491$, de 17 de Novembro de 1922, logo suspenso a 30 de Dezembro do mesmo ano pelo decreto n. ${ }^{\circ}$ 8556 , o decreto n. $^{\circ} 8932$, de 19 de Julho de 1923 , e a lei n. ${ }^{\circ} 1448$, de 12 de Junho do mesmo ano, repondo em vigor o decreto n. ${ }^{\circ} 8491$ do final do ano precedente.

Não obstante o facto de se considerar que tais escolas dispunham de professores e empregados em excesso face às necessidades, a lei n. ${ }^{\circ} 1068$, de 18 de Novembro de 1920, condicionaria o ingresso nas escolas primárias superiores a uma prova de admissão, cujo programa viria a ser publicado no ano seguinte, identificando-o com o da $5 .{ }^{\text {a }}$ classe do então ensino primário geral, exceptuadas as disciplinas de Trabalhos Manuais, Música e Educação Física.

Em que medida a procura do ensino primário superior testemunha sobre a existência real de uma necessidade a que se destinaria a responder?

Dispomos de dados estatísticos a partir do ano lectivo de 1919-1920 até 1924-1925, embora só retenhamos o período que nos interessa.

O número de estabelecimentos de ensino primário superior oscila entre 50 e 51 desde o ano lectivo considerado até ao de 1923-1924. De 3646 alunos inscritos no $1 .^{\circ}$ e $2 .^{\circ}$ anos

(18) José Salvado Sampaio, ob. cit., pp. 41-42. 
do novo curso do ensino primário superior em 1920-1921, passa-se para 2311 em 1923-1924.

Aparentemente, esta quebra de inscrições denotaria considerável diminuição da procura. A verdade, porém, é que no ano de 1921 se apresentam 510 candidatos à admissão (índice 100), ao passo que no ano de 1923 se apresentam 1413 (índice 277). A percentagem de aprovações nesse exame passa de 92,7 em 1921 para $94,7 \%$ em $1923(19)$.

Embora, globalmente, o número de alunos do sexo masculino tenha diminuído de 1336, em 1920-1921, para 1016 em 1922-1923 e 973 em 1923-1924, a sua percentagem, relativamente aos totais de inscritos, passa de 29,8 para 42,1 naqueles anos extremos. Apesar disso, porém, as escolas primárias superiores são essencialmente femininas, o que se explica pela natureza dos seus objectivos e pelo insuficientíssimo desenvolvimento do ensino liceal para aquele sexo.

As taxas de aprovação e de conclusão apresentam índices diversos. Quanto às primeiras, a percentagem foi de 77,8 em 1920-1921, baixando para 69,2 e 65,8 nos dois anos lectivos seguintes, ao passo que em 1923-1924 volta a subir para 72,6. Relativamente às conclusões, a taxa foi de $18,6 \mathrm{em} 1920-$ -1921, subindo para 19,9, em 1921-1922, 23,2 em 1922-1923, e descendo para 21,9 em 1923-1924. Não se pode afirmar, pois, que as escolas primárias superiores apresentem produtividade elevada.

Quanto à estrutura do corpo docente, a percentagem de professores do sexo masculino, como observa José Salvado Sampaio, excede em todos os anos dois terços do total, com uma variação fraca de 70,7 em 1923-1924 e de 67,4 em 1924-1925.

Sobressai também a elevada percentagem de professores efectivos, atingindo os 97,6 em 1921-1922 (20).

Se a sucessão de alterações legislativas de que o ensino primário superior é objecto a partir de 1919 indicia a existência de disfuncionamentos, não é menos certo que ele estava longe de merecer o consenso dos principais interessados.

Assim, no âmbito das constantes intervenções do jornal operário A Batalha nas questões de instrução pública - traduzidas em posições críticas sobre a situação do ensino, no apoio ao movimento sindical docente, em reivindicações pe-

(19) Dados estatísticos recolhidos em José Salvado Sampaio, ob. cit., pp. 49-50. É interessante constatar que, em 1921, a percentagem de candidatos do sexo masculino era de 47,6 . Contudo, em 1923, passa a ser de $56,6 \%$. Este facto parece denunciar uma revalorização social das escolas primárias superiores.

(M) Idem, p. 51. 
dagógicas, em iniciativas associativas de promoção cultural, avultando entre elas a Universidade Popular Portuguesa, e em abundantes artigos sobre os progressos do ensino popular na União Soviética - o ensino primário superior é incidentalmente referido em 1921. O n. ${ }^{\circ} 900$ de A Batalha pronuncia-se, por um lado, contra o possível encerramento de escolas a pretexto da necessidade de redução das despesas públicas mas no n. $^{\circ} 903$ defende a reforma desse grau de ensino, num artigo intitulado As escolas primárias superiores portuguesas - como estão funcionando não prestam (21).

A ideia de uma reforma global do sistema de ensino lavrava a fundo nos meios operários e intelectuais. As associações profissionais docentes, o movimento operário, os teóricos do movimento da "escola nova», entre os quais se destacavam António Sérgio e Faria de Vasconcelos (este último colaborando estreitamente com as organizações sindicais), a Sociedade de Estudos Pedagógicos e outros centros não-estatais voltados para a inovação educacional tomam parte activa numa campanha que, todavia, estava longe de se caracterizar pela unanimidade.

\section{A participação de António Sérgio na reforma de João Camoesas}

A reflexão sobre as questões educacionais e pedagógicas tem desde cedo um lugar central na vida e na obra de António Sérgio $\left({ }^{22}\right)$.

Todavia, Sérgio não exercerá a actividade docente a não ser em curtíssimos períodos da sua vida. Em 1911, pouco depois de se ter demitido da Marinha portuguesa, sabemos das suas infrutíferas tentativas no sentido de criar em Lisboa uma Universidade Popular ligada, como as do Porto e de Coimbra, à Renascença Portuguesa. Por essa mesma época terá pensado em concorrer a um lugar de professor de Geografia, possivelmente na Faculdade de Letras de Lisboa, mas o concurso foi adiado e acabou por se não efectivar. Mais tarde, em 1917, animaria em casa de Fortunato Abecassis um pequeno núcleo

(21) Sobre o diário A Batalha ver Jacinto Baptista, Surgindo vem ao longe a nova aurora... Para a história do diário sindicalista A Batalha. 1919-1927, Lisboa, Livraria Bertrand, s.d. (1977).

$\left.C^{2}\right)$ O pensamento pedagógico de Sérgio forneceu ensejo a dois estudos: Rui Grácio, Educação e Educadores, Lisboa, Livros Horizonte, e Rogério Fernandes, A Pedagogia Portuguesa Contemporânea, Lisboa, Instituto de Cultura Portuguesa, s.d. (1979), pp. 43 e ss. 
de educação infantil ou primária, após o que ele próprio fundou uma escola desse tipo. Sabemos que as suas relações com os discípulos eram excelentes (23). Em 1921-1922, período em que lançou no Brasil uma empresa editora com Alvaro Pinto, responsável pela publicação de A Águia no outro lado do Atlântico, Sérgio revelará, referindo-se com amargura aos próceres da 1. ${ }^{\mathrm{a}}$ República e, na ocorrência, a Agostinho Fortes, outra frustrada tentativa de ingresso no ensino superior. "Soube com efeito que a cadeira de Pedagogia da Universidade de Lisboa, confidenciará em carta a Raul Proença, que o Adolfo Coelho propôs em conselho do Curso Superior de Letras que fosse confiada a mim, e que o Queiroz Velloso reclamou para a sua pessoa, veio a parar às mãos competentíssimas do dito [Agostinho Fortes]. Seja feita a vontade de quem manda!» (24).

Essa limitadíssima experiência de ensino não seria, contudo, impeditiva de larga actividade teórica sobre questões educacionais. Tendo estagiado em Genebra com Claparède, com quem viria a estabelecer relações de amizade extensivas a Ferrière (25), Sérgio é um dos mais persistentes divulgadores, entre nós, das correntes pedagógicas da escola activa (26).

A importância atribuída pelo autor dos Ensaios aos problemas educativos decorre do carácter verdadeiramente reformista da sua ideologia social e económica. No seu entender, seria através da educação - concretamente do jardim-escola, da escola-oficina, da universidade popular, da revista, da conferência, do debate, etc. - que se operaria entre nós o que chama revolução construtiva, o contrário, em suma, do regime social-económico vigente na $1{ }^{a}{ }^{a}$ República. Deste ponto de vista, seria «a escola trabalhando, e não na praça pública a barricada, quem pode vir a fundar a verdadeira democracia» $\left({ }^{27}\right)$.

A «ilusão revolucionária» de Sérgio levá-lo-ia, por um lado, a conferir à educação um poder determinante de reestru-

(") Rogério Fernandes, ob. cit., p. 44 e p. 151.

(M) Biblioteca Nacional. Reservados. Espólios. El. Caixa 31, Doc. $^{\circ}$ n. ${ }^{\circ}$ 74. Temos noticia de que Sérgio terá sido, muito mais tarde, professor do ensino secundário liceal particular na extinta Escola (ou Colégio) de Pedro Nunes, sita na Rua Ferreira Borges, a Campo de Ourique.

$\left({ }^{25}\right)$ Ver o trabalho de António Nóvoa, Adolphe Ferrière et le Mouvement de VÉducation Nouvelle au Portugal. 1920-1935, Université de Genève, FAPS, 1981-1982.

(*) Ver a esse respeito, Rogério Fernandes, ob. cit., p. 83 e p. 96. Consulte-se, ainda, Cartas de Antonio Sérgio a Álvaro Pinto, Lisboa, Ocidente, 1972, p. 35.

?) «Prefácio a O Método Montessori de Luisa Sérgio», A Águia, (42) Junho, 1915, p. 255. 
turação social e, por outro lado, a confiar a uma pretensa elite dirigente o papel de vanguarda.

Esta posição de classe, característica da cleresia portuguesa mais avançada e de que o Grupo «Seara Nova» foi, a partir de 1921, o núcleo actuante, conduziria Sérgio frequentemente a posições de distanciação e de isolamento em relação ao movimento operário e popular.

Como exerceria a educação essa função social em que Sérgio via o motor do progresso?

Submetendo a educação portuguesa a uma crítica certeira, ainda hoje válida em aspectos essenciais, Sérgio queria ver nela, contudo, o lugar de congraçamento das classes sociais antagonistas. "Só a escola essencialmente activa, para ricos e para pobres, pode fundir todas as classes numa comunidade humana superior, afirmará nos Ensaios: por um lado, elevando o trabalho à dignidade de uma concepção geral e filosófica; por outro, banindo o dualismo pedagógico que divorcia as classes desde a escola: em baixo a simples instrução do $a b c$, mecânica e utilitária, para o homem do povo; em cima, essa etérea educação falsamente aristocrática, meramente especulativa e sem ligação com o trabalho, que se dá, ainda hoje, às classes dirigentes da sociedade». Neste caminho, Sérgio chegará mesmo a defender posições de colaboração de classes. "É absolutamente necessário, sentenciará, unir as classes sociais dentro da escola, impregnando todas elas de uma mentalidade cooperativista». A reunião do intelectual, do pequeno-burguês e do operário «na mesma escola de educação activa» (entendida como uma «mesma comunidade de trabalho») daria «um agente de realização plena do ressurgimento português» $\left({ }^{28}\right)$.

Sem atender, precisamente, a que a abolição do «dualismo pedagógico» pressupunha a abolição do «dualismo social», isto é, uma sociedade a caminho do Socialismo, Sérgio vai bater-se utópicamente, até ao fim da vida, pelo que chamou «a escola do trabalho». Nenhum outro teorista enquadrado no democratismo burguês irá tão longe, e com tanto ardor, na defesa de um sistema de ensino baseado no trabalho e na prática, e portanto na união intrínseca do trabalho intelectual e do trabalho manual. O trabalho seria, para Sérgio, o eixo fundamental de toda a acção educativa, «um instrumento de todo

$\left.C^{28}\right)$ «Paideia (Sugestões e Conselhos de há mais de trinta anos)», in Ensaios, VIII, Ed. Sa da Costa, pp. 226-227, e «Divagações pedagógicas», idem, II, p. 187. (Texto datado 1923). 
o progresso de consciência», o mais perfeito instrumento de humanização $\left({ }^{29}\right)$.

No âmago da teoria da «escola única do trabalho», isto é, da substituição da escola «para lustrar» pela escola «para produzir» $\left({ }^{30}\right)$, Sérgio colocava o que apelidou ensino de continuação.

Esta via de ensino correspondia, no essencial, ao ensino primário superior criado pelo Poder republicano em 1911 mas só muito mais tarde concretizado. De facto, em 1918, Sérgio delinearia o seu projecto de sistema de ensino com base num «tronco comum» que compreenderia a escola infantil (dos 3 aos 7 anos) e a escola primária. A partir dos 12 anos, o sistema, segundo a terminologia de Sérgio, bifurcaria pelo ensino primário superior e de continuação, até aos 18 anos, e por uma via paralela de ensino secundário por meio da qual se ingressaria na Universidade $\left({ }^{31}\right)$.

Firmando-se numa escola primária elementar que já contaria componentes práticas, o ensino primário de continuação destinar-se-ia aos jovens que se não destinassem à Universidade e que, na opinião de Sérgio, deveriam constituir o maior número. Essas escolas seriam frequentadas dos 14 aos 18 anos, cumulativamente com o exercício de uma aetividade profissional de que o período dos 12 aos 14 anos parecia constituir a fase preparatória $\left({ }^{32}\right)$.

$\mathrm{O}$ ensino de continuação abrangeria instrução prática e teórica em oficinas, laboratórios e granjas escolares, conferida por profissionais especializados no ofício a que $\mathrm{o}^{*}$ aluno aspirasse e sob os auspícios de uma associação de classe.

Além dessa formação prático-profissional, pretendia Sérgio que o currículo incluísse instrução comercial, estudos sociais, cultura literária e artística, bem como educação cívica teórica e prática, ministrada esta última em «corporações de self-government» (33).

Conforme esclarecerá mais tarde, mas é desde logo visível, o ensino primário superior ou de continuação destina-

\section{p. 11.}

${ }^{(20)}$ «Prefácio a Henri Le Chatelier», Indústria e Ciência, Lisboa, sob a ideia directriz do trabalho produtivo», in Pela Grei, (3-4), 1918, p. 219.

(31) O Ensino como factor de ressurgimento nacional, Porto, Renascença Portuguesa, s.d. (1918), p. 40. De notar que Sérgio defendia igualmente uma reforma profunda do ensino secundário.

${ }^{(32)}$ Sérgio falara, nesta época, dos «sandwich courses», isto é, de alternâncias «estudo-trabalho». $\mathrm{C}^{33}$ ) Idem, p. 41. 
va-se a criar quadros para o sistema produtivo e a desviar do ensino superior a grande massa de estudantes que concluia a escola primária ( $\left.{ }^{34}\right)$.

A 23 de Maio de 1919, ao iniciar-se a publicação do diário operário A Batalha, António Sérgio criticará, uma vez mais, a escola portuguesa. $O$ sistema de ensino, diria nessa altura, «serve para fabricar parasitas». E acrescentaria: «Os seus fins reais são os seguintes: sustentar professores, editores e autores de compêndios e de cartilhas; preparar os filhos dos burgueses para empregados públicos, destruindo-lhes os dons de iniciativa; preparar os filhos do povo para vadios».

Reafirmando que «a ideia dominante da reforma (da escola)» deve ser a do trabalho produtivo, Sérgio defenderá nas suas linhas gerais um esquema de reorganização do ensino «própria da Democracia social dos novos tempos», na base de um plano geral de reestruturação económica $\left({ }^{85}\right)$.

Para a efectivação dessa reforma, pretendia Sérgio se desencadeasse um amplo movimento de opinião pública. Para ele concitava A Batalha, sem que o seu entrevistador, aliás, repelisse o convite.

Não obstante Sérgio ambicionasse uma reestruturação global da sociedade portuguesa, nos limites do social-democratismo, de que a reforma da educação seria uma das componentes, não desdenhava as oportunidades de intervenção na esfera do Estado, embora sob condições. Nomeado em 1918 para integrar uma Comissão encarregada da reforma do ensino normal, pretendeu que ela ultrapassasse o plano da mera acção legislativa. Conjuntamente com Celestino da Costa, elabora, nessa ocasião, o projecto de uma Junta cuja função seria «criar focos para a reforma da cultura em Portugal», inspirando-se numa experiência espanhola contemporânea. O projecto não vai adiante pelo facto de Sérgio ter pedido a exoneração, persuadido de que, atenta a composição do grupo, nada de positivo poderia resultar do seu trabalho (36).

O período que decorre até 1923-1924 marca um notável ascenso da sua actividade no sentido da reforma do sistema de ensino. Esta acção inseria-se na linha que the é peculiar, exprimindo-se em propostas globais de reestruturação da vida pública. Sob esse aspecto, salienta-se o "Apelo à Nação», publicado na Seara Nova. Assinado por Sérgio, Afonso Duarte, Ferreira de Macedo, António Augusto Gonçalves, Bazílio Teles,

$\left.{ }^{34}\right)$ Rogério Fernandes, ob. cit., pp. 88-89.

(35) Cf. Jacinto Baptista, ob. cit., pp. 179-181. Estas declarações não deixariam de suscitar polémica. Ver A Batalha, n. ${ }^{\circ} 13$ e n. 17.

$\left.C^{36}\right)$ Rogério Fernandes, ob. cit., p. 95. 
Faria de Vasconcelos, Augusto Casimiro, Carlos Selvagem, Ezequiel de Campos, etc., esse documento alinha, como «medidas imediatas, compatíveis com os actuais recursos do país», para o sector da educação, o que poderia considerar-se, aproximadamente, uma súmula do projecto de reforma subscrito mais tarde por João Camoesas.

Com efeito, as 11 medidas preconizadas abrangem a reorganização das escolas normais e seus programas, com a criação de quatro escolas modelos - infantil, primária, secundária e de continuação - ; remodelação dos programas de instrução primária e secundária, desenvolvimento do escotismo e da educação cívica pelo self-government; criação de uma Junta da Educação, com «liberdade de movimentos» e exercendo funções inspectivas, de avaliação pedagógica e executivas; fomento da educação cívica e apoio, no mesmo sentido, à acção das municipalidades; criação do "Tesouro da Educação Nacional» administrado pela Junta; adaptação da escola primária rural ao meio ambiente; criação de uma Junta de Orientação dos Estudos; criação de uma Residência de Estudantes e de consultórios de orientação profissional; criação de escolas de trabalhos manuais, anexas a grupos de escolas, e de museus pedagógicos; e, finalmente, criação da escola de continuação, «com estudos gerais e técnicos, que substituirá a secundária e superior para os indivíduos que não devem destinar-se à alta cultura intelectual» $\left({ }^{37}\right)$.

É patente a influência das ideias pedagógicas de Sérgio em muitos dos aspectos centrais deste programa, designadamente quanto ao ensino de continuação, à reforma das escolas normais, à criação da Junta de Educação e da Junta de Orientação dos Estudos, independentes do Poder político. A sua acção no interior da União Cívica era, de resto, determinante. Assim, dirigindo-se a Proença, e em referência a uma personagem cuja identificação não lográmos, Sérgio caracteriza a orientaçã̃o da União Cívica, pondo particular ênfase no que parecia ser um triunfo das suas concepções em matéria pedagógica e económica. «Rogo-lhe q. diga a este homem, (pediria), entre tudo mais q. lhe ocorrer, que:

1. Ele está ainda na fase romântica e bárbara de q. só se regeneram sociedades com actos revolucionários teatrais: plebes com chuços, berraria, dinamite, etc. Nós, pelo contrário, acreditamos na acção pacífica e persistente das ideias claras propagadas por uma elite.

(3T) Seara Nova (21), Março, 1923, p. 134. 
$2^{\circ}$ Que, se a União Cívica lhe parece morta, é porque ele só sabe ver as manifestações materiais. As ideas da União Cívica estão mostrando, pelo contrário, uma vitalidade enorme, como o provam:

a reforma da inst. 0 0

a criação da Junta da Educação

a reforma agrária q. o ministro da Agricultura propõe ao Parlamento» ( $\left.{ }^{3 S}\right)$.

A projectada reforma de ensino de João Camoesas, datada de 1923, permitir-lhe-ia, em seguida, tentar fazer passar à prática algumas das suas concepções.

A participação do Grupo da «Seara Nova» na elaboração do projecto de Camoesas tem na pessoa de Faria de Vasconcelos e na de António Sérgio os dois elementos de maior projecção.

Álgumas cartas de Sérgio permitem divisar, contudo, os limites, restrições e conflitos de que a sua participação pessoal se acompanhou. A crer na versão que apresenta dos factos, enquanto Faria de Vasconcelos tenderia a aceitar passivamente as orientações do ministro, Sérgio procuraria, de dentro, fazê-las inflectir no sentido que julgava mais consentâneo com o rumo progressista da educação. Assim, confidenciaria a Raul Proença numa carta inédita: «O Faria, de cócoras diante do ministro e hipnotizado por S. Ex. ${ }^{\text {a }}$, não me responde às cartas, nas quais lhe fazia com inteira e fraternal sinceridade os mais gentis oferecimentos. As relações oficiais já as cortou comigo; não sei se quer cortar também as particulares. Já lhe declarei q. combateria pela Reforma como guerrilheiro independente das forças regulares e dos seus chefes; mas há problemas da Junta de Educação, estranhos, pois, a Sua Excelência - o - Ministro, que eu precisava de combinar com ele. Mas não me responde por mais cartas q. eu the escreva, e não sei se me cumpre proceder, também aí, como se ele não existisse»» $\left({ }^{39}\right)$.

Noutra carta, voltaria a queixar-se a Raul Proença da passividade de Faria de Vasconcelos, que diz «enfeitiçado» pelo ministro. E desabafa: «Em vez de se aliar comigo, para impormos sempre ao político as boas doutrinas (o q. verifiquei ser facílimo) deixou de pensar pela própria cabeça, e cede, apaga-se, aniquila-se, ao menor gesto de capricho de S. Ex. ${ }^{\mathrm{a}} \gg\left({ }^{40}\right)$.

('S) Biblioteca Nacional..., cit., doc. ${ }^{\circ}$ n. ${ }^{\circ} 143$.

(36) Idem, doc. ${ }^{\circ}$ n. ${ }^{\circ} 97$.

(40) Idem, doc. ${ }^{\circ} .^{\circ} 60$. 
A proposta de lei da Reforma da Educação é apresentada pelo ministro João Camoesas ao Parlamento com data de 21 de Junho de 1923.

Projecto notabilíssimo, talvez o mais notável na história da nossa instrução pública, abria por uma vigorosa análise crítica do sistema de ensino.

A necessidade de transformação do «sistema de instrução pública» português era justificada pelas novas realidades emergentes da Guerra, em paralelo com o movimento de reforma educacional em curso nos demais países europeus.

Em primeiro lugar, salientava-se que, em matéria de ensino, o país não lograva «resultados correspondentes aos seus esforços em dinheiro e homens» ( $\left.{ }^{41}\right)$. Apontavam-se, em seguida as deficiências fundamentais dos diferentes patamares do sistema e das diversas actividades por ele compreendidas.

A directriz fundamental da reforma corresponde, no essencial, às concepções defendidas por Sérgio. Essa directriz, subjacente às críticas tanto quanto às disposições inovadoras, tem implícito o reconhecimento da necessidade imperativa da criação do que chamava a «escola do trabalho», em contraste com a orientação prevalecente. $\mathrm{O}$ texto do projecto de lei reproduz quase fielmente neste ponto o que Sérgio deixara estampado em $O$ Ensino como factor cie ressurgimento nacional. "Quando se formula o problema da organização do ensino em termos e em função das espécies e classes de homens adestrados de que o país necessita. escreve-se na secção n. ${ }^{\circ} 12$ da proposta, nota-se a flagrante inversão da proporcionalidade natural das profissões e categorias. Gasta-se com o ensino secundário e superior "liberar quase $6000000 \$$ e não chega a metade o que se despen.de com todos os graus, elementar, complementar e superior do ensino técnico (agrícola, colonial, comercial, industrial e profissional). Quer dizer, tem-se procedido como se o nosso exército social de trabalho não devesse compor-se na sua grande maioria senão de generais e oficiais de uma só arma (as profissões chamadas «liberais»), que logicamente deve ser a menos numerosa, e pudesse dispor de um número insignificante de subalternos e soldados qualificados de todas as outras (as profissões «usuais» da agricultura, da indústria e do comércio)». E rematava-se: «Pelo nosso sistema escolar a grande maioria da juventude é desgra-

(41) Ministério da Instrução Pública. Pteforma da Educação. Proposta de lei. (Separata do "Diário do Governo" de 2 de Julho de 1922). Para a distribuição gratuita, Lisboa, Imprensa Nacional, 1923, p. 3. 
çadamente solicitada e dirigida para as profissões liberais, com prejuízo manifesto da economia e do equilíbrio social e político do país» (42).

Feito o balanço da situação, a proposta apresentada pelo ministro João Camoesas continha um conjunto de 24 bases que implicavam a completa reestruturação da escola portuguesa.

A montante do sistema situava-se o jardim-de-infância, que tenderia para a obrigatoriedade, após o que se passava à escola primária obrigatória, de dois graus (dos 7 aos 12 anos de idade). A partir daí o sistema bifurcaria entre o curso geral dos liceus e as escolas elementares técnicas (prevendo-se a colocação, sob a responsabilidade do futuro Ministério da Educação Nacional, de todos os organismos de educação existentes noutros Ministérios).

Entre o curso geral dos liceus e as escolas elementares técnicas não se estabelecia qualquer trânsito horizontal. O primeiro desses cursos daria acesso ao curso especial dos liceus (correspondente a um complementar), ao passo que as segundas permitiriam o ingresso em escolas complementares técnicas ou em escolas profissionais.

Neste ponto, porém, a estrutura cruzava-se: do curso geral dos liceus poder-se-ia transitar às escolas complementares técnicas, e das elementares técnicas ao curso especial dos liceus.

Quanto ao acesso ao ensino superior e universitário, ele era possível a partir de ambas as vias, existindo em paralelo os cursos populares superiores e as Universidades populares, aos quais se teria acesso a partir das escolas elementares ou complementares técnicas, ou das escolas profissionais.

As escolas primárias superiores desapareciam deste esquema. Criticadas no preâmbulo por não corresponderem à sua finalidade e «por assumirem carácter de organismos liceais», fundir-se-iam com as escolas de artes e ofícios, aulas comerciais, escolas preparatórias de comércio e indústria, escolas industriais e comerciais, e com as escolas elementares agrícolas. Em lugar de todos estes estabelecimentos surgiriam Escolas Técnicas Elementares de vários tipos: agrícola, comercial, doméstico, industrial e marítimo. Preparariam para o ingresso directo na vida activa ou para a frequência das Escolas Complementares correspondentes, em que seriam convertidos os liceus femininos de Lisboa, Porto e Coimbra ( $\left.{ }^{43}\right)$.

(42) Idem, p. 11.

(43) Idem, p. 9 e pp. $25-26$ e p. 28. 
Elaborada a proposta sob a responsabilidade política do ministro João Camoesas, o processo de negociação exigido pela sua aprovação e aplicação pretendera-se que fosse amplamente participado. Conforme também se declara no preâmbulo, procedera-se a um largo inquérito entre o professorado, cuja intensidade de resposta, notava-se de passagem, deixara a desejar, ouvira-se o maior número possível «das individualidades eminentes do ambiente pedagógico nacional» e, finalmente, obtivera-se «a colaboração de homens experimentados, com um passado profissional que os eleva ao plano superior das verdadeiras autoridades» $\left({ }^{44}\right)$.

$\mathrm{Na}$ mesma perspectiva, ambicionava-se igualmente que a proposta de lei desse origem a um intenso debate nacional. Assim, e ainda no preâmbulo, os ministros da Instrução e das Finanças, ambos signatários, comprometiam-se a procurar promover «por todos os meios adequados (e fiéis aos princípios da verdadeira democracia que animam todo este trabalho) o conhecimento e a análise da presente proposta, uma intensa agitação de ideias, uma viva concorrência de aspirações, um proveitoso, elevado e tolerante debate de consciências e inteligências que prepare e anime a discussão desta matéria no Congresso da República e o possa encaminhar seguramente às deliberações frutuosas e patrióticas» $\left({ }^{45}\right)$.

É neste plano que se insere a publicação da Proposta de Lei em separata do Diário do Governo de 2 de Julho de 1923 , com vista à sua distribuição gratuita.

Sérgio parece ter tido uma intervenção decisiva quanto ao desbloqueamento do texto na Imprensa Nacional e ao arranque do debate, não obstante o seu desacordo em relação a certas disposições concretas da reforma e às presumíveis complacências de Faria de Vasconcelos para com as ideias do ministro. Outra carta inédita de Sérgio a Raul Proença aflora ambos os pontos: «O Camoesas está amuado comigo. Muito correcto $\left({ }^{46}\right)$, mas dá a entender q. eu não fui bastante gentil para com ele. Coisas em que me mete o nosso amigo Faria, com as suas infinitas condescendências e molezas em relação ao Poder e às Forças Supremas do Estado. De aí resulta q. eu faço contraste, e me vejo obrigado por vezes a praticar reacções, em favor da obra, como quando tive q. ir à Imprensa Nacional pôr e dispor. Já se murmurava do ministro, q. não fazia conhecer largamente a reforma, como propalavra.

(44) Idem, pp. 16-17.

(45) Idem, p. 17.

(46) Sérgio escrevera: «amável» mas riscou e substituiu a 
metera; fui eu q. os salvei de fazer tolice: e ainda por cima me pintam de tirano. Já sei q. vão cair sobre mim nenhuma das glórias (no que me estou nas tintas) e todas as antipatias da obra. O Camara Reys já atribuiu ao Faria todas as tendências sociais da reforma, a q. o Faria não deu consideração alguma nos seus primeiros planos (ensino de continuação, etc.) e q. mesmo assim ficaram menos desenvolvidos do q. eu propus na conferência da União Cívica. Paciência» ( $\left.{ }^{47}\right)$.

(4T) Biblioteca Nacional..., cit., doc. ${ }^{\circ}$ n. ${ }^{\circ}$ 155. Em duas cartas para Afonso Lopes Vieira, desta mesma época, Sérgio alude às suas divergências com o ministro e aos limites que se auto-impusera à sua colaboração. Redarguindo ao poeta, que decerto o censurara por essa aproximação, diz o nosso ensaísta: «Sou o Pafnúncio da Tha'ís-Camoesas. Também V., querido amigo, foi o Pafnúncio, ou coisa q. o valha, do João de Deus Ramos - tão jacobino como o Camoesas, mas mais desorientado (muito mais!) em questão de pedagogias. Com uma diferença: o Camoesas tem estado, desde o princípio, amuado comigo. Copio-lhe um trecho da sua última carta: «Não sou dado ao ressentimento. Costumei-me a não me indispor nem conflituar sem reflectir. E um mínimo de reflexão facilmente me conduz a não sacrificar o êxito de uma obra de alto interesse nacional à satisfação de quaisquer preocupações pessoais, mesmo justas.» "Como vê, o Camoesas não me acha simpático; supõe ter justas razões de ressentimento contra mim. Mas não importa. Não colaboramos por simpatia ou por amizade, nós. Ambos, porem, nos escravizamos à obra. Da minha parte, o sacrifício é facílimo, porque realmente não existe. Da parte dele, Ministro, Poder, superior hierárquico, é dificílimo. E aí temos de reconhecer q. o Camoesas é nobre. Colaboro com Thaïs, sem amar Thaïs; o Pafnúncio -Afonso amou a sua». E noutra carta, referindo-se provavelmente ao afastamento de Camoesas da orientação política dominante nos partidos burgueses da 1.a República: «Sobre a conversão do Camoesas não tenho ilusões, e por isso me conservo a boa distância: basta-me q. ele seja o instrumento de uma obra fecunda; não é a alma de s. ex.a q. eu quero salvar, mas as de outros, por intermédio da vaidade dele, que sonha armar em grande homem à custa do Faria de Vasconcelos e da minha pessoa». («Duas cartas inéditas de António Sérgio para Afonso Lopes Vieira» apresentadas por Rogério Fernandes, in Colóquio-Letras, (46), Lisboa, 1978, pp. 60-61, p. 63 e p. 65).

Noutro documento existente no já citado espólio da Biblioteca Nacional, Sérgio atribuía certos desabafos à irritação causada pela falta de resposta de Camoesas e de Faria de Vasconcelos às suas cartas. É possível que esse colorido pessoal também interferisse mas as razões de fundo da tensão eram obviamente outras.

Com efeito, o conflito Camoesas-Faria de Vasconcelos-Sérgio tem razoes políticas que tencionamos aprofundar em estudo ulterior sobre este projecto de reforma do ensino. As acusações de «esquerdismo» procedentes das facçôes mais conservadoras do republicanismo estão talvez na origem da minimização, feita por Camoesas, da colaboração de Faria de Vasconcelos e do «defensismo» deste último pedagogo, tão acerbamente criticado pelo autor das Cartas de Problemática. Por outro lado, a reprovação do Grupo «Seara Nova» dos processos da governação republicana teriam levado, neste caso con- 
creto, o ministro Camoesas a diminuir o mais possível a participação da gente da Seara no seu projecto pessoal.

Uma carta inédita de Sérgio a Ferreira de Macedo, amavelmente cedida do seu espólio pelos Filhos do grande impulsionador da Universidade Popular Portuguesa, refere a existência de uma tomada de posição de Alves dos Santos e da réplica de Sérgio, que serão objecto de análise no nosso estudo supracitado.

A carta a Ferreira de Macedo data, segundo tudo indica, de 1923, provavelmente do Verão.

Repare-se que ela transcreve da carta de João Camoesas dirigida a Sérgio um trecho mais extenso do que aquele que Sérgio dera a conhecer a Afonso Lipes Vieira:

\section{Escola Agrícola de Bemcanta Coimbra Sexta-feira}

Querido amigo. Como tem passado? E como vão esses planos de trabalhos pessoais? Na mesma? modificou-os? preparou a execução? Estou curioso de saber quais sejam.

Camoesas entrou francamente no caminho de se mostrar amuado comigo e de nos comer a cabeça aos dois - a mim e ao Faria. No Congresso de Leiria disse o seguinte, q. copio do Século:

«Elogiou os seus colaboradores srs. Faria de Vasconcelos e Teófilo Júnior, afirmando q. nenhum dos três diz ser sua a reforma, porque é da nação».

Esta idea peregrina de dizer q. aquilo foi feito pela nação é uma esperteza muito linda para roubar o Faria do reconhecimento do $q$. The deve, e distribuir a coisa igualmente pelos três: Faria, ele Camoesas Ipalavra escrita sobre outra, ilegível, e seguida de uma palavra riscada],.. e Teófilo Júnior. «Nenhum dos três diz ser sua a reforma». E impagável. O discurso marca, além disso, o rompimento comigo. Até aqui s. ex. ${ }^{a}$ costumava incluir-me na lista dos seus colaboradores - com o Faria... e o Teófilo: Dizia, é certo, que só no jim (o q. é mentira), mas chegou a declarar q. esse fim fora a revisão geral da obra. Adiante. Percebe que, em si, nada me importa o q. diga de mim o Camoesas; não é de ali q. há-de vir o juizo definitivo sobre o mérito ou demérito dos meus trabalhos; mas tudo isto importa como índice da atitude do homem: insinuar q., grande [riscado: homem] como ele é, um Faria não o ajudou mais do q. um Teófilo Júnior. Diante dele, Himalaia, essas duas colinas teem a mesma altura. Ora, é esta preocupação de vaidade, de comer o Faria (e a mim) q. entristece, sem desanimar. Vou-lhe contar uma história. Um dia um amigo meu (J. Bensaude) falava a um amigo e correlegionário do Camoesas (Lago Cerqueira). Incidiu a palestra, em certa altura, sobre a reforma. $O$ meu amigo pronunciou o nome do Faria (q. ele conhece por meu intermédio) e o meu. E o Lago Cerqueira: «Qual Faria! Qual Sérgio! Esses cavalheiros não fizeram nada, sei-o eu; auxiliam o ministro na propaganda. Aquilo é tudo obra do Camoesas».

Não conto ao Faria estas coisas. Para quê? Entristecia-o, sem provocar nele uma reacção de hombridade, que é o q. se quereria. Já o tenho na conta de incurável alforreca. Resigno-me. E o ministro também: quando não não chegaria a dizer o q. disse no congresso de Leiria. Não percebe aquele idiota do Camoesas q. faria uma lindíssima figura se reconhecesse 
em público, francamente, o seu papel de político, realizador, sem se enfeitar estupidamente com as penas de técnico. Que fez o Pombal (e era Pombal)? Nomeou D. Francisco de Lemos, assistido de Cenáculo, reformador da Universidade, e pronto. Publicou q. quem reformava era o técnico; ele estava ali como cabeca politica, para fazer executar os planos do sábio.

$\mathrm{E}$ tudo isto se teria evitado se o Faria, desde o princípio, se tivesse posto no seu lugar! Se tivesse compreendido q. o seu aliado natural era eu; se se tivesse unido a mim para nos apoiarmos reciprocamente nas nossas relações com o político, em vez de se pôr na esteira do político, dando-lhe sempre razão contra mim.

Ao chegar aqui, Bemcanta, escrevi ao Camoesas uma carta. Dizia-lhe q. me não pudera despedir dele na noite da conferência do Faria, véspera da minha partida, porque ele desaparecera sem eu esperar; q. me custara achar ele q. eu não correspondia bastantemente às amabilidades que ele me prodigalizara; q. se era verdade ser essa a impressão dele, tudo levaria atribuir a uma questão de temperamento pouco expansivo da minha parte, a não ser com pessoas muito íntimas, etc.; que, aliás, era eu o primeiro a reconhecer q. a familiaridade portuguesa era melhor e mais simpática do q. a minha reserva, mas q. era difícil uma pessoa contrariar o seu temperamento, etc. Esperava q. ele me respondesse q. eu fora mal informado, etc. Pois, não senhor. Respondeu-me isto:

«Muito agradeço a $\mathbf{V}$. as explicações $q$. teve a bondade de me endereçar. Estou habituado a dominar a minha sensibilidade. Também não sou dado ao ressentimento. Costumei-me, por isso, a não me indispor nem conflituar sem reflectir. E um mínimo de reflexão facilmente me conduz a não sacrificar o êxito de uma obra de alto interesse nacional à satisfação de quaisquer preocupações pessoais, mesmo justas. Não quero deixar de agradecer ainda a $V$. a disposição em $q$. continua de ajudar a implantação da reforma. Até Outubro aguentaremos o q. está feito, intensificando então os trabalhos. Fácil me tem sido, com prazer o registo, aguentar a altura moral com q. desde o início coloquei esta obra. Espero q. conseguirei mantê-la com a mesma facilidade. Reiterando os meus agradecimentos, etc.»

Que diz a isto? Se se não tratasse de uma obra q. está muito acima das impulsões pessoais, mandava-o já pintar macacos. Mas não pode ser. Escrevi ao Faria, q. me dissesse quais são os crimes concretos praticados pela minha pessoa. Não passar os meus dias no gabinete ministerial e respectiva antecâmara? Não me respondeu. Não sei se reparou q. na minha resposta ao Alves dos Santos eu me pus bem subalterno em relação ao Faria, lhe dei a ele todas as honras da reforma. Pois [três palavras riscadas] o Faria queria responder dizendo q. deixava de lado o ataque pessoal, e mais nada, como q. me reprovava a réplica, q. eu tomara à minha conta, a essa parte mais desagradável e difícil de tratar. Fiz-lhe notar q. lhe não ficava bem a ele deixar de dizer $q$. não respondia a essa parte porque já eu me encarregara dela. Tudo isto, em si, não tem a menor importância; e tudo afinal importa muito, pela péssima atitude de espírito q. denuncia.

Cumprimentos nossos a V.V.

Am. e admor.

A. S. 
Também no debate de que se acompanha a divulgação da proposta, o Grupo da «Seara Nova» e, em especial, António Sérgio tiveram activa intervenção.

Com efeito, o n. ${ }^{\circ} 25$ da Seara Nova, correspondente a Julho de 1923, insere vários materiais relativos à proposta e à sua discussão pública.

Em primeiro lugar, um artigo de Jaime Cortesão, intitulado "A Reforma da Educação», em que a Seara Nova era vinculada ao projecto apresentado por Camoesas, dada a concordância dos seus traços essenciais com o programa do Grupo e com o da União Cívica $\left({ }^{48}\right)$.

Cortesão fazia notar, depois, que a alegada filiação da reforma no ideário seareiro não diminuía o alcance da iniciativa de Camoesas. «O ministro fez o mais e o melhor que podia fazer, escrevia, numa aparente concessão aos presumíveis pruridos do responsável pela instrução pública: chamar as competências a colaborar consigo; e compreendeu, caso raro nas esferas da governação, que a função do político é exactamente dar realidade prática às ideias reformadoras dos técnicos e dos doutrinários, e que a sua principal virtude é a capacidade de acção e o sentido das realidades e nunca esse pretenso enciclopedismo, que leva os nossos homens públicos tantas vezes a uma legiferação impertinente e estéril» ( $\left.{ }^{49}\right)$.

Aplaudindo Camoesas por ter chamado a colaborar em toda a reforma Faria de Vasconcelos e em parte dela António Sérgio, e por tê-la sujeitado em seguida a uma discussão ampla, Cortesão procedia a um balanço valorativo do projecto.

O seu núcleo mais positivo localiza-o sintomaticamente num aspecto que ele próprio diz não constituir um compromisso claro. «Não o declara nitidamente a reforma, mas a instituição do ensino elementar técnico obrigatório e o de-

\section{P.S. - Aconselhe-me sobre o q. devo fazer.}

Note-se, ainda, a intenção de Camoesas de implantar a reforma e o facto de Sérgio ter oferecido a sua colaboração nesse trabalho; e ainda, na esbatida alusão de Camoesas, no final do trecho transcrito, às palavras em que Sérgio se referia, numa nota da Seara Nova, atrás citada, à «tensão moral» necessária para executar a reforma.

(48) Seara Nova, (25), Julho, 1923, p. 11. Cortesão comentava em seguida, com humor, uma crítica publicada no Correio da Manhã (jornal, como se vê, com larga tradição de direita) em que se ${ }^{\wedge}$ descobriam no projecto feições «bolchevikistas» devido à participação que nela tivera Faria de Vasconcelos, personalidade benquista nos meios operários anarco-sindicalistas.

(49) Idem, ibidem. 
senvolvimento dado a todo o ensino técnico, - para nós a linha mais original da sua arquitectura, - propõe-se satisfazer a mais urgente das nossas necessidades, a de equilibrar as profissões dentro da economia nacional», afirma, num esbatido que marca, todavia, um certo grau de insatisfação do grupo da «Seara», liderado por António Sérgio.

Cortesão assinalava, depois, os pontos capitais do projecto em torno dos quais a sua adesão se fazia sem restrições: diferenciação da educação secundária em cinco secções, divisão dos estudos universitários em «profissionais» e de «alta cultura»; criação da Junta Nacional de Fomento das Actividades Sociais e Investigações Científicas; atenção à educação física, «descondensação» dos programas, princípio do self-government, ou seja, dos trabalhos de carácter prático e do estudo confiados à escola, concessão de bolsas de estudo no estrangeiro e contratação de professores de além-fronteiras, a democratização do ensino por intermédio da assistência escolar, a gratuitidade, obrigatoriedade e outras disposições destinadas a proteger e facilitar o ensino técnico elementar, a protecção a dar às Universidades populares e a criação de cursos sistemáticos para operários, com particular destaque para duas medidas de carácter imediato: a criação de um fundo da Educação Nacional e da Inspecção Técnica do Ensino ( $\left.{ }^{50}\right)$.

Quanto aos aspectos críticos, o articulista apontava a necessidade de a reforma ser mais explícita e ampla nos fins que se propunha. Entendia que se deveria dar mais saliência ao ensino agrícola, ao ensino colonial e às escolas de emigrantes, e sobretudo, às «medidas práticas de possível realização imediata», visto que a maior parte dos objectivos indicados só a prazo seria exequível.

Indicava, ainda, a necessidade de alargar as competências da Inspecção Técnica às Universidades e, ao mesmo tempo, de lhe restringir as funções pedagógicas em matéria de programas e normas para a elaboração de compêndios, bem como a extensão da concessão das bolsas de estudo aos estudantes pobres de todos os graus de ensino.

Finalizava Cortesão com algumas considerações de carácter táctico, no sentido de que a reforma deveria ter sido subscrita não só pelos ministros da Instrução e das Finanças mas também pelos da Agricultura, do Comércio e das Colónias. E rematava o artigo, com uma indicação bem clara das esperanças dos homens da Seara quanto ao alastramento gradual

(50) Idem, pp. 11-13. 
das suas opiniões: "A penetração das ideias da Reforma no governo fez-se, como era natural, pelo ponto de menor resistência, isto é, por onde os interesses de classes possivelmente feridos ou chocados são menores. Esperemos que daí se alargue até que um grupo de homens, partidários ou não, possuídos tanto da visão clara das necessidades nacionais, como de coragem moral, lance ombros à execução de um plano geral, tanto pelos lados de menor resistência, como naqueles onde o choque de interesses há-de atear o incêndio das piores paixões» ( $\left.{ }^{51}\right)$.

Como se vê, o artigo de Cortesão, exprimindo obviamente a opinião «oficiosa» do Grupo «Seara Nova», apenas aparece restritivo, em relação ao conteúdo da reforma, na questão das escolas técnicas elementares e na falta de inserção destas no quadro da escolaridade obrigatória.

Sérgio, por seu turno, inseria uma nota no mesmo número da revista, chamando a atenção para os debates levados a cabo na «assembleia dos professores primários», bem como para o questionário de 18 pontos publicado na página seguinte e que acompanhava os exemplares da proposta submetida à discussão pública. Considerava, nessa nota, como «muito provável» o triunfo «da ideia da reforma», se, acrescentava numa possível alusão a Camoesas e Faria de Vasconcelos, "os superiores timoneiros das fainas executivas mantiverem o grau de tensão moral indispensável a uma obra destas» $\left({ }^{52}\right)$.

Entretanto, porém, Sérgio continuava a pugnar, por debaixo da capa, pelo ensino de continuação, prejudicado, na reforma, pela concepção das escolas técnicas elementares. Numa carta, também inédita, a Raul Proença, junto de quem já se lamentara pelo abandono, ou menosprezo, do ensino de continuação, dizia: «peço-lhe que não deixe de responder ao questionário da reforma; e, se estiver de acordo, proponha q. as escolas q. no projecto se denominaram técnicas elementares e complementares recebam o seu nome verdadeiro de escolas de continuação. Chamar-lhes escolas técnicas, como o M. quer, é tolice; mas o F. não teve a insistência necessária para o convencer» $\left({ }^{53}\right)$.

Do vasto acervo de ideias e objectivos explanados no projecto subscrito por João Camoesas, e que perfilhava no essencial, é visível que Sérgio selecciona alguns pontos limitados.

(51) Idem, p. 13.

C' Idem, p. 19.

(53) Biblioteca Nacional..., cit., doc. n. ${ }^{\circ} 69$. 
Assim, na conferência proferida a 25 desse mesmo mês de Julho de 1923 na Sociedade de Geografia e cujo texto viria a ser dedicado a Câmara Reys, defende a reforma por seis motivos fundamentais.

O primeiro, por ser «sincera e efectiva», isto é, por prevenir «que só gradual, e lenta, e experimentalmente, se poderá fazer a reformação» ( $\left.{ }^{54}\right)$. Esta leitura que parece todavia pessoalíssima, correspondia no fundo à efectivação de dois elementos estratégicos da sua própria concepção de «reforma do ensino»: criação de escolas-modelos, com pessoal seleccionado, que Sérgio não indica a que grau de ensino pertenceriam, escolas normais e bolsas de estudo destinadas à preparação de professores no estrangeiro ( ${ }^{55}$ ).

Em seguida, criação de «um conselho de homens idóneos, imparciais, apontados pelos que se temem da imoralidade na execução, e encarregado de policiar, sob esse aspecto, o procedimento dos executantes» $\left({ }^{56}\right)$.

Esta razão central, a que se adicionavam o carácter sistemático e coordenado da reforma, o seu acordo com os princípios da moderna pedagogia, as suas virtualidades em ordem à formação de «uma elite para as necessidades do nosso país», a sua índole democrática, e bem assim a sua coordenação com as demais reformas necessárias, justificava o compromisso de Sérgio.

\section{Sérgio no Ministério du Instrução}

O ingresso de Sérgio como ministro da Instrução Pública no governo presidido por Álvaro de Castro fora precedido de uma «Carta aberta dirigida a S. Ex. ${ }^{\text {a }}$ o Presidente da República» pelo Grupo «Seara Nova» $\left({ }^{57}\right)$. Esse documento, de excepcional importância política, contém desenvolvida referência ao «problema pedagógico».

A marca de Sérgio é visível no texto. Comprovam-no, além de outras concordâncias, as alusões indirectas à sua atitude pessoal em relação à reforma de João Camoesas. «É costume de portugueses insistir no que nos separa, e não naquilo que os pode unir: nos pretextos de antagonismo e não nos motivos de cooperação», escreve-se na «Carta aberta». «Falta-

(M) Virtudes fundamentais da reforma da educação, p. 4.

(") Idem, p. 5.

(") Idem, p. 6.

(61) Seara Nova, s. n. ${ }^{\circ}, 27$ de Novembro, 1923, pp. 51-54. 
-nos o senso social, somos irredutíveis e absolutistas: ninguém se contenta, por isso, de poder impor parcialmente a sua opinião ou o seu critério; e, se se diverge num pormenor, não se procura colaborar: ataca-se a obra no seu conjunto, com arranques de nevropata e cegueiras de louco em fúria». $\mathrm{E}$, de modo mais explícito: «Não procederam desta forma os indivíduos que colaboraram com o Ministro sr. Camoesas: comportam» -se assim, todavia, a mor parte dos poucos críticos e adversários do projecto».

Em seguida, assinalando-se um acordo relativo com as suas principais disposições, considera-se o projecto meramente como uma base de trabalho: "Sente-se neste o concurso, ou convergência, de critérios diferentes mas complementares, e sem prejuízo, portanto, da sua unidade. O sensato, tanto nos defensores como nos críticos, seria reconhecer, antes de tudo, o que há excelente na tentativa, e apresentar depois com simpatia as correcções e aditamentos, pois como um esboço para ser emendado se apresentou, aliás, o projecto de lei» $\left({ }^{58}\right)$.

Aditando-se, em seguida, as «medidas susceptíveis de realização imediata», enunciava-se um conjunto de propostas muito semelhantes às que tinham ficado indicadas, poucos meses atrás, no "Apelo à Nação»: criação de quatro escolas experimentais - infantil, primária, secundária e de continuação-, com novo regime de composição de cursos; modificação de programas; criação do Museu Pedagógico de Lisboa, com a finalidade de organizar material de ensino para as escolas, publicar guias para os professores, etc.; remodelação do ensino normal e criação do Instituto de Ciências da Educação; criação de uma Junta de Promoção de Estudos; criação de uma Junta de Estudos Sociais; criação de uma Residência de Estudantes; fundação de um internato no tipo das Escolas Novas; contratação de professores estrangeiros, para, sobretudo, o ensino de continuação e o ensino técnico; nomeação de uma comissão executiva das reformas, e de uma comissão de reforma do ensino superior $\left.{ }^{59}\right)$.

Deste modo, é referenciável a preocupação crescente de Sérgio em isolar um conjunto de medidas a realizar por interposta pessoa ou directamente.

A evolução da conjuntura política não tardaria, entretanto, a proporcionar-lhe a sua única experiência de Governo.

( ${ }^{58}$ Idem, pp. 53-54.

(69) Idem, p. 54. 
$A$ equipe Álvaro de Castro - ele próprio dissidente do Partido Nacionalista, de Cunha Leal - pretendia ter feição extrarpartidária. Firmava-se, todavia, em três ministros com filiação no Partido Republicano Português, «mas com base de apoio neste partido, ainda hoje a mais sólida e bem organizada força do regime», escrevia $O$ Século, a 3 de Janeiro de 1924, bem como no conjunto de deputados e senadores que, saídos do Partido Nacionalista, como o próprio Álvaro de Castro, tinham constituído o Grupo Parlamentar de Acção Republicana. Integrava democratas de orientação radical como José Domingues dos Santos, Domingos Pereira e Mariano Martins, e dois representantes do Grupo da «Seara Nova»: Azevedo Gomes, na pasta da Agricultura, e António Sérgio na da Instrução Pública. O ministro da Guerra, major Ribeiro de Carvalho, embora não pertencesse à «Seara Nova», fora indicado pelo Grupo $\left({ }^{60}\right)$.

Constituído numa fase de aguda crise financeira, o governo de Álvaro de Castro enfrentava uma conjuntura política marcada pelo ascenso das forças da direita em direcção à ditadura militar. Reclamava-a o Partido Nacionalista, tendo à sua frente Cunha Leal, juntamente com todas as forças conservadoras que possuíam no Parlamento e nos quartéis as suas pontas de lança. Mussolini, na Itália, e Primo de Rivera, em Espanha, constituíam os modelos políticos que a direita pretendia implantar entre nós.

Álvaro de Castro assenta a sua prática governativa em três tipos de disposições: diminuição das despesas do Estado, aumento das receitas públicas, obtenção de divisas e controlo

(60)

O Século, na edição de 18-12-1923, afirma ter Álvaro de Castro principiado por convidar Cortesão a aceitar a pasta da Instrução Pública. Que o grande historiador foi convidado pelo Presidente do Ministério a entrar no Governo é facto declarado pela própria Seara Nova. Face à recusa de Cortesão, por ser conviç̧ão do Grupo «que os problemas nacionais se não resolviam parcelarmente, mas integrando-os numa obra de conjunto», Álvaro de Castro terá proposto a entrega de três pastas àquele núcleo de acção politica: Instrução, Agricultura e Guerra. Para as duas primeiras, como representantes do Grupo, a Seara indicou Sérgio e Azevedo Gomes, respectivamente. Para a terceira, o major Ribeiro de Carvalho, conquanto não pertencesse ao Grupo da «Seara Nova». («No Governo», in Seara Nova, (28), 1923, p. 71). De entre os representantes da Seara, Sérgio seria o ministro mais visado desde o início pelas ironias de duvidoso gosto de um deputado como Jorge Nunes, do Partido Nacionalista, ou de um Carvalho da Silva, monárquico de extrema direita. Assinale-se, a propósito, a atitude respeitosa e de admiração por Sérgio assumida por Lino Neto, deputado da minoria católica. 
do mercado de câmbios com vista a obstar à constante desvalorização do escudo $\left({ }^{61}\right)$.

A despeito dos aspectos impopulares deste programa quanto à redução das despesas com o funcionalismo, o Governo consegue obter, episodicamente, o apoio do movimento operário e das forças democráticas ante a conspiração fascizante visivelmente em curso. As jornadas de 15,16 e 17 de Fevereiro de 1924 assinalam os períodos culminantes do movimento unitário contra a ameaça de ditadura.

$\mathrm{O}$ movimento operário e democrático, entretanto, não está disposto a apoiar um governo que se revelava sem coragem para melhorar as condições de vida, sujeitas, dia-a-dia, a novos agravamentos. Uma manifestação calculada em perto de 150000 pessoas, e convocada pelas Juntas de Freguesia de Lisboa, reclama no Terreiro do Paço medidas eficazes «contra a carestia de vida», contra «os moageiros, comerciantes, banqueiros e todos os exploradores». Coroada por incidentais assaltos a padarias, a manifestação é pretexto para que o governo proiba um comício republicano-operário a 23 do mesmo mês na capital, apesar de a proibição não ser extensiva a outros pontos do território.

A falta de uma política de conteúdo popular, o governo Álvaro de Castro acabaria por perder definitivamente o apoio da única base social capaz de obstar ao avanço da direita fascizantę: o movimento operário e o movimento democrático.

E neste contexto social, político e financeiro que Sérgio inicia a sua primeira e única experiência governativa.

No acto de transmissão de poderes que decorre no Ministério da Instrução, Sérgio não enuncia quaisquer propósitos de rotura em relação a João Camoesas e a Melo e Simas, seus antecessores imediatos naquela pasta. Pelo contrário, frisa a continuidade de acção que pretende estabelecer e compromete-se a aplicar, na sua área, os princípios defendidos pelo Grupo «Seara Nova» $\left({ }^{62}\right)$.

Os dois primeiros actos de política da educação praticados por Sérgio têm a ver, por um lado, com a organização

(61) António José Telo, Decadência..., cit., pp. 268 e ss., em especial p. 273. Embora dissesse recusar a ditadura (que o eng. ${ }^{\circ}$ Cunha Leal declarava imprescindível à resolução dos problemas nacionais, assim como o anterior chefe do governo, Ginestal Machado), Alvaro de Castro (como a própria Seara) era manifestamente adepto da chamada «democracia musculada». A sua declaração política ao Parlamento não deixa a esse respeito quaisquer dúvidas. (Diário da Câmara dos Deputados, sessão n. $\left.{ }^{\circ} 15,21-12-1923\right)$. 1923, p. 71.

(62) O Século, 19-12-1923, e Seara Nova, (28), Dezembro, 
de um ramo de investigação científica na base de elementos pré-existentes e, por outro lado, na tentativa de criação, no aparelho do Estado, de um organismo orientador de toda a pesquisa educativa e científica, com carácter independente do poder político.

\section{Criação do Instituto do Cancro}

Com efeito, o decreto n. ${ }^{\circ}$ 9333, depois de historiar, no seu preâmbulo, as iniciativas levadas a efeito entre nós no sentido da investigação científica do cancro de 1901 a 1915, com Azevedo Neves, Soares Branco Gentil e Raposo de Magalhães, cria em Lisboa o Instituto Português para o estudo do Cancro, a funcionar provisoriamente no Hospital Escolar de Santa Marta.

O mesmo decreto reconhecia ao novo Instituto a autonomia técnica, científica e administrativa, «sem prejuízo do auxílio oficial que possa vir a ser-lhe prestado». Atribuia-lhe desde logo utilidade pública (dada a gravidade que a disseminação da doença tinha entre nós e a necessidade de a combater) e, como finalidades, organizar a luta contra o cancro em Portugal, manter e desenvolver um centro regional dessa luta em Lisboa, bem como promover e auxiliar a criação de outros centros regionais, praticar o estudo e a pesquisa científica da doença e divulgar os seus resultados, realizar campanhas de educação sanitária, melhorar as condições de trabalho dos seus investigadores e técnicos, fundar laboratórios de investigação científica, e adquirir equipamentos com vista à pesquisa e tratamento da doença.

O Instituto ficava igualmente autorizado a angariar e administrar os fundos que lhe fossem necessários e para os efeitos da sua direcção era nomeada uma comissão de cientistas, constituída pelos Drs. Francisco Gentil, Marck Athias, João Emílio Raposo de Magalhães, Henrique Fragoso, Domingos Parreira e pelo director do Serviço de Radiologia do Hospital Escolar, Francisco Bénard Guedes. A Comissão, cujas funções seriam gratuitamente desempenhadas, era presidida por Francisco Gentil, e os dois últimos elementos seriam os secretários $\left({ }^{63}\right)$.

(63) Diário do Governo, l.a série, n. ${ }^{\circ}$ 278,29-12-1932, pp. 1512-1513. 
De todas as iniciativas tomadas por Sérgio na qualidade de ministro da Instrução Pública foi esta, por certo, a que teve mais largo futuro e mais duradoura projecção. As nossas actuais instituições de combate e investigação do cancro tiveram aqui a sua raiz.

A Seara Nova, referindo com louvor a iniciativa, acrescenta, significativamente, ter ela sido tomada «sem a menor despesa para o Estado» (64).

«Velha aspiração» lhe chamaria Sérgio pouco depois $\left({ }^{65}\right)$, finalmente concretizada, o certo é que ela não figurava em nenhum dos pontos programáticos precisos que tivesse enunciado. Tudo indica que o ponto de partida foi uma realidade, apesar de tudo, já em marcha - a investigação e o tratamento científico do cancro-e não uma ideia apriorística, inscrita no universo estelar das «ideias».

\section{A Junta de Orientação dos Estudos e o boicote parlamentar}

No mesmo dia, a folha oficial inseria também o decreto n. ${ }^{\circ}$ 9332, que dava realidade jurídica dessa vez a uma das ambições mais gratas do novo ministro. Considerando tornar-se indispensável «criar um organismo técnico permanente que oriente e coordene não só todos os esforços de actualização do ensino português, como todos os trabalhos de investigação científica», escreve-se no respectivo preâmbulo, criava-se no Ministério da Instrução Pública «um organismo técnico permanente, que se denominará: Junta de Orientação dos Estudos......

A Junta de Orientação dos Estudos, segundo a opinião de Sérgio, teria funções assaz complexas. Seriam seus objectos organizar e fiscalizar um serviço de bolsas de estudo, promover a colocação dos ex-bolseiros segundo as habilitações obtidas, subsidiar investigações científicas, assim como a publicação dos respectivos resultados, fundar, manter ou auxiliar centros de estudo, fundar e dirigir escolas experimentais em todos os graus de ensino, exceptuando o superior, fundar e dirigir museus pedagógicos, e representar ao governo, de sua própria iniciativa, sobre assuntos de instrução.

(64) Seara Nova, (29), Janeiro, 1924, p. 91.

(65) Idem, (34), 9-4-1924, p. 195. 
É visível que, exceptuados os próprios estabelecimentos experimentais sob a sua alçada, a Junta não teria intervenção no sistema de ensino em funcionamento. O decreto facultava-lhe, porém, que considerasse "como centros de estudo seus aderentes») os estabelecimentos científicos, literários ou artísticos, assim oficiais como particulares, que quisessem colaborar nas suas actividades, «convencionando com esses estabelecimentos um regime de trabalho».

A Junta de Orientação dos Estudos seria sobretudo, pois, um instituto de investigação científica e pedagógica, com funções de organização e execução dentro da sua esfera de actividade.

Como pessoa colectiva, gozaria de autonomia administrativa e de capacidade jurídica para adquirir bens e os administrar, assim como à dotação que recebesse do Estado com vista à consecução das suas finalidades.

Sob o ponto de vista científico, a sua autonomia seria igualmente integral: cabe-lhe decidir, escreve-se no mesmo decreto, «sobre todos os casos das suas atribuições, fixará os programas e condições das bolsas de estudo e das escolas experimentais, fiscalizará o aproveitamento dos seus bolseiros e a sua colocação nos centros de estudo, concederá os subsídios ou auxílios necessários e contratará os funcionários e o pessoal docente de todas as instituições»».

Quanto à sua composição, a Junta de Orientação dos Estudos seria constituída de vinte e um vogais cujas funções eram desempenhadas gratuitamente. Os primeiros sete seriam de início nomeados pelo Governo. Os sete vogais seguintes seriam também de nomeação governamental mas sob proposta da Junta, bem como os restantes. Os vogais escolheriam de entre si a comissão executiva e o presidente, tendo ainda a Junta a faculdade de requisitar, em comissão de serviço, para as suas instituições, com autorização do Governo, os funcionários e professores oficiais de que carecesse. Caber-lhe-ia, também, propôr ao Governo os regulamentos indispensáveis ao seu funcionamento e seria ouvida obrigatoriamente quando tivesse de ser modificada a organização estabelecida pelo decreto.

A independência da Junta em relação ao poder político era, como se vê, quase completa. Pela nomeação dos vogais o Governo poderia, até certo ponto, controlar-lhe a composição inicial. Quanto ao seu funcionamento, a nova instituição ficava obrigada a publicar anualmente uma memória, dando conta dos seus trabalhos e dos seus actos administrativos, a ser presente ao ministro da Instrução. O seu orça- 
mento anual, bem como as condições a que a sua gestão obedeceria, deveriam ser submetidos ao Parlamento $\left({ }^{6 \mathrm{e}}\right)$.

O projecto de criação da Junta de Orientação dos Estudos suscitaria, naturalmente, reacções díspares.

Sérgio recorre à Imprensa afecta ao Governo para aclarar e precisar certos aspectos do seu pensamento. $\mathrm{O}$ traço que sublinha em primeiro lugar é o da independência da Junta relativamente ao poder político. Numa entrevista concedida ao jornal $O$ Século, a 29 de Dezembro, afirma que a instituição seria «um organismo autónomo», congregando "as nossas primeiras sumidades científicas e pedagógicas», que teria como seus aderentes os estabelecimentos oficiais ou particulares que livremente postulassem essa colaboração. Não se trataria de um órgão consultivo mas actuante, que actuaria «com plena independência, livre de peias burocráticas, de transigências políticas e que, declara, trabalhará paralelamente à organização oficial da instrução sem nela intervir, a não ser pelo exemplo e sem dela receber quaisquer indicações»».

Esta ideia de reestruturar o macro-sistema de ensino a partir de um micro-sistema que exercesse sobre o primeiro uma espécie de «contaminação» inovadora, é por certo um dos frutos mais directos do reformismo de Sérgio e constitui o traço definidor da sua política de educação.

A possibilidade de conflito institucional era evidente. Assim, enquanto a Seara Nova, nesse mesmo mês, aproxima a Junta de Orientação dos Estudos de um organismo análogo existente em Espanha, «renovador da ciência e da técnica espanhola», e lhe atribui o poder omnipotente de criar «sábios de verdade e técnicos para a agricultura, para o comércio, para a instrução, para toda a actividade nacional, - instrumentos de ligação e de preparação que estabeleçam o imediato

(66)Diário do Governo..., cit., pp. 1511-1512. Sérgio procurava realizar, como ministro, uma iniciativa, ao que parece gorada, da União Cívica, da qual dá notícia a Seara Nova, em Maio de 1923 , pela pena do próprio Sérgio: «Uma das reclamações mais importantes da União Cívica, escreve Sérgio, vai ser realizada por iniciativa particular. Têm-se efectuado, no Instituto Bacteriológico, as sessões preparatórias de uma Junta de Educação, instituto promotor do melhoramento da cultura nacional e da investigação científica. O seu principal objectivo será o de dar pensões de estudo no estrangeiro (de preferência aos que desejem consagrar-se às especialidades científicas de mais directa aplicação à utilidade nacional), criar institutos e auxiliar os que já existem, e fundar Residências de Estudantes. Cremos desnecessário encarecer a importância deste facto, e limitamo-nos a pedir para a Junta o amparo de todos os bons patriotas de todas as almas generosas da Nação» (p. 192). 
contacto com as forças produtivas» $\left({ }^{67}\right)$, Sérgio é muito mais cauteloso e modesto. A uma pergunta do entrevistador, que estabelecia uma aproximação entre a Junta de Orientação dos Estudos e a Junta de Ampliação dos Estudos de Espanha, o ministro seareiro apenas reconhece «muito ligeiros pontos de contacto» entre uma e outra. E apressa-se a acrescentar que a instituição agora criada «não vem, por exemplo, declarar guerra ao ensino universitário, como a espanhola».

O programa imediato de actividade da Junta portuguesa cifrar-se-ia, predominantemente, na organização da actividade científica e na promoção da investigação pedagógica experimental. Os propósitos enunciados desde a União Cívica e no próprio projecto de lei de João Camoesas vêm à tona uma vez mais.

Primeiramente, diz, a Junta «procederá a estudos de investigação científica, tanto no país corno no estrangeiro, especialmente encaminhados no sentido do fomento agrícola e industrial da metrópole e das colónias». Para tanto instituiria bolsas de estudo, dado que o sistema existente não era satisfatório, e manteria, no país, institutos de aplicação onde os bolseiros pudessem transformar os conhecimentos hauridos além-fronteiras para utilidade nacional.

Em matéria pedagógica, a Junta deveria fundar, manter e dirigir superiormente escolas-modelos de ensino infantil, primário, secundário e de continuação, bem como um museu pedagógico destinado à difusão de material didáctico, livros, etc.

Quanto aos recursos financeiros necessários, Sérgio revela a intenção de apresentar ao Parlamento uma proposta de lei destinada a criar receitas, ou antes, «transferindo fundos para ocorrer às necessidades da Junta» e que, além disso, contava com o auxílio de particulares. Revela igualmente a sua intenção de instalar a Junta em meados de Janeiro seguinte, presidindo ao acto o Presidente da República, Manuel Teixeira Gomes, que, diz Sérgio, «muito se tem interessado por esta ideia e que usará da palavra, significando-lhe o seu inteiro aplauso», aditando que ele próprio proferiria nessa altura uma conferência: "A finalidade nacional da reforma dos estudos; a reforma dos estudos e as duas políticas nacionais»".

Se o projecto de Sérgio é acolhido com simpatia nos meios científicos - a ajuizar, por exemplo, pelas declarações de Aurélio Quintanilha, feitas, nessa altura ao Diário de Lis-

(67) Seara Nova, (29), Janeiro, 1924, p. 91. 
boa, apesar do seu cepticismo em relação à benemerência particular -, nos meios políticos não tardaria a encontrar resistências.

No dia seguinte, 30 de Dezembro, O Século julgava poder revelar os nomes das sete primeiras individualidades cujo diploma de nomeação para a Junta deveria ter sido apresentado na véspera à assinatura presidencial e que Sérgio, na entrevista precedente, apenas dissera serem todos professores e terem «um carácter o menos oficial possível». A pergunta do entrevistador sobre se fariam parte da Junta os reitores das Universidades e directores dos estabelecimentos científicos e pedagógicos, Sérgio especificara que seriam recrutados «indistintamente».

Pelas informações de $O$ Século e da Seara Nova, a identidade dos indigitados justificava o ponto de vista do ministro da Instrução: eram Anibal de Bettencourt, Mark Athias, Gomes Teixeira, Luciano Pereira da Silva, Agostinho de Campos, José de Magalhães e Marques Leitão ( ${ }^{68}$ ).

Entretanto, porém, as nomeações não viriam a ser feitas. À reabertura do Parlamento após o período de férias, a oposição declarava-se disposta a atacar o projecto considerando-o inconstitucional. Desse modo, Sérgio prefere aguardar uma definição clara das forças políticas a esse respeito, como se lê na Seara Nova de 31 de Janeiro de 1924. "Os membros iniciais da Junta Orientadora de Estudos não foram ainda nomeados, nem apresentada ao Parlamento a proposta de lei que cria as receitas necessárias e regula o seu regime financeiro, escreve-se na secção 'No Governo', porque o Ministro entendeu mais conveniente só a fazer depois de realizado pela oposição o ataque, que anunciou, à constitucionalidade do decreto que instituiu a Junta» $\left({ }^{69}\right)$.

A situação arrastava-se e a 8 de Fevereiro noticiava $O$ Século que o Ministro da Instrução continuava a aguardar que o Parlamento se pronunciasse quanto à matéria.

A 16 de Fevereiro saem todavia na folha oficial duas propostas de lei relativas à administração da Junta e à obtenção dos recursos financeiros necessários ao seu funcionamento, as quais haviam sido enviadas ao Parlamento a 14 do mesmo mês.

Pela primeira proposta, confiava-se à Junta o seu próprio governo económico. Como pessoa colectiva eram-lhe atri-

(65) Idem, ibidem e O Século, 30-12-1924. Anunciava-se para esse dia uma conferência de Imprensa de Sérgio sobre o mesmo tema.

(69) Loc. cit., p. 113. 
buídas as prerrogativas inseridas no decreto instituidor e conferiam-se-lhe as seguintes receitas: bens, rendas, dotações ou subsídios que o Estado, ou quaisquer entidades, corporações administrativas ou particulares the concedessem; o produto da cobrança de quaisquer impostos especiais que por lei viessem a ser-lhe consignados como receita privativa; bens adquiridos ou procedentes de legados ou doações de particulares; o produto da venda de publicações e dos cursos remunerados ou instituições que organizasse.

Além de se regular o processo de aquisição de bens ou de aceitação de doações, estabelecia-se que a Junta decidiria sobre a aplicação dos seus rendimentos, "podendo contratar o pessoal docente e os funcionários de que carecer para o funcionamento dos serviços que instituir e arbitrar-lhe os respectivos vencimentos»».

Finalmente, declarava-se que as escolas fundadas ou auxiliadas pela Junta (caso em que ficariam sujeitas à sua fiscalização pedagógica e administrativa) seriam, para todos os efeitos, «equivalentes às escolas oficiais correspondentes» $\left({ }^{70}\right)$.

Esta proposta de lei continha, virtualmente, largos elementos de conflito. A passo que era completamente omissa quanto aos poderes da Junta para colocar bolseiros, fundar, organizar e dirigir instituições de investigação científica, conferia-lhe poderes de criação de um sistema de ensino paralelo, concorrencial com o existente, e extensivo não só a estabelecimentos oficiais como a particulares.

Poucos dias depois, a proposta é republicada no Diário do Governo por ter saído com inexactidões. O novo articulado, porém, apresenta uma só diferença. No $\S$ único do art. ${ }^{\circ} 5 .^{\circ}$, onde se dizia que a Junta poderia converter em moeda cor-' rente os fundos públicos a que se referia o artigo, sempre que tal fosse necessário para adquirir os «bens imobiliários» adequados aos seus fins, especificava-se que eles poderiam ser «rústicos ou urbanos» e acrescentava-se: «assim como expropriar por utilidade pública esses mesmos imóveis» ( $\left.{ }^{71}\right)$.

Este poder adicional desencadearia, certamente, sob o ponto de vista político, ainda mais dificuldades que os anteriores. Sérgio deverá ter recuado, porquanto, poucos dias depois, o Diário do Governo vem rectificar... a rectificação, no texto seguinte: «Para os devidos efeitos, e por ordem superior, se comunica que o texto da proposta de lei do Sr. Ministro da Instrução Pública, inserto no Diário do Governo,

(T0) Diário do Governo, 2.a série, n. ${ }^{\circ}$ 38, 16-2-1924, pp. 594-595.

(T1) Idem, ibidem, n. ${ }^{\circ}$ 5, 25-2-1924, pp. 707 e ss. 
n. ${ }^{\circ} 45$, de 25 do corrente, não está exacto, mas sim o publicado no Diário do Governo, n. ${ }^{\circ} 38$, de 16 do corrente» $\left({ }^{72}\right)$.

Sérgio previa, contudo, um processo menos «revolucionário» de obtenção dos recursos financeiros necessários ao funcionamento da Junta de Orientação dos Estudos. Uma proposta de lei inserida no mesmo número 38 do Diário do Governo criava um imposto de selo especial sobre as instalações eléctricas para iluminação de uso privado, a escriturar nas contas públicas sob a rubrica «Fundo Especial dos Estudos» e que se destinava a cobrir os encargos da Junta.

$\mathrm{O}$ imposto seria anual e recairia nas lâmpadas de energia eléctrica para iluminação, na base de $\$ 10$ sobre lâmpadas até 25 velas, $\$ 20$ para as de 25 a 50 velas, $\$ 30$ para as lâmpadas de 50 a 100 velas e de $\$ 60$ para as lâmpadas de poder iluminante superior a 100 velas $\left({ }^{73}\right)$.

É de admitir que tal imposto não tivesse uma produtividade financeira muito significativa, atendendo à relativa difusão da energia eléctrica. Recairia, contudo, sobre as classes sociais abastadas, as únicas que usufruiam deste conforto doméstico $\left({ }^{74}\right)$.

Poucos dias depois, Sérgio admitia ainda que a Junta de Orientação dos Estudos viesse a entrar em funcionamento. A Portaria $n$. $^{\circ} 3914$, reconhecendo a conveniência de promover a divulgação das publicações oficiais de carácter pedagógico, que o Ministério da Instrução iniciara com a edição do Boletim Pedagógico e de um folheto sobre a Junta, mandava que se confiasse a esta, e, enquanto não funcionasse, à Biblioteca Nacional de Lisboa, o serviço de distribuição e venda das citadas publicações, prestando as respectivas contas, nos termos legais, às instâncias superiores $\left({ }^{75}\right)$.

O projecto da Junta de Orientação dos Estudos não iria, contudo, avante. No acto de transmissão de poderes ao seu sucessor, coronel Helder Ribeiro, Sérgio afirma não ter nomeado os seus membros por não terem sido ainda aprovadas nas Câmaras as propostas relativas ao governo económico dela e à percepção das receitas necessárias ao seu funcionamento. "Logo declarei ser-me indiferente a maneira de obter essas receitas, diria nessa ocasião; importa ao pedagogista que elas existam, não a sua proveniência: e creio que o me-

(") Idem, ibidem, n. ${ }^{\circ} 48,28-2-1924$, p. 750.

(73) Idem, ibidem, n. ${ }^{\circ} 38$, cit., p. 594.

("5 Cf. David de Carvalho, Os Sindicatos Operários e a República Burguesa. 1910-1926, Lisboa, Seara Nova, 1977, p. 21.

(75) Diário do Governo, $1 .^{\mathrm{a}}$ série, n. ${ }^{\circ} 43,25-2-1924$, p. 318. 
lhor serviço que poderiam prestar as oposições seria apontarem-nos as fontes que lhes parecem de recomendar» $\left({ }^{76}\right)$.

É manifesto não ter Sérgio compreendido — nem, segundo parece, o Grupo «Seara Nova» - que as razões profundas do boicote parlamentar à Junta de Orientação dos Estudos eram múltiplas e tinham a ver com o cerne da política educativa ministerial.

\section{O conflito do ensino primário superior}

Ao mesmo tempo que tentava reestruturar o sistema de ensino unicamente por intermédio da activação de pressões endógenas e se afadigava em obter os fundos necessários ao lançamento de um micro-sistema paralelo, cujos efeitos se poderiam manifestar apenas no longo prazo, Sérgio tomava disposições altamente controversas em relação ao sistema de ensino em funcionamento.

Com efeito, um dos mais graves incidentes da sua carreira no governo tem a ver com as escolas primárias superiores e com a concepção do ensino de continuação.

Apesar da indiscutível função social que desempenhavam em benefício das classes médias e populares, sobretudo quanto ao sexo feminino, as escolas primárias superiores vinham sendo objecto de críticas contundentes.

A tentação de as suprimir já se manifestara, aliás, no governo de Ginestal Machado, sendo Melo e Simas ministro da Instrução Pública. Contra essa intenção se desenvolvera nos meios republicanos uma vigorosa campanha $\left({ }^{77}\right)$.

Em começo de 1924, e no âmbito da política de «redução de despesas públicas», uma das directrizes fundamentais do Governo de Álvaro de Castro, as escolas primárias superiores são suprimidas. A 3 de Janeiro, $O$ Século noticia em primeira página: "A compressão de despesas. São extintos o Supremo Tribunal Administrativo, as auditorias administrativas e as escolas primárias superiores. As divisões militares são reduzidas a quatro».

No vasto conjunto de disposições adoptadas, e que estão longe de se circunscrever às enunciadas no título de $O$

(76) «No Governo» in Seara Nova, (34), 9-4-1924, p. 195.

(n) Ver, por exemplo, O Rebate: 28-11-1923, 29-11-1923, 30-11-1923, 6-12-923, 9-12-1923, 12-12-1923; 13-12-1923. Serra Frazão e Lino da Silva são, neste jornal, os grandes artífices dessa campanha de defesa das escolas ameaçadas. 
Século, figurava na verdade a supressão das escolas primárias superiores estatais.

Essa determinação veio pouco depois a ser objecto do decreto . $^{\circ}$ 9354, emanado do Ministério da Instrução Pública.

O respectivo preâmbulo começava por considerar como «organismo da maior importância no sistema de educação pública de uma sociedade moderna e democrática». o «tipo de instituição educativa denominado Escola Primária Superior, ou de Continuação».

Considerava em seguida, e por isso mesmo, cumprir que os vários estabelecimentos desse tipo fossem organizados de harmonia com «a definida finalidade que lhes corresponde»- e que o decreto não dizia qual fosse- $-\mathrm{e}$, acrescentava-se, «com o maior escrúpulo pedagógico, quer na sua estrutura legal, quer na composição do seu pessoal docente».

Aduzia depois o decreto, nos seus considerandos, que as escolas primárias superiores portuguesas não haviam sido organizadas «segundo aquela bem definida finalidade social que compete a esse tipo de escolas, nem com o necessário rigor na admissão do pessoal docente, nem segundo os melhores princípios pedagógicos»».

Afirmava-se, ainda, a conveniência de «seleccionar esse pessoal, submetendo a concurso de provas públicas aqueles dos seus membros que foram admitidos sem demonstração suficiente do seu saber nos ramos de ciência que ensinam e nas didácticas respectivas»; a necessidade «de estabelecer uma nova estrutura pedagógica das nossas escolas primárias superiores, de acordo com a função social que compete a esse género de escolas e com as mais recentes experiências pedagógicas neste ramo de ensino»; e, por último, evocava-se o decreto com força de lei de 29 de Março de 1911, segundo o qual competiam aos municípios as despesas inerentes ao referido grau de ensino.

Com base nestas considerações, Sérgio deita por terra em cinco breves artigos todo o edífício do ensino primário superior. A partir de 30 de Março daquele ano, seriam suprimidas todas as Escolas Primárias Superiores criadas pelo Estado. Poderiam todavia subsistir aquelas cujas despesas, na sua totalidade, fossem directamente providas pelos Municípios ou pelas Juntas Gerais dos Distritos, sob a condição de o respectivo pessoal reunir «as condições de idoneidade necessárias para o exercício da sua função, verificadas nos termos que oportunamente forem fixados»».

Todo o pessoal docente, administrativo e menor das escolas suprimidas passaria à situação de adido, nos termos do decreto n. ${ }^{\circ} 8469$, de 6 de Novembro de 1922. Contudo, os 
docentes que acumulassem outras funções do magistério ou de qualquer outro serviço público não receberiam vencimento como adidos em razão da supressão das mesmas escolas.

Por fim, o decreto comprometia o Governo a apresentar oportunamente ao Parlamento «as medidas necessárias para a remodelação do ensino primário superior nos moldes do ensino de continuação que melhores provas tem dado na experiência pedagógica, e para seleccionação do respectivo pessoal docente» $\left({ }^{78}\right)$.

De golpe, Sérgio eliminava 51 estabelecimentos de ensino, albergando 2311 alunos (1338 dos quais eram do sexo feminino) e 638 professores, na sua quase totalidade efectivos. E se é certo que a eventual passagem ao quadro de adidos significaria 5/6 do vencimento para o pessoal (a menos que exercessem a docência em acumulação), para os alunos a extinção das escolas, para mais a partir de 30 de Março, isto é, antes do final do ano lectivo, significava a inutilização de todo um curso.

Um relatório do Governo, publicado a 9 de Janeiro, justificando as actividades até então desenvolvidas, afirma sobranceiramente: «Quando a opinião esclarecida verifica que um instituto de ensino é inútil, o Estado tem o dever ou de o remodelar profundamente ou de o suprimir. Por agora o Governo entendeu optar por este caminho. A extinção das escolas primárias superiores do país, há tanto tempo reclamada com razão, é, pois, um facto».

Essa «opinião esclarecida» era, sobretudo, a de alguns elementos do Grupo «Seara Nova» já que, no projecto João Camoesas, as escolas primárias superiores seriam globalmente convertidas em escolas técnicas elementares. Bem podia, pois, a Seara Nova regozijar-se com a supressão das «escandalosas escolas primárias superiores», que não podiam defender a sua existência, afirmava-se na revista, «tais como funcionaram, senão apontando outros graves abusos, outros escândalos, a necessidade de supressão de outros males nacionais» $\left({ }^{79}\right)$.

Não era a opinião de milhares de alunos, professores, encarregados de educação, órgãos do poder local, deputados e senadores.

A campanha contra a extinção das escolas primárias superiores vai ser conduzida, na Imprensa e fora dela, pelos professores - que dispunham, desde 1922, de uma Associação do Professorado das Escolas Primárias Superiores e de outras or-

(78) Diário do Governo, l.a série, n. ${ }^{\circ}$ 4, 7-1-1924, pp. 18-19.

(79) Seara Nova, 29, Janeiro, 1924, p. 91. 
ganizações de carácter sindical - , pelos encarregados de educação, pela oposição parlamentar e, entre outros jornais, pelo diário A Batalha, que não nutria pelo Grupo «Seara Nova» e, em especial por Sérgio, nenhuma simpatia política $\left({ }^{80}\right)$.

O professorado diligenciou, desde logo, ser recebido pelo Ministro da Instrução Pública num encontro que esteve longe de decorrer de forma pacífica.

Com efeito, a 9 de Janeiro, no Parlamento, o deputado Hermano de Medeiros dirige-se a Sérgio para fazer considerações sobre factos de "carácter grave». $\mathrm{Na}$ véspera, dia 8, na imediata sequência da publicação do decreto, afirma o deputado terem ido os professores das escolas primárias superiores, «em manifestação ordeira», procurar o ministro, «para pedirem justiça - é o termo». Constava, acrescenta, que Sérgio se recusara a recebê-los, a pretexto de ter um dia reservado a tais audiências. "Esses professores pretendiam defender junto de Sua Excelência a sua causa, observa o deputado, mas chegou a ser dada ordem para um esquadrão da guarda republicana ir destroçar esses professores, entre os quais há nomes que se devem respeitar».

O ministro desdramatiza o incidente. Os professores tinham-se dirigido ao Ministério no próprio dia da publicação do decreto no Diário do Governo. Recebidos por um secretário ${ }^{81}$ ), ter-se-ia «esboçado um pequeno conflito» que o ministro mandara averiguar por outro secretário.

Sérgio acabara por se avistar com os docentes na manhã do dia 8 e quanto à eventualidade de intervenção da

$\left.{ }^{80}\right)$ Veja-se o artigo «O Grupo 'Seara Nova' - Três pastas e um ministro que põem fim a uma ilusão e a um programa», in $A B a-$ talha, 29-12-1923, p. 1. A referência a António Sérgio é especialmente mordaz (e com laivos de injusta) mas fundada em razoes políticas: «O sr. António Sérgio, tão conservador, que preconizou no famoso manifesto da União Cívica - uma das metamorfoses da 'Seara Nova' - o combate das ideias sindicalistas, anarquistas e comunistas, limita-se apenas a ter uma ambição como outra qualquer pessoa banal... E a 'Seara Nova'? a 'União Cívica'? e os 'Homens Livres'? Três ambições com pastas de ministro no Terreiro do Paço».

Refira-se, todavia, que, logo a 12 de Janeiro, o jornal O Rebate insere um artigo de Serra Frazão de ataque a Sérgio.

$\left.{ }^{81}\right)$ Data de 26 de Dezembro de 1923 a portaria de nomeação do assistente da Faculdade de Medicina, Dr. Luís Robertes Simões Raposo para chefe de gabinete de Sérgio, com a gratificação mensal de $83 \$ 33$ (Diário do Governo, 2. a série, n. 299 , p. 4478). Augusto Reis Machado, professor efectivo do $4 .^{\circ}$ grupo do Liceu de Mousinho da Silveira (Portalegre) é nomeado secretário do ministro apenas em 22 de Janeiro de 1924 (Diário do Governo, 2. ${ }^{\mathrm{a}}$ série, n. ${ }^{\circ} 18$, p. 9.269). 
Guarda Republicana, limita-se a declarar textualmente: «eu não a requisitei» $\left({ }^{82}\right)$.

Hermano Medeiros, que diz saber ter tido o Ministro do Interior (Sá Cardoso) «passada a ordem para sair um esquadrão da guarda republicana para o referido fim», não se dá por satisfeito e declara desejar interpelar Sérgio sobre a supressão das escolas $\left({ }^{83}\right)$.

Em números sucessivos, A Batalha levará por diante a luta extra-parlamentar com incansável energia.

O Governo, por intermédio de uma nota distribuída à Imprensa insinuara a existência de um núcleo de docentes que tentava semear a insânia entre a classe. Essa manobra desmobilizadora não surte efeito. Em meados de Janeiro reúnem-se na Escola Adolfo Coelho, na capital, os professores das Escolas Primárias Superiores com larga representação, diz o jornal, de todo o país.

Embora a situação material dos professores das extintas escolas primárias superiores não fosse considerada lesiva, os docentes repudiam a imposição de se submeterem a concursos de provas públicas, que, em Portugal, diz A Batalha, eram sempre «uma fíç̧ão».

A assembleia de professores aprova uma moção em que se pede ao Parlamento a suspensão imediata do decreto e ao Governo «um estudo ponderado do assunto para a eficaz remodelação das Escolas, como se impõe».

Com vista ao prosseguimento da luta é nomeada uma comissão constituída por Alberto Magno, Mendes da Costa, Amaro de Oliveira, Artur Neves, Monteiro de Andrade, Virgílio Pedrosa, Lino da Silva, Aníbal Passos e Eduardo Marcelo $\left({ }^{84}\right)$.

A fim de melhor poderem conduzir a campanha contra a extinção das escolas primárias superiores, os respectivos docentes organizam comissões regionais: uma na zona norte e outra das escolas aquém-Mondego. Como era de prever, não tardarão a receber testemunhos de solidariedade por parte de outros sectores da classe docente. $\mathrm{Na}$ reunião havida na Escola Adolfo Coelho, os professores das antigas Escolas Normais, que haviam sido incorporadas nas escolas primárias superiores, declaram pretender apresentar-se também a concurso, ao lado dos colegas.

c $\left.^{82}\right)$ Diário da Câmara de Deputados, sessão n. ${ }^{\circ}$ 17, 9-1-1924, p. 9. (") Idem, ibidem, p. 25.

í) A Batalha, 15-1-1924, p. 2. 


\section{António Sérgio}

A Associação dos Professores de Portugal, aderente à Internacional dos Educadores, distribui por seu turno uma nota oficiosa em que Sérgio, os critérios do governo e o próprio Grupo da «Seara Nova» são violentamente contestados. A Associação dos Professores de Portugal constata a urgente necessidade de «remodelar profundamente todo o nosso sistema educativo, no sentido de o integrar nas necessidades da coleetividade, formando o homem integral e profissional que há-de edificar o novo mundo que o determinismo social lhe impõe...... Observa ainda que «a extensão e intensificação da cultura das massas populares é a pedra angular de todo o progresso social», pelo que protesta contra a extinção das escolas primárias superiores. Considera esse acto, em primeiro lugar, como um atentado "contra uma alta conquista das classes populares e contra os legítimos direitos de cultura»; em segundo lugar, "por constituir uma violenta e odiosa medida de excepção ante a defíciente produção de todo o corpo da educação nacional, em face das imperiosas necessidades da hora presente». Regista, depois, «o estranho facto» de que o governo e o Grupo «Seara Nova» preferissem comprimir as despesas públicas do Ministério da Educação às do Ministério da Guerra, e conclui: «A Associação dos Professores de Portugal, vivendo acima de estreitos interesses de corporativismo, norteada pelos mais altos ideais pedagógicos e humanos, afirma mais a doutrina de que os governos, por mais patriotas que sejam os seus homens, não têm o direito de ser parciais nem de remir com a miséria e a humilhação dos funcionários públicos os crimes acumulados do Estado» $\left({ }^{85}\right)$.

Sobre estas tomadas de posição acrescentavam-se pressões de origem diversa na Câmara de Deputados. A 8 de Janeiro, é recebido um ofício do director da Escola Primária Superior de Mangualde enviando uma moção de protesto contra a supressão das escolas. Vinte dias depois, é a Comissão do Professorado do Ensino Primário Superior da zona norte que reclama. Protestavam também, por telegrama, o Centro Democrático e Associativo dos Artistas e Operários de Gouveia, e as Câmaras Municipais de Fafe, Famalicão, Arcos de Valdevez

(85) Idem, 22-1-1924, p. 1. O funcionalismo público era duramente atingido pelas medidas de Álvaro de Castro. Sobre o desenvolvimento do movimento sindical na função pública, ver: Nogueira de Brito, Em marcha. Notas e comentários sobre a greve do funcionalismo público em 1920, Lisboa, Seara Nova, 1976; Beatriz Ruivo e Eugênio Leitão, O Sindicalismo do Funcionalismo Público na I República, Lisboa, Seara Nova, 1977. 
e Santarém, bem como o Partido Republicano Nacionalista de Mirandela ( ${ }^{86}$ ).

Se as associações de professores e outras organizações sociais se manifestavam contrárias à supressão das escolas primárias superiores, os pais e encarregados de educação não se mostravam menos activos.

No mesmo dia em que a assembleia de professores se reunira na Escola Adolfo Coelho, congregava-se uma assembleia de pais na sede da Universidade Livre. Os interesses dos alunos não tinham sido devidamente acautelados pelo decreto, tanto mais que as escolas seriam extintas a 30 de Março, isto é, antes do final do ano lectivo. Assim, além de um telegrama de protesto e da nomeação de uma comissão de luta, formula-se até a proposta, nã̃o retida nas resoluções finais, valha a verdade, de se facultar aos alunos o direito de se matricularem em qualquer curso de escolas superiores com o aproveitamento obtido nas cadeiras que terminassem $\left({ }^{87}\right)$.

A reunião de pais cifrava-se num vigoroso ataque à política do governo e da burguesia. Assim, depois de se focar a existência de cerca de $70 \%$ de analfabetos na população portuguesa, afirmava-se que se abriam liceus e se alargavam Universidades, ao mesmo tempo que se votava «ao mais profundo desprezo a assistência escolar e o incremento do ensino primário e profissional». Havia, assim, um excedente de diplomados, a par com «a falta absoluta da cultura profissional nas oficinas, no comércio e na agricultura».

Os pais reclamavam, a um tempo, contra a supressão de comarcas (também decretada pelo Governo) e contra o encerramento das escolas primárias superiores. Propunham que se saneassem os parasitas, se assegurasse a independência dos homens públicos nas empresas capitalistas, se aproveitassem melhor os funcionários. Propunham ainda o encerramento das escolas de preparação militar e que se aplicassem os oficiais em serviços úteis. «O que se dispensa, acrescentavam, são decretos que mandam fechar escolas, que afastam a frequência e causam o descrédito dos professores. $\mathrm{O}$ que se precisa é que o senhor ministro visite as escolas e veja do que elas carecem e o que fazem».

C) Diário da Câmara dos Deputados: Sessão n. 16, 8-1-1924, pp. 3-4; idem, Sessão n. ${ }^{\circ} 20,15-1-1924$, p. 3; idem, sessão n. ${ }^{\circ} 25$, 22-1-1924 , p. 4; idem, sessão n. ${ }^{\circ} 29$, 28-1-1924, p. 3; idem, sessão n. ${ }^{\circ} 31$, 6-2-1924, p. 4; idem, sessão n. ${ }^{\circ} 41,21-2-1924$, p. 3 ; idem, sessão n. ${ }^{\circ} 43$, 15-2-1924, p. 3.

(87) Vd. O Século, 14-1-1924 e A Batalha, 15-1-1924. 
Nesta perspectiva, a assembleia reivindica a revogação do decreto, «que nem sequer acautela os direitos dos alunos matriculados», que «o ensino se organize de modo a atender à cultura geral, prática e técnica, de preferência à preparação universitária» e, finalmente "se faça incidir sobre os exploradores do povo - a finança - uma contribuição que se destine à assistência e ao desenvolvimento intenso da instrução primária e profissional» $\left({ }^{88}\right)$.

Pouco depois, os pais dos alunos avistam-se com o Ministro da Instrução «e fizeram-lhe ver, escreve $A$ Batalha, que alunos haviam, e muitos, que ficam com os seus cursos incompletos, e que, hoje, manter uma criança numa escola custava muitos sacrifícios e muito dinheiro. A supressão dessas escolas, aditava-se, vinha tornar vãos todos esses sacrifícios, todo esse esforço considerável» $\left.{ }^{89}\right)$.

Esta situação era bem real. Poucos dias depois, inseria o mesmo jornal uma carta da estudante Alzira Santos, saudando A Batalha e protestando veementemente contra a medida de António Sérgio. A sua identificação social era clara e por certo bem representativa de milhares de colegas: «Sou forçada a interromper os meus estudos, escrevia a jovem, porque sou pobre, escasseando por isso os meios de frequentar o liceu» $\left({ }^{90}\right)$.

A campanha contra a supressão das escolas primárias superiores continuará a desenvolver-se de acordo com três linhas de força principais: desacordo com a extinção; acentuação do papel social das escolas, essencialmente procuradas pelas classes populares e camadas médias; proposta de reforma das mesmas escolas no sentido da sua ligação à vida e ao trabalho.

Assim, A Batalha, criticando a decisão «iníqua» de Sérgio, rejeita a justificação de que a supressão das escolas seria o único remédio a aplicar à sua falta de utilidade social e, principalmente, a ausência de solução alternativa ( ${ }^{91}$ ). «Não negamos, escrevera pouco antes o mesmo jornal, que as Escolas Primárias Superiores tinham um programa educativo deficiente. Mas mesmo assim deficientes as Escolas Primárias Superiores eram mais úteis abertas que fechadas». E acrescentava: «A pretexto de economias fechar escolas que alguma coisa de útil produziam é um contrasenso. Não realizaria

(") A Batalha, 24-1-1924, p. 1.

(") Idem, 19-1-1924, p. 1 .

O Idem, 22-1-1924, p. 1.

(") Idem, 22-1-1924, p. 1. 
o Estado muito maiores economias encerrando por exemplo a Escola de Guerra e a Escola Naval? Essas sim, são absolutamente inúteis, porque oficiais que vivem à custa do povo para o mandar acutilar já existem muitos» $\left({ }^{92}\right)$.

$\mathrm{Na}$ verdade, enquanto o orçamento do Ministério da Guerra, para 1924-1925, inscrevia um total de 225.030.514\$32, o da Instrução Pública somava apenas 95.759.975\$30 (93).

Não surpreende, pois, que $A$ Batalha não poupasse a política orçamental do Governo, considerando-a um reflexo dos interesses do grande capital. Em editorial, e sob o título «A compressão de despesas. Poupa-se o orçamento da Guerra e sacrifica-se o orçamento da Instrução», A Batalha acusava o ministério Álvaro de Castro de obedecer às chamadas «forças vivas», que bem podiam declarar «o Estado somos nós». Evocando os denominados «congressos económicos», que dizia serem «assembleias magnas compostas por industriais e comerciantes, por toda a espécie de capitalistas», invariavelmente «assistidas por ministros», afirmava que nelas se «trovejara» e «grunhira» em todos os tons o slogan: «a redução das despesas do Estado». E acrescentava: "Está feita, ou antes quase concluída a expressão da vontade das forças vivas. Entrou-se nas medidas reclamadas pelos que vivem de explorar toda a população do país»».

A Batalha continuava com energia: «O pensamento das forças vivas sobre a vida é tudo quanto há de mais simples, ganhar a maior porção de dinheiro ao povo e dar o menos possível ao Estado. Ó pensamento do actual governo afina pelo diapasão das chamadas forças vivas: arrancar o máximo dinheiro aos contribuintes e retribuir-lhes o menos possível». Pondo em contraste a diferença entre as verbas orçamentadas para os Ministérios da Instrução e da Guerra, A Batalha concluía: "As forças vivas pensam orgulhosamente, patrioticamente, que um povo quanto mais ignorante mais obediente. As tiranias assentam na obediência. A melhor obediência é a que não raciocina. E a ignorância é incapaz de uma boa reflexão». «O país, assim como está, prosseguia causticamente o editorialista, é que convém. A ignorância é um filão inextinguível. As forças vivas não agrada, pois, a instrução. E em obediência a esse desagrado, o ministério da instrução é um dos mais atingidos pela chamada compressão de despesas»».

A questão das escolas primárias superiores é evocada pelo articulista neste contexto. «Para tapar a boca aos pre-

( $\left.{ }^{\circ}\right)$ Idem, 19-1-1924, p. 1.

C93) O Século, 16-1-1924. 
juízos causados e aos protestos dos prejudicados e dos que sensatamente discordam de semelhante medida, fala-se em arranjar modo de as substituir. Sobre esse modo de substituir, o actual ministro da Instrução não precisa a sua ideia. Limita-se a anunciá-la, muito no vago, muito no ar... Concretamente: deitam-se abaixo de uma assentada, as Escolas Primárias Superiores. Abstractamente: promete-se encontrar maneira de evitar os prejuízos que essa destruição acarreta» $\left({ }^{94}\right)$.

A acção de Sérgio não deixaria de ser combatida no jornal ao longo de todo o mês de Janeiro. Sob o título contundente e jocoso de «As Escolas Primárias Superiores. - Comentários azedos à obra do actual ministro da Instrução, luminar da 'Seara Nova', alta montanha da pedagogia que afinal deu à luz um rato. - Serena autópsia ao ratinho recém-nascido», novo editorial era consagrado, poucos dias depois, ao ministro «seareiro» da Instrução.

O editorialista começava por afirmar as elevadas responsabilidades contraídas pela «Seara Nova» em razão das suas críticas aos processos de governação republicana. Evoca ironicamente as expectativas existentes em relação a Sérgio, não, é certo, sem laivos de injustiça. No essencial, porém, a crítica é pertinente. Incidia, sobretudo, no facto de Sérgio, visando reestruturar o sistema de ensino, não atacar os seus problemas fundamentais. «Depois de s. ex. ${ }^{a}$ dar à luz a Junta Orientadora dos Estudos, escreve A Batalha, os bons dos nossos crentes esperavam que o seu homem, fugindo aos contactos mortíferos da grande porca, subisse às altas regiões da Orientação, congregando as energias positivas de todo o ensino, irradiando luz potente, amorosa e criadora sobre esta triste charneca que é o analfabetismo intelectualista de Portugal»».

Assim, prosseguia A Batalha, esperava-se que Sérgio, «vendo o organismo social crivado, sugado e desnorteado por espessas nuvens de parasitas diplomados, transformasse os liceus, como medida de salvação pública, em escolas de continuação, de educação integral, ou de qualquer outra coisa útil que não tivesse portas para a mesa do orçamento. Houve até quem asseverasse que a envergadura moral do sr. António Sérgio não permitiria que ao orçamento da instrução se cortasse um só centavo, enquanto não fossem enviados aos nossos milhões de analfabetos os 3000 professores que aí an-

O A Batalha, 20-1-1924. 
dam miseravelmente por gazetas e ministérios a pedir pão e trabalho».

A dualidade dos critérios reformadores do ministro, resultantes da sua opção pessoal pelo ensino de continuação, tornava-se, deste modo, de uma dolorosa evidência. Em todas as suas anteriores tomadas de posição pública sobre questões de educação, o autor dos Ensaios criticara acerbamente o carácter verbalista e livresco do ensino liceal. Considerava, porém, de maior urgência o estabelecimento do ensino de continuação, por ser essa a via que faria decrescer a frequência dos liceus e das Universidades, alfobres de inúteis diplomados.

Sem a menor dúvida, a supressão das escolas primárias superiores provocava um estranho contraste com a imunidade a que pareciam votados outros ramos socialmente «nobres». Começara-se a «reforma» com a extinção de uma via de ensino popular, produzindo-se, por tal modo, o efeito contrário ao pretendido.

«Em frente do panorama do ensino, dos seus defeitos, continuava o editorial de $A$ Batalha no seu ataque a Sérgio, arma em banalíssimo político: abre os olhos para uns, fechar -os para outros, deixa-se infiltrar de ódios e, num gesto de vai ou racha, assim à Cunha Leal, extingue as escolas primárias superiores, como quem decreta por atacado a moralização pedagógica e financeira da República». E concluía: «O sr. António Sérgio faria mil vezes mais em favor da instrução do povo e do pobre doente que é a instrução nacional, vasando as escolas primárias superiores nos moldes precisos e orientando generosamente o seu pessoal em vez de o desprestigiar» (95).

Essa dualidade reflectia-se, ainda, noutro facto. Ao mesmo tempo que anunciava a extinção do ensino primário superior, $O$ Século fazia saber, a 6 de Janeiro, a intenção do Ministério da Instrução Pública de consultar o presidente da Associação do Magistério Liceal sobre as economias a realizar no ensino secundário. "Que admirável igualdade de tratamento!», comenta, e com razão sobeja, A Batalha no mesmo artigo.

A argumentação de $A$ Batalha e de outros intervenientes no debate vai salientar que a extinção das escolas primárias superiores visava, mais do que a realização de economias, a «moralização» do seu corpo docente, obrigando-o a provar a sua competência profissional.

De facto, como sublinha o jornal, no artigo citado, a maioria dos docentes ficaria na situação de adido com ven-

(95) Idem, 16-1-1924. 
cimento. O próprio pessoal menor seria transferido para os liceus, que deste modo viam reforçados os seus meios de acção $\left.{ }^{96}\right)$. Subsistia, portanto, como questão de fundo, a da competência dos professores, em que A Batalha via a real determinante da extinção das citadas escolas.

A crítica a uma política de compadrio quanto ao preenchimento dos quadros do ensino primário superior vinha de longe. A Batalha não a rejeitava por completo mas atribuía ao Estado a responsabilidade dessa política. «Se o ministério da Instrução tem sido uma alcova da política, não são as Escolas Primárias Superiores que merecem ser suprimidas, escreve-se noutro editorial. Suprimam, mas é ao Ministério da Instrução, a alcova das cartas de empenho, das transigências vergonhosas e fáceis.... Expurgue-se as Escolas Primárias Superiores das incompetências que as infiltram» $\left({ }^{97}\right)$.

A necessidade de reforma das escolas primárias superiores e de correcção das anomalias imputáveis aos favoritismos nas nomeações do respectivo pessoal era reconhecida pelos próprios defensores desse ramo de ensino. Carvalhão Duarte, protestando contra o gesto de Sérgio, que, em seu entender, ia contra a essência do regime republicano e demonstrava «um soberano desprezo pelos direitos do povo e pouca atenção pela Instrução Popular», marcava todavia o seu desacordo com a política prevalecente no preenchimento dos lugares nessas escolas. Aquando da criação daquele grau de ensino, escreve, «discordámos da maneira como foi seleccionado o seu pessoal». E que, prosseguia, «os governos de então, salvo muitas excepções, fizeram prevalecer sobre a preferência da competência a preferência do compadrio». Esse falso critério, porém, não vigorava apenas em relação às escolas primárias superiores...

Carvalhão Duarte aceita, ainda, se diga haver excesso de professores e de pessoal menor nessas escolas. Nem por isso concorda com a extinção, nem com a exigência de provas de competência aos professores nomeados. Recusando o princípio de realizar economias (ainda por cima fictícias dado que os adidos venciam $5 / 6$ do ordenado) à custa dos filhos dos trabalhadores, e apontando a GNR e o Exército como alvos preferenciais delas, pugnava por um ensino mais prático, sobretudo técnico, regionalizado, conjuntamente com o ensino científico e literário do curso geral, devendo permitir

(") Decretos n.os 9423 e 9468, in Diário do Governo, 1.a série, n. ${ }^{\circ} 32$ e 49 , respectivamente, pp. 269 e 344.

O A Batalha, 27-1-1924, p. 1. 
o ingresso nos estudos superiores mediante um sistema de bolsas que captasse os estudantes pobres «que quisessem seguir a carreira das letras», e preconizando a difusão de tais escolas à escala das sedes de concelho $\left({ }^{98}\right)$.

Poder-se-ia, contudo, operar a reconversão das escolas primárias superiores, no sentido por que lutava Carvalhão Duarte (e, bem vistas as coisas, não muito distante, sob esse aspecto, da concepção de Sérgio), sem proceder a uma reconversão dos seus professores?

Numa conferência sobre «Educação Popular», proferida na mesma ocasião, recordava Aníbal Passos que a questão da «incompetência» dos professores fora sempre a base de combate às escolas móveis oficiais e às escolas primárias superiores, as duas grandes realizações republicanas de democratização da instrução. O orador demonstrava a falsidade da acusação, salientando que, na sua maior parte, os professores das escolas primárias superiores tinham leccionado nas antigas escolas normais e que os restantes eram, sobretudo, médicos e advogados (").

Poder-se-ia, com esses professores, conferir o carácter técnico e prático que Sérgio pretendia imprimir ao ensino de continuação?

Neste ponto as dificuldades seriam, certamente, consideráveis. No seu afã de procurar uma alternativa para a supressão de 51 escolas, Sérgio revelar-se-ia, contudo, totalmente incapaz de criar, sob esse aspecto, as condições favoráveis à reforma e de satisfazer as justas reclamações do professorado, das famílias e dos estudantes.

$\mathrm{O}$ decreto $\mathrm{n} .{ }^{\circ}$ 9354, que extinguira as escolas primárias superiores, é republicado a 9 de Fevereiro, «por ter saído com inexactidões».

As duas emendas principais situam-se, em primeiro lugar, num dos respectivos considerandos. Onde se escrevera que tais escolas não tinham sido organizadas segundo uma «bem definida finalidade social», nem «segundo os melhores princípios pedagógicos», nem «com o necessário rigor na admissão do pessoal docente», esta última frase era suprimida. Tratava-se de uma satisfação formal ao professorado agre-

(98) A Batalha, 5-2-1924, p. 1 e 15-2-1924, p. 2. Note-se que a defesa da tecnicização do ensino pós-elementar, com ou sem despenalização relativamente aos estudos superiores, é assaz comum na época nos meios operários e revolucionários. Veja-se, por exemplo, César Oliveira, O Primeiro Congresso do Partido Comunista Português, Lisboa, Seara Nova, 1975, pp. 62-63.

(") A Batalha, 8-2-1924, p. 1. 
dido, mas deveras incompleta visto manter-se a exigência da prestação de provas.

Em segundo e último lugar, a supressão das escolas era protelada para 30 de Junho, ou seja, para o termo do ano lectivo, o que, salvaguardando melhor os interesses dos alunos, estava longe de resolver o problema de fundo que era a ausência de equivalências e portanto a impossibilidade de prosseguir estudos $\left(1^{\circ}\right)$.

As declarações de Sérgio sobre o que viria a ser o ensino primário superior ou de continuação eram, com efeito, demasiado vagas e nada tranquilizantes. Não abriam quaisquer perspectivas positivas aos dois milhares de alunos que no fim do ano lectivo ficariam sem escola.

"As escolas primárias superiores, escrevia a Seara Nova, em finais de Janeiro, ecoando, certamente, as ideias oficiais, serão substituídas por um ensino que prepare os indivíduos para o exercício das profissões médias, fundando desde já a Junta [de Orientação dos Estudos] uma escola modelo com pessoal estrangeiro habilitado» $\left({ }^{101}\right)$.

Este projecto de uma escola-modelo, como contrapartida para meia centena de escolas eliminadas, e, ainda por cima, orientada por professores estrangeiros, era com efeito de molde a provocar um irado cepticismo.

Sérgio persistiria nessa orientação, embora a luta desenvolvida por A Batalha acabasse por produzir efeitos.

Assim, na tempestuosa sessão comemorativa do aniversário de Monsanto, levada a efeito em Lisboa no Centro Tomaz Cabreira e a que adiante nos referiremos, Sérgio diria tencionar apresentar, entre outros, um projecto de lei que lhe permitisse «desenvolver e aperfeiçoar o ensino primário superior, tirando-lhe o carácter doutoral, e dando-lhe um carácter de treino prático para as necessidades da vida do trabalho e da cultura cívica democrática, - de maneira que, a par de uma cultura geral suficiente, prepare para os cargos médios das profissões, como sejam chefes de oficina, empregados de escritório, caixeiros viajantes, regentes agrícolas, etc.» $\left({ }^{102}\right)$.

Nem por isso desistia, contudo, do projecto de uma escola experimental de continuação com as características que sempre defendera.

Deslocando-se à capital do Norte na comitiva de Teixeira Gomes, terá uma reunião com delegados da Câmara

(10) Diário do Governo, n. ${ }^{\circ}$ 30, l.a série, 9-2-1924, p. 255.

(101) Seara Nova, (29), Janeiro, 1924, p. 91.

(102) Idem, (30), 31-1-1924, p. 114. 
Municipal, das Associações Comercial e Industrial, do Instituto Superior de Comércio e da Faculdade Técnica. A reunião, de que os professores nortenhos do ensino primário superior eram excluídos, destinava-se a obter apoio para a criação de uma escola primária desse tipo mas «sem os programas fantásticos das actuais e com secções dirigidas por técnicos estrangeiros, possivelmente alemães, como alemão poderia ser o material didáctico e até o pavilhão onde funcionasse»». Quanto aos meios de efectivação deste projecto, tanto mais vago quanto era certo não dever ser a língua alemã acessível aos presumíveis discípulos de tais professores, declara Sérgio ter-se lembrado da Alemanha por termos em nosso poder valores alemães, tais como as prestações em dívida das indemnizações de guerra, bens dos alemães nos Açores e em Moçambique e algumas cargas dos vapores daquela nacionalidade.

Em resposta, o representante do Município do Porto limitou-se a dizer tencionar reunir-se com as Juntas de Freguesia, como «legítimas representantes do povo». Nada de mais concludente, segundo o noticiário, parece ter saído da reunião, a não ser a oferta de Sérgio para a realização de conferências de propaganda $\left({ }^{103}\right)$.

O ministro recebe, no dia seguinte, a Comissão de Defesa das Escolas Primárias Superiores da Zona Norte e a sua linguagem destina-se, visivelmente, a apaziguar-lhe os ânimos. Assegura que, não convidando para a reunião da véspera os docentes das escolas suprimidas, não quisera desconsiderar nem o professorado nem a Comissão. Quisera, apenas, «conseguir opinião» para a entrega das preciosidades assírias (parte dos bens alemães) em troca de material didáctico. Desculpa frágil, como são as restantes declarações proferidas, segundo o relato de O Século: «Em resposta ao sr. dr. Álvaro Corte Real, que disse ao sr. António Sérgio da mágoa que lavra no pessoal docente das Escolas Primárias Superiores, pela injustiça havida para com ele, nos considerandos que antecedem o decreto 9354, afirmou o sr. ministro, diz o jornal, não ter o propósito de ferir a prestimosa classe dos professores primários superiores, nem tão pouco o de extinguir este grau de ensino. Pensa apenas em o reorganizar....»

Comunicara igualmente o ministro, informa o mesmo jornal, «que uma maneira interessante e verdadeiramente moral de fazer economias no seu Ministério seria restituir às escolas do ensino primário a sua primordial função, actualmente exercida pelos liceus, que, para o ensino da instrução secun-

(103) O Século, 8-2-1924. 
dária, ocupam uma enorme quantidade de professores, agregados e provisórios, o que constitui para o orçamento do Estado um encargo bem mais pesado que o da sustentação das Escolas Primárias Superiores» (104).

Estas palavras conciliatórias, onde é visível o impacto da campanha desenvolvida por $A$ Batalha, não tranquilizavam o professorado. Aprazada nova reunião para Lisboa, a Comissão não deixaria de indicar ao ministro «várias modificações a fazer em relação ao pessoal superior do seu ministério, as quais trariam sensível economia sem prejuízo do serviço»» (105).

Por outro lado, a Comissão tem o cuidado de se munir de uma proposta alternativa. Assim, avista-se com o reitor Augusto Nobre para lhe apresentar as modificações introduzidas pela classe no projecto de lei por ele apresentado quando ministro. Mostrando-se concordante com essas propostas, Augusto Nobre promete agir em defesa das escolas primárias superiores» $(106)$.

As palavras de Sérgio dariam base, por outro lado, a três artigos inseridos em $A$ Batalha e assinados D.M.C.

No primeiro, salienta o autor a função social das escolas primárias superiores em relação aos filhos dos proletários, apesar da «brutalidade» dos programas. Quanto à sua função primordial, que actualmente, segundo Sérgio, seria exercida pelos liceus, D.M.C. comenta com ironia que ela se reduz à realização do exame do $2 .^{\circ}$ grau.

O segundo artigo é mais extenso e mais incisivo. Abre com uma crítica desvastadora ao ensino Iiceal português e ao sistema de bolsas de estudo existentes para os estudantes pobres, só facultadas aos alunos que ficassem distintos nos exarmes. «Os governantes da República, na sua maioria, diz D.M.C., têm sido cruéis com a instrução popular». Não teriam feito mais, aliás, do que desorganizá-la por completo, reservando todas as atenções para com a instrução dos ricos e «descuidando por completo a educação e instrução da classe proletária».

No terceiro artigo, D.M.C., que diz ser um «velho professor», apresenta sugestões concretas em relação ao futuro das Escolas Primárias Superiores.

«Por mais de uma vez, escreve, se tem afirmado que uma das funções mais importantes das Escolas Primárias

$(104)$ Idem, 10-2-1924.
$(105)$ Idem, 11-2-1924.
$(106)$ Idem, 15-2-1924. 
Superiores seria o que tivesse por fim a transição gradual e suave entre a instrução primária e a secundária e ninguém melhor que os professores primários com aptidões para 0 desempenho dessa melindrosa missão se poderia encarregar dela».

Nas condições do sistema de ensino existente, D.M.C. apresenta uma proposta engenhosa e exequível. O ensino dos primeiros três anos dos cursos liceais passaria a ser ministrado nas Escolas Primárias Superiores, «com grande vantagem para a instrução e educação; e com extraordinária economia para os cofres do Estado»».

Os alunos pobres, ou os que se matriculassem com a expressa declaração de desejarem obter o curso como habilitação necessária para as artes ou ofícios ou para a entrada nas escolas técnicas, não pagariam matrícula, ao contrário dos restantes. «Modificando-se os programas de forma que os alunos possam aproveitar tanto quanto possível, e dando-se pelo menos 15 tempos de serviço semanal a cada um dos professores, estava resolvido o problema das Escolas Primárias Superiores, conclui, e os menos favorecidos da fortuna terão, como os ricos, institutos acessíveis à instrução e educação dos seus filhos» $\left({ }^{107}\right)$.

Sérgio inflectiria a sua política educativa em relação às escolas primárias superiores à medida que a campanha de protesto se desenrolava.

É certo não ter abandonado o projecto de criação de uma escola experimental de "continuação» regida por mestres de além-fronteiras e que tal projecto parece, finalmente, concretizável. A Seara Nova, em Fevereiro, inclui, entre outras iniciativas do Ministério da Instrução Pública, o entendimento com a Câmara Municipal do Porto, com as Associações Comercial e Industrial da mesma cidade e com os directores do ensino técnico superior, «com recursos financeiros, especificava a revista, que essas entidades se esforçarão por conseguir» para o fim de fundar uma Escola de Continuação «com pessoal estrangeiro para os trabalhos manuais e secções técnicas» $(108)$.

Aponta igualmente a Seara Nova a nomeação de uma Comissão Pedagógica que, entre outros encargos, receberia o de estudar o programa das futuras «escolas de continuação». Constituída pelos professores José António de Magalhães, Augusto Pires Celestino da Costa, Adolfo Bernardino

(10T) A Batalha, 13-2-1924, p, 2; 16-2-1924, p. 1; 20-2-1924, p. 1. (108) Seara Nova, (31), 15-2-1924, p. 132. 
Sena Marques e Cunha, Carlos Adolfo Marques Leitão, João da Silva Correia Júnior e Manuel de Jesus Subtil, tal Comissão destinava-se a «estudar algumas reformas urgentes, que pelo Ministro lhe serão indicadas, a introduzir na organização do ensino, e quanto possível de acordo com as bases do projecto de reforma de educação apresentada pelo ex-Ministro Dr. João Camoesas, tendo a dita comissão a faculdade de agregar quem queira, para estudos especiais e de pormenor» $(109)$.

Ao abandonar as suas funções ministeriais, Sérgio reafirmaria ao seu sucessor a intenção, no âmbito do intercâmbio com a Alemanha, de «determinar a vinda de professores deste país, pela conta das reparações ou das cargas dos navios ex-alemães, inclusivé para as aulas de carácter técnico de uma escola de continuação modelo, que pretendia criar no Porto» $(110)$.

Quanto às Escolas Primárias Superiores, apenas se lhes refere num pós-escrito do relatório apresentado a Helder Ribeiro, com quem afirma já ter tratado verbalmente do assunto. «Era minha ideia, (com que S. Ex. ${ }^{\text {a }}$ concordou), diz Sérgio, que os trabalhos de gabinete e de inspecção para a reforma do Ensino Primário Superior estivessem ultimados antes de Julho, de maneira que durante as férias se preparasse tudo para a abertura das escolas reformadas no princípio do próximo ano lectivo. S. Ex. ${ }^{\mathrm{a}}$, finaliza o ex-Ministro, concordou comigo, e nesse sentido se está trabalhando actualmente» (U1).

Esta declaração era a segunda e última que Sérgio enunciava quanto à intenção de restaurar as escolas primárias superiores reformadas e não apenas de fundar uma escola-modelo desse tipo.

Tal inflexão era, obviamente, o resultado da campanha conduzida por A Batalha, pelo professorado e pelos pais, embora o decreto de supressão não tivesse sido revogado pelo governo nem pelas Câmaras (112).

$\left({ }^{109}\right)$ Diário do Governo, 2. ${ }^{\text {a }}$ série, n. ${ }^{\circ}$ 36, 14-2-1924, p. 863.

(110) Idem, p. 197.

(m) Idem, p. 197.

$\left.C^{12}\right)$ Sérgio terá um diálogo cordato com Silva Barreto, no Senado, acerca das escolas primárias superiores e diz ter nomeado uma comissão de pessoas competentes para a reforma dos diferentes serviços do mesmo grau de instrução primária. (O Século, 20-2-1924). 


\section{Projectos de reforma do ensino liceal}

A polémica sobre a extinção das escolas primárias $s u$ periores fora acompanhada, como vimos, de frequentes alusões à estranha imunidade do ensino liceal face à energia reformadora de que Sérgio dera provas.

Essas referências eram, por vezes, assaz precisas. Um leitor, J. C. Alves, dirige-se ao jornal $O$ Século para evocar os princípios da reforma de João Camoesas e salientar a nomeação de 750 professores interinos para os liceus devido ao excesso de alunos, com os quais se gastaria a verba de 5200 contos. Afirma, depois, que a redução do curso liceal para cinco anos e o provável aumento do número de horas de serviço docente obrigatório, libertaria o Governo, de futuro, da necessidade de nomear um só professor provisório, realizando uma economia que permitiria custear as despesas do ensino técnico nas escolas primárias superiores $\left({ }^{113}\right)$.

O Governo fizera saber, com efeito, o propósito de realizar reformas e economias no ensino liceal, para o que se propunha, como vimos, consultar o presidente da Associação do respectivo professorado $\left({ }^{114}\right)$.

O Século noticiava igualmente, em Janeiro, que o Ministro da Instrução pensava aumentar para 18 horas semanais obrigatórias o serviço docente nos liceus. O Ministro informava, dizia ainda o jornal, que o Conselho de Ministros apenas aprovara, «em princípio, a necessidade do aumento do serviço obrigatório, o qual seria variável segundo o número de anos de serviço dos professores do ensino liceal», tornando-se tal determinação extensiva, «por equidade», ao corpo docente dos demais ramos de ensino (115).

A rapidez de reacção do professorado liceal é fulminante. Uma Comissão de professores dos liceus Alexandre Herculano, Rodrigues de Freitas e Feminino, do Porto, e do Liceu de Grão-Vasco, de Viseu, pede audiência ao ministro devido ao projectado aumento de horas de serviço, que qualifica de exagerado (116).

Esta determinação, que Sérgio apresentará mais tarde como consumada mas de que não achamos rasto jurídico $\left({ }^{117}\right)$, era acompanhada da intenção de adoptar medidas de carác-

(113) O Século, 12-2-1924.

(114) Cf. Gomes Bento, História do Movimento Associativo dos professores do ensino secundário. 1891-1932, Porto, 1973.

(n5) O Século, 23-1-1924.

(116) Idem, 25-1-1924.

C"') Seara Nova, (30), 31-1-1924, p. 113. 
ter restritivo em relação ao ensino liceal. Assim, $O$ Século noticiara, ainda em Janeiro, que, pela pasta da Instrução, se deliberara passar de centrais a nacionais alguns liceus do país e extinguir aqueles cujo movimento escolar não justificasse a existência (11S).

Além disso, Sérgio insistirá no cumprimento da lei orçamental n. ${ }^{\circ} 403$ quanto às justificações de faltas dos professores dos liceus. Em primeiro lugar por intermédio de uma circular de 7 de Fevereiro e, depois pela Portaria n. ${ }^{\circ}$ 3910, esclarecendo-se que estas disposições legais eram igualmente aplicáveis aos professores, em tudo o que não contradissesse as disposições regulamentares do decreto $n .^{\circ} 7558$ ou estivesse em desarmonia «com a natureza especial das suas funções docentes» $\left({ }^{119}\right)$.

Quanto à reforma do ensino liceal, não disporá de tempo para a concretizar embora tenha tido lugar na sua acção. Já em Janeiro referira $O$ Século ser intento do Ministro «aperfeiçoar os programas das diversas disciplinas dos liceus, reduzindo-os ao que é indispensável e coordenar entre si os da mesma classe» $\left({ }^{12}\right)$.

A preocupação de racionalizar a estrutura curricular dos liceus sob o ponto de vista vertical, libertando-a de matérias inúteis, e de lhe assegurar uma correcta articulação horizontal interdisciplinar é visível como directriz no projecto de reforma em esboço. Assim parece confirmar a referência de Sérgio aos trabalhos da Comissão Pedagógica por ele nomeada, a qual, apesar das poucas sessões realizadas, pudera determinar, segundo afirma, «o esquema da organização do ensino primário e secundário, os seus vínculos com o universitário e o especial» e escolher os professores encarregados de delinear os novos programas, os quais, aditava, «deverão ser muito podados em relação aos actuais, e coordenados entre si, de maneira tal que constituam, enfim, a unidade da classe, o que entre nós nunca se deu» $\left({ }^{121}\right)$.

(,ls) O Século, 5-1-1924. Sérgio extinguirá também 34 lugares de guardas em diversos liceus (Decreto n. 9413 , Diário do Governo, 1. (B) Série, (28), 7-2-1924).

(11в) O Século, 2-2-1924 e Diário do Governo, l.a $^{\mathrm{a}}$ série, n. ${ }^{\circ}$ 38, 19-2-1924, p. 299.

(120) O Século, 21-1-1924.

$C^{21)}$ Seara Nova, (34), 9-4-1924, p. 195. De notar que a expressão «ensino especial» significava, na época, ensino profissional ou profissionalizante. 
Acção de Sérgio no ensino superior e a demissão do reitor da Universidade de Coimbra

Em relação aos demais problemas do sistema de ensino registam-se intervenções pontuais de Sérgio, marcadas às vezes, pela emergência de dissonâncias ou até de rasgados conflitos.

$\mathrm{E}$ o caso do ensino superior e, designadamente, da Universidade de Coimbra.

A preocupação de «racionalização» dos serviços e de eliminação dos «excedentes» de pessoal levou Sérgio, na mesma data em que extinguia as escolas primárias superiores, a suprimir também as secretarias privativas das Faculdades e Escolas daquela Universidade.

$\mathrm{O}$ facto de funcionarem nos mesmos edifícios ou em edifícios muito próximos, e de a única razão da sua existência ser uma paridade apenas aparente com as demais Universidades, as ditas secretarias são extintas, passando todo o expediente a fazer-se, como antes da sua criação, pela Secretaria-Geral.

O pessoal administrativo e menor que não acumulasse o exercício de funções com outras quaisquer funções públicas remuneradas passaria à situação de adido, não percebendo vencimento, nessa qualidade, aquele que acumulasse outras funções públicas $\left({ }^{122}\right)$.

Se a determinação não suscita, em si mesma, reacções negativas, já o mesmo não sucede com a nomeação do chefe da extinta secretaria da Faculdade de Medicina da Universidade para o lugar de oficial-maior da Secretaria-Geral.

Tal nomeação, que recaía numa influente figura política local, e, segundo se diz na Imprensa do tempo, amigo pessoal de Álvaro de Castro, vinha preterir as expectativas de promoção do $1 .^{\circ}$ oficial da mesma Secretaria-Geral, promoção que, a ocorrer, teria arrastado a subsequente promoção dos restantes funcionários.

Este mecanismo do preenchimento de uma vaga, aliás existente desde 11 de Maio de 1922, firmava-se em legislação de 1911 e de 1918 mas a proposta do seu provimento, apresentada pelo Reitor António Luís Gomes a 13 de Maio de 1923, não obtivera sanção ministerial, visto que a lei n. ${ }^{\circ} 971$, de 17 de Maio de 1920, suspendia as promoções até à remodelação dos serviços públicos. 7-1-1924, p. 18.

(122) Decreto n. ${ }^{\circ}$ 9353, in Diário do Governo, $1 .^{a}$ série, n. ${ }^{\circ}$, 
A nomeação feita por Sérgio, além de retirar um só funcionário da situação de adido, significava, de facto, uma promoção, visto que, saltando por sobre funcionários mais antigos, passava de um ordenado de $1080 \mid 00$ para o de $1440 \$ 00$ mensais.

Aos protestos do trabalhador preterido junta-se o de todos os amanuenses e o do Reitor António Luís Gomes, que, recusando-se a aplicar o decreto de nomeação, se demite.

Colhido de surpresa, o ministro tenta sem êxito demover António Luís Gomes, que, porém, não só abandona o cargo como se retira para a sua casa do Porto.

O Senado, por seu turno, toma posição em apoio do reitor demissionário, salientando, sobretudo, o contraste entre a rapidez de resolução de um caso pessoal e a considerável demora na solução de outros problemas, bem mais graves, da Universidade, tais como o da concessão de uma verba de 50 contos em dívida por parte do Estado, e o do provimento «de lugares técnicos que há muito se arrasta perante as instâncias superiores e cujo adiamento tem causado os mais graves embaraços»».

Opina o Senado, também, que o cargo de oficial-maior da Secretaria-Geral não só não devia ser provido como devia ser extinto, o que leva o funcionário nomeado a pedir o seu regresso à anterior situação de adido e Sérgio a publicar o decreto n. ${ }^{\circ} 9458$ que extingue o cargo de oficial-maior da Secretaria-Geral da Universidade de Coimbra (123).

Sérgio nomeará reitor interino o Prof. Manuel Fernandes Costa, da Faculdade de Farmácia, e tentará substituir António Luís Gomes.

O primeiro indigitado será Bernardino Machado, a quem o ministro visita na sua casa da Cruz Quebrada mas que declina o convite em nome do princípio da autonomia univer- ${ }^{*} 47$

(123) Sobre esta questão refiram-se, apenas, os documentos essenciais: Decreto n. ${ }^{\circ}$ 9353, Diário do Governo, l. $^{\mathrm{a}}$ série, n. ${ }^{\circ}$ 4, 7-1-

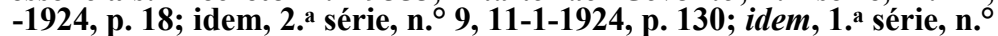

47, 29-2-1924, pp. 333-334; A Batalha, 5-2-924; O Século, 5-2-1924; entrevista de António Luís Gomes, Diário de Lisboa, 6-2-1924 e, ainda, no mesmo jornal, noticiário de 9-2-1924. Acerca do mesmo assunto, consulte-se também «Epistolário da Biblioteca Municipal de Coimbra. 534. De António Sérgio a Manuel da Silva Gayo», Arquivo Coimbrão. Boletim da Biblioteca Municipal, dir. de Armando Carneiro da Silva, (25), Coimbra, 1970, n. ${ }^{\circ}$ s52 e 553, pp. 360-361, e Seara Nova, (31), 15-2-1924, pp. 132-133. A versão dada pela revista corresponde certamente à de Sérgio e tem pelo menos o mérito de corroborar a sua boa fé política. 
sitária e da eligibilidade dos reitores, referindo $O$ Século o eventual convite subsequente a António José de Almeida (124).

A demissão do Reitor António Luís Gomes, porém, só em Março, quando Sérgio se não achava já no Ministério, virá a ser publicada na folha oficial, sendo a data respectiva a de 27 de Fevereiro, véspera da própria exoneração do ministro $\left({ }^{125}\right)$.

A questão da autonomia universitária e do princípio da eligibilidade dos Reitores não deixou de preocupar Sérgio. Assim, uma das tarefas cometidas à Comissão Pedagógica teria sido o estudo do primeiro daqueles problemas. No respeitante ao segundo, declara ao seu sucessor ter sido sua intenção «voltar à completa autonomia das Universidades, que elegeriam os seus reitores, com um delegado do Governo junto delas»» (126).

Para Sérgio - contrariamente ao ponto de vista de Bernardino Machado - o regresso ao regime de eligibilidade dos reitores universitários não implicava uma autonomia completa, na medida em que previa o princípio da interferência governamental, particularmente perigosa, aliás, sob o ponto de vista político, naquela conjuntura.

Como quer que fosse, o certo é ter tido Sérgio, por duas vezes, ocasião de pôr em prática o princípio da eligibilidade dos órgãos de gestão universitária e se ter abstido de o fazer. Deve-se-lhe, com efeito, não só a nomeação do reitor interino da Universidade de Coimbra, embora nesse caso se admita o carácter urgente desse acto, mas também a do vice-reitor da Universidade do Porto, Dr. António Joaquim de Sousa Júnior, professor ordinário da Faculdade de Medicina respectiva $\left({ }^{127}\right)$.

Para além de despachos de nomeação de pessoal docente $\left({ }^{128}\right)$, Sérgio não deixaria de dar alguma atenção à Universidade oficial.

(124) O Século, 24-1-1924; idem, 31-1-1924; Diário de Lisboa, 30-1-1924.

(125) Diário do Governo, 2. a série, n. ${ }^{\circ} 55,9-3-1924$, p. 821.

(126) Seara Nova, (34), 9-4-1924, p. 116.

(127) Diário do Governo, 2. a série, n. ${ }^{\circ 1}$, 20-2-1924, p. 643.

(128) Para a substituição de Alves dos Santos, entretanto falecido, nas cadeiras de pedagogia e psicologia infantil e do curso de moral e instrução cívica superior da Escola Normal Superior de Coimbra, Sérgio nomeará, precedendo proposta do director respectivo, os profs. José Joaquim de Oliveira Guimarães, Joaquim de Carvalho e Maximino Correia (Diário do Governo, 2.a série, 5-3-1924, p. 789).

Será igualmente por despacho de Sérgio que Paulo Mereia, professor ordinario da Faculdade de Direito de Coimbra, veria possibilitada a sua colocação em lugar idêntico na Faculdade de Direito da 
Em relação à Universidade do Porto, receberá, em Janeiro, uma comissão encabeçada por Leonardo Coimbra, que se desloca a Lisboa para protestar contra o anúncio de supressão de várias Faculdades universitárias. A verdade é que tal anúncio fora feito pelo ministro Ginestal Machado, mas atendendo à continuidade de orientação que, sob esse aspecto, se verificava, a Universidade do Porto considerava mais acertado antecipar-se. Sérgio tranquilizou a comissão, assegurando não existir, por então, tal projecto $\left({ }^{129}\right)$.

Mais tarde, por ocasião da sua deslocação ao norte, visitará diversos estabelecimentos de ensino e terá uma reunião de trabalho na Reitoria. Entre os assuntos ventilados terão figurado algumas questões particularmente árduas, sendo formulados alvitres sobre a actualização das propinas, a autonomia universitária, a inspecção do ensino e a criação de cursos livres mas também focados problemas relativos ao regime de classes no ensino liceal, à redução dos programas e à comparticipação de professores universitários nos júris dos exames liceais $\left({ }^{130}\right)$.

Quanto à Faculdade de Medicina do Porto, Sérgio terá diligenciado obter-lhe melhores instalações, transferindo-a para um edifício ocupado pela Guarda Nacional Republicana, e estabelecendo, para esse efeito, negociações com o Ministro do Interior (131).

As suas iniciativas específicas em relação ao ensino superior lisboeta, além da criação do Instituto do Cancro, circunscreveram-se à demorada conferência com os conselhos escolares dos Institutos Superior Técnico e Superior de Comércio com vista à remodelação de programas de ensino (132).

capital a partir do fim do ano lectivo de 1923-1924. (Diário do Governo, 2. ${ }^{\mathrm{a}}$ série, n. ${ }^{\circ}$, 9-1-1924, p. 96).

Sérgio, aliás, referira-se, em carta a Manuel da Silva Gayo, (acertadamente situada por Armando Carneiro da Silva entre Novembro-Dezembro de 1923) a Paulo Mereia e ao seu desejo de se deslocar para Lisboa: «Falou-me em tempos em se arranjar para o Merêa uma situação em Lisboa. Escrevi a este há pouco consultando-o sobre a possibilidade de ele aceitar uma comissão de estudos de reformas agrárias e políticas; mas ele, contra a minha espectativa, escusou-se» (in Arquivo Coimbrão..., cit., pp. 359-360).

(129) O Século, 12-1-1924.

(130) Idem, 8-2-1924.

(131) Seara Nova, (34), 9-4-1924, p. 196. Em relação à Faculdade de Medicina de Coimbra, limitar-se-á a transformar a cadeira de Psiquiatria num curso e a realizar operação inversa quanto à Propedêutica Médica. (Decreto n. ${ }^{\circ}$ 946, Diário do Governo, $10^{\mathrm{a}}$ série, 3-3-1924, p. 343).

(132) O Século, 21 e 28-1-1924. 
As Universidades debatem-se, nesta fase, com graves dificuldades orçamentais, para as quais o Senado de Coimbra, como já advertimos, reclama providências. Por outro lado, na Câmara de Deputados, o ex-ministro João Camoesas também chamou a atenção de Sérgio para o facto de a falta de pagamento aos empregados dos institutos científicos, que, observa, careciam de meios de funcionamento. "Encontram-se alguns na situação de não terem sequer os recursos necessários, como o Instituto de Anatomia Patológica, para autópsias, nem pessoal para a limpeza do laboratório, particulariza o antecessor de Sérgio. Os próprios médicos, que ali trabalham gratuitamente, fazem a sustentação da limpeza». Camoesas apresentava, em seguida, uma alternativa concreta dentro da verba orçamental existente, na convicção de que não poderia ser negado o voto a uma proposta nesse sentido.

Em resposta, o ministro dará o seu assentimento a esses pontos de vista e diria já ser seu propósito fazer que os institutos fossem dotados com os necessários meios. Tal proposta não viria, contudo, a ser apresentada à Câmara de Deputados (133).

A política universitária de Sérgio não se distingue por qualquer traço expansionista. Era seu convencimento, pelo contrário, de que o carácter socialmente elitista do ensino geral criava uma população discente universitária destituída de reais aptidões para esse grau de ensino.

Assim, nesse período, terá ocasião de declarar que um dos aspectos da democratização do ensino seria «dificultar o acesso das altas carreiras universitárias aos filhos dos ricos que não têm capacidade para os mais difíceis trabalhos de ciência e da literatura; e, pelo contrário, facilitar esse acesso aos filhos dos pobres que nasceram com talentos» (134).

A pretexto de democratização do ensino superior e face à crise financeira, Sérgio considerou dispositivos correctivos que, no plano imediato, poderiam acarretar a diminuição da sua frequência e que, portanto, se apresentavam entre si contraditórios.

Com efeito, deve-se-lhe a declaração pública de pretender aumentar o preço das propinas das Universidades, «de maneira a dificultar o seu acesso aos pouco aptos para a alta cultura, obtendo dinheiro, ao mesmo tempo, para as bolsas 
de estudo aos filhos dos pobres que tenham talento para as altas funções intelectuais» (135).

Tornar mais cara a frequência do ensino superior sem a contrapartida nítida da sua gratuitidade aos filhos das classes populares e sem outros princípios de discriminação positiva a favor dos mesmos, seria tomá-lo ainda mais elitista sob o ponto de vista social. Se os «menos aptos» eram os «mais ricos», esses poderiam suportar sempre o aumento de propinas, ao passo que os «outros» veriam esse grau de ensino ainda mais distante. Por outro lado, o ensino de continuação, tal como o concebia, aparecia apontado a objectivos profíssionalizantes assaz restritos, e, pela força desse facto, havia de constituir um bloqueio aos estudos subsequentes.

Como quer que seja e surpreendentemente, tais objectivos sociais não tardam a desaparecer do horizonte. As bolsas de estudo para estudantes pobres acabam por não ser contempladas neste plano. «Está pendente um projecto de aumento de propinas, dirá no acto de posse de Helder Ribeiro, que permitiria libertar a verba de 250 contos inscrita no orçamento para material escolar dos vários liceus, e metade destinada às Universidades. Estas somas tencionava eu propor que se repartissem por serviços que carecem de recursos; entre as aplicações mais necessárias, especificaria, figura uma anuidade para pagamento de juros e amortização de um empréstimo destinado a melhorar as instalações dos liceus do Porto, um reforço à dotação da Faculdade Técnica desta cidade, e subsídios a publicações científicas e a universidades populares» $\left({ }^{136}\right)$.

Quanto às Universidades populares existentes ao tempo - a Universidade Popular Portuguesa e a Universidade Livre para Educação Popular, de Lisboa - o certo é que não tiveram grande peso nas suas preocupações imediatas. A primeira terá passado, até, por um período crítico por falta de um pequeno subsídio estatal que lhe era concedido, crise de que $A$ Batalha se fez eco em vigorosa notícia: "A Universidade Popular vai desaparecer por culpa do Estado» (137).

(135) Idem, ibidem.

(136) Idem (34), cit., p. 196.

(13T) A Batalha, 12-1-1924, p. 2. 
Acção social escolar e condições materiais de ensino

Em relação ao ensino primário geral, Sérgio terá procurado atender à crítica situação em que se achavam as escolas mas a sua preocupação fundamental seria prepará-las para novas tarefas educativas. Desse modo, referia a Imprensa em Janeiro, o Ministro da Instrução começaria em breve as suas visitas às escolas da capital, «a fim de verificar o estado em que muitas delas se encontram e as urgentes modificações que convirá introduzir-lhes, por forma a tirar-se resultado do que se prescreve na Reforma do Ensino e antes mesmo de ser aprovada a parte propriamente pedagógica» $\left({ }^{138}\right)$.

Ignoramos se tais visitas se efectuaram $\left({ }^{139}\right)$. Em contrapartida, noticia-se pouco depois não terem podido ser satisfeitas as requisições de material de ensino emitidas pelas professoras das escolas infantis, porque a verba respectiva tinha sido reduzida no orçamento, e que as escolas primárias funcionavam, pela maior parte, em casas alugadas $\left({ }^{14 \circ}\right)$.

As condições de frequência escolar eram deploráveis. O professorado, já nessa época, sugeria o recurso à construção «leve», para o que alvitrava a realização de um empréstimo «destinado à construção de casas ligeiras, sempre por empreitada, com a devida fiscalização do Governo....» $\left({ }^{141}\right)$.

Quanto a este aspecto, contudo, o Ministro da Instrução colocará grande ênfase no louvor à iniciativa particular benévola, de poderes locais ou de indivíduos, a favor da frequência do ensino primário: à Câmara Municipal de Aveiro e ao dr. Lourenço Simões Peixinho, presidente da respectiva Comissão executiva, "pela sua obra educativa e pela devotada assistência que têm prestado às escolas oficiais de Aveiro» (142); a diversos particulares, incluindo uma firma ribatejana, por terem oferecido edifícios ou equipamentos $\left({ }^{143}\right)$.

Durante o período em que Sérgio foi responsável pela Instrução Pública as 8 escolas de ensino primário geral criadas, em 31 de Dezembro de 1923, 26 de Janeiro e 4 de Fevereiro de 1924, serão quase todas instaladas em edifícios ofe-

(138) O Século, 8-1-1924.

(139) Sabe-se, pelo contrário, pelo mesmo jornal, de 24-2-1924 ter o Ministro adiado visita idêntica a Évora.

(140) Idem, 30-1-1924.

(141) Idem, 21-2-1924.

(142) Diário do Governo, 2. a série, n. ${ }^{\circ}$ 29, 6-2-1924, p. 447.

(143) Idem, 2. ${ }^{\mathrm{a}}$ série, n. ${ }^{\circ}$ 38, 16-2-1924. 
recidos por particulares tendo como contrapartida a nomeação de professores por eles escolhidos para as regerem. A única que não estava nessas condições ficava dependente da futura aquisição de casa, mobiliário e material de ensino.

O Decreto n. ${ }^{\circ} 9485$, publicado no Diário do Governo, 1.a série, n. ${ }^{\circ}$ 53, de 10 de Março de 1924 mas datado de 18 de Fevereiro do mesmo ano e ainda assinado por Sérgio, reconhecia a gravidade da situação.

No seu preâmbulo afirma-se haver no país inúmeros edifícios escolares em construção já adiantada mas com as obras suspensas devido ao esgotamento das dotações consignadas. Considerava-se urgente concluir os edifícios aludidos, não só com vista a desobrigar o Estado do pagamento de rendas por instalações provisórias de escolas, «algumas em más condições higiénicas», mas ainda para evitar que «a acção do tempo cada vez mais as arruine elevando os encargos para as referidas conclusões». Apontava-se, ainda, a inadiável premência da realização de obras de reparação em muitos outros imóveis, sem o que se correria o risco de encerramento dessas mesmas escolas.

Nestas circunstâncias, e dando prioridade, nos termos legais, à conclusão de obras já encetadas, em prejuízo do início de outras, e tendo em conta o imperativo de reforçar as dotações destinadas a vistorias de edifícios doados, Sérgio determina a anulação de todos os subsídios concedidos para escolas ainda não começadas e a sua devolução no caso de já terem sido entregues.

Ascendia a $529300 \$ 00$ o total de subsídios anulados a Juntas de Freguesia, Câmaras Municipais, à Associação Popular da Paróquia Civil do $3 .^{\circ}$ Bairro de Lisboa, a duas Comissões de Habitantes e à Direcção Escolar Livramentense do 1. ${ }^{\circ}$ de Maio. A esmagadora maioria das entidades afectadas por esta medida localizava-se em concelhos, freguesias e localidades rurais dos distritos de Castelo Branco, Guarda, Leiria, Lisboa, Porto, Beja, Braga, Bragança, Coimbra, Evora, Faro, Santarém, Viana do Castelo, Vila Real e Viseu.

Além de considerar insuficientes para as finalidades previstas na sua anterior concessão, o Decreto citado institui novos critérios na aplicação futura dos subsídios, quer em construções, quer em reparações. Na respectiva distribuição atender-se-ia ao estado de adiantamento da construção, às verbas já gastas e implicadas pela conclusão visada, à importância do edifício quanto à frequência escolar e ao estado das instalações existentes, assim como aos «auxílios materiais e financeiros que as várias entidades ofereçam para as referidas conclusões, diminuindo assim os encargos do Estado»». 
Este último critério, inserindo-se na preocupação governamental de cercear despesas, atenuaria fortemente as possibilidades das zonas mais carecidas de recursos.

$\mathrm{O}$ decreto reservava, ainda, a concessão de subsídios às escolas cujos planos obedecessem às normas técnicas, pedagógicas e higiénicas e cujas obras interrompidas estivessem «em sofrível estado de conservação». Quer dizer que, muito possivelmente, aquelas que estivessem interrompidas há longos anos seriam em definitivo abandonadas, bem como as que se não acordassem com os projectos arquitectónicos oficiais, de problemático acatamento quando se tratava de iniciativas de base popular.

De notar, também que, em contradição flagrante com uma política de compressão de despesas, o mesmo decreto apenas admite o sistema de obras em regime de administração directa (que traria sensíveis economias), no caso de a empreitada não ser adjudicada por falta de concorrentes!

Sem prejuízo de reconhecermos a dificuldade do desenho de uma política correcta numa situação de penúria quase generalizada, é de duvidar que ela não viesse a ferir interesses mais do que legítimos e a redundar, por seu turno, em novas situações de injustiça.

Também no domínio do que então se chamava «assistência escolar» a situação era certamente muitíssimo negativa. Chegava-se ao ponto de crianças portuguesas, em localidades próximas da raia, frequentarem escolas gratuitas de congregações espanholas (144).

De resto, apesar do virulento anti-clericalismo da 1. ${ }^{\mathrm{a}} \mathrm{Re}-$ pública, o ensino particular confessional estava longe de ter desaparecido. Esse facto levou o deputado Almeida Ribeiro a chamar a atenção do Ministro da Instrução, que se não achava presente, para o funcionamento, em Évora, de colégios dirigidos por congreganistas, não só porque o considerava contrário à lei da separação mas ainda porque, vivendo esses colégios de esmolas e subsídios, e dirigidos por irmãs da caridade, podiam praticar preços inferiores aos dos colégios laicos $\left({ }^{145}\right)$. Embora sob a mira de promover a educação religiosa das crianças, é altamente provável que tais colégios desempenhassem ampla função assistencial nas circunstâncias prevalecentes durante aquele período.

\footnotetext{
(144> O Século, 13-1-1924. p. 27.

(145) Diário da Câmara de Deputados, Sessão n..$^{\circ}$ 34, 11-2-1924,
} 
$A$ verdade é que a acção estatal se revela particularmente frouxa no plano da «assistência escolar». O carácter pontual e precário das decisões adoptadas neste domínio bastaria, só por si, para o comprovar.

Assim, quanto à assistência médica escolar, aproveitam-se os postos da antiga linha férrea da Buraca e de Alcanfins, cedidos pelo Ministro das Finanças ao da Instrução, para neles serem instaladas «escolas ao ar livre e outras obras de assistência médica escolar», de cuja organização e direcção ficara encarregada a Junta de Sanidade Escolar (146). Ou então, nomeia-se médico oftalmologista do Liceu de Passos Manuel, o médico escolar do mesmo estabelecimento, Joaquim Fernandes de Brito Camelo de Gouveia, sem direito a remuneração alguma pelo exercício das funções mas com a obrigação de examinar «todos os alunos das escolas primárias e secundárias de Lisboa que lhe forem enviados pelos médicos escolares da mesma cidade» $\left({ }^{147}\right)$.

No respeitante à educação física das crianças é de crer que, nas condições evocadas, não tivesse lugar nas escolas primárias, nem, tão-pouco, em muitos liceus. Não vemos nós o louvor concedido por Sérgio ao professor de educação física do Liceu Nacional de Fernão de Magalhães, em Chaves, João Femandes Azevedo, por ter patenteado excepcional interesse pela cultura física dos alunos, chegando a ceder um salão da sua residência para a realização de exercícios ginásticos visto que o liceu não dispunha de local apropriado? $\left({ }^{148}\right)$.

Visivelmente, procurava-se estimular por todos os modos a iniciativa benévola, atenta a incapacidade do Estado para assegurar as condições materiais adequadas a uma acção educativa integral.

Quanto ao estudantado do ensino superior, Sérgio concederá uma casa destinada a Residência de Estudantes. Correspondia, desse modo, à iniciativa de dois académicos, José Maria de Brito Paiva e Fernando Calado, que tivera o beneplácito do Presidente da República. Obtida a instalação, seriam precisas obras, apelando-se, mais uma vez, para o concurso das boas almas $\left({ }^{149}\right)$.

(146) A Batalha, 29-1-1924.

(147) Diário do Governo, 2. a série, n. ${ }^{\circ}$ 30, 7-2-1924, p. 466.

(148) Idem, ibidem, n. ${ }^{\circ}$ 26, 1-2-1924, p. 402.

("') Diário de Lisboa, 29-1-1924 e O Século, 28-1-1924. 
Sérgio e as reivindicações do professorado

A situação do professorado, em especial a dos docentes do ensino primário, revestia igualmente grande gravidade.

Todo o período em que Sérgio está no Governo seria caracterizado por uma relativa inoperância perante o carácter concreto e premente das reivindicações dos professores. Essas reivindicações caracterizam uma conjuntura típica de crise aguda.

Um dos seus aspectos é realçado pelo deputado António Correia, que chama a atenção do ministro, em Fevereiro, para o facto de os professores de instrução primária não terem conseguido receber os seus vencimentos, o que os colocava numa situação que qualifica de "verdadeira miséria». Também $O$ Século, pela mesma ocasião, dirá que os professores interinos (eventuais) não recebiam vencimentos desde Outubro-Novembro $\left(1^{\circ}\right)$.

As reivindicações dos interinos tinham o seu peso particular. Providos no ensino primário geral para escolas vagas ou encerradas por motivos de doença, nos termos da lei n. ${ }^{\circ} 432$, de 14 de Setembro de 1915, foram nomeados em muito maior número, pelo menos durante o período de que nos ocupamos, do que os efectivos. Assim, entre 18 de Dezembro de 1923 e 28 de Janeiro de 1924 recenséamos 26 professores providos em definitivo, segundo o art. $^{\circ} 92 .^{\circ}$ do Regulamento do Ensino Primário Normal de 29-9-1919, ao passo que entre aquela primeira data e 22 de Fevereiro de 1924 se nomeiam 1283 interinos.

As reivindicações dos interinos cifravam-se na obtenção de subsídio de renda de casa como os efectivos, melhoria de vencimento e outras regalias, bem como na concessão do visto, para efeitos de vencimentos, pelas Juntas Escolares (organismos parcialmente eleitos, ao escalão concelhio) e não pelo Conselho Superior de Finanças e pelo poder central, evitando-se, desse modo, os verificados atrasos de pagamento (151).

Outra categoria específica de reclamações tinha a ver com os directores das escolas primárias da capital e com os professores dos cursos nocturnos, que não obtinham deferimento para os requerimentos em que solicitavam as gratificações que lhe eram devidas nos termos do art. $26 .^{\circ}$ da lei n. ${ }^{\circ} 1452$ de 20 de Julho de $1923\left({ }^{152}\right)$.

$\left.{ }^{150}\right)$ Diário da Câmara dos Deputados, Sessão n. ${ }^{\circ}$ 38, 18-2-1924 e O Século, 24-2-1924.

(151) O Século, 17-2-1924.

(152) Idem, 2-2-1924. 
Novo aspecto do panorama reivindicativo era a questão dos diplomados sem colocação. $\mathrm{O}$ art. ${ }^{\circ} 35$. $^{\circ}$ do decreto n. ${ }^{\circ} 9223$ permitia aos professores do ensino primário que não dispusessem de instalação para o funcionamento da sua escola serem colocados noutro estabelecimento onde fizessem falta. Os professores no desemprego reclamavam no sentido de se obterem as instalações escolares necessárias, porque, diz a Imprensa, «com o aumento constante das escolas em mau estado, cada vez se lhes torna mais difícil a colocação, por não serem postas a concurso as escolas regidas temporariamente por aqueles professores em comissão» (153). A sugestão, de que nos fizemos eco, do recurso a «casas ligeiras» terá aqui, por certo, uma das razões determinantes.

O sindicalismo docente, no sector do ensino primário, pugnava pela solução dos problemas globais da classe. «A Comissão Executiva do Professorado Primário, escreve $O$ Século poucos dias antes da exoneração de Sérgio, tem continuado a instar junto do novo ministro da Instrução pelo cumprimento das reclamações que tem feito aos anteriores ministros que não as puderam satisfazer pela sua curta duração no poder». O jornal identificava-as sucintamente: estabelecimento de folhas provisórias para que não sofresse demora o pagamento dos vencimentos; dispensa de «visto» nos decretos de nomeação dos professores interinos e temporários; lei que reestruturasse o quadro dos professores primários da capital e de outras localidades; emendas ao decreto n. ${ }^{\circ}$ 9223, como já fora proposto pela Comissão; estabelecimento de pensão condigna aos docentes em inactividade; pagamento adiantado das verbas de expediente e limpeza das escolas; autonomia financeira das Juntas Escolares, sem a qual, especificava-se, «os edifícios escolares dentro em breve se não poderão utilizar»; exoneração do director da secção masculina do Instituto do Professorado Primário, por não pertencer àquele grau de ensino, «nomeando-se professor competente da classe, sendo o demais pessoal também constituído por professores primários»; actuaiização dos subsídios de residência e rendas de casa do professorado primário; criação das escolas primárias necessárias nas localidades que ainda não as possuíssem e, finalmente, o direito à negociação e ao diálogo, isto é, «que as modificações a fazer nas leis e regu-

(153) Idem, 12-2-1924. 
lamentos do ensino primário se não façam sem que o professorado primário seja ouvido»? $\left({ }^{154}\right)$.

A Imprensa fazia-se ocasionalmente eco de outras aspirações da classe docente: reivindicações de que o serviço obrigatório dos professores primários passasse apenas de 24 para 30 horas, e não para 36, revogação da lei 1246 e criação de uma prova de exame da $4 .^{\mathrm{a}}$ classe dando direito a admissão ao secundário, primário superior, elementar técnico e artístico $\left({ }^{155}\right)$.

Que medidas concretas tomou Sérgio em relação a este vasto acervo de problemas? Que projectos terá alimentado a esperança de realizar?

Algumas dessas disposições visam, claramente, «disciplinar» o professorado.

Em primeiro lugar, pelo decreto $n .^{\circ}$ 9471, determinava aos directores de todos os estabelecimentos de instrução pública o rigoroso cumprimento das normas contidas na lei orçamental n. ${ }^{\circ} 403$, de 9 de Setembro de 1915, que regulava minuciosamente o regime de vencimentos, gratificações, faltas, licenças, etc. E, pela mesma ocasião, estatuirá que os directores de todos os estabelecimentos dependentes do Ministério enviassem com a maior urgência às respectivas direcções gerais, uma nota dos funcionários providos em mais de um cargo oficial e quais as localidades e estabelecimentos em que exerciam ou deveriam exercer essas funções $\left({ }^{156}\right)$.

A preocupação de eliminar situaçõ̂es irregulares ou acumulações indevidas é acompanhada, pouco depois, de determinações que parecem destinadas a satisfazer reivindicações da Uniăo do Professorado Oficial quanto ao decreto n. ${ }^{\circ}$ 9223, de 6 de Novembro de 1923 e que a Imprensa $\left({ }^{157}\right)$, em Janeiro, noticiava não terem ainda sido atendidas. Tratava-se da questão de licenças por doença ou incapacidade.

O Decreto n..$^{\circ} 9408$, de Fevereiro, revogava o art. ${ }^{\circ} 51 .^{\circ}$ do citado decreto e dava nova redacção a outros artigos. Quanto ao $57 . .^{\circ}$, estabelecia-se que os professores fora do exercício de funções por motivo de doença não poderiam ausentar-se da área da sua residência oficial, sob pena de imediata

(164) Idem, 26-2-1924. O caso do director do Instituto do Professorado Primário punha em foco o professor Joaquim^^${ }^{\wedge}$ Correia Salgueiro, cuja nomeação como efectivo do Liceu de Camões em Lisboa já fizera escândalo, acabando por ser considerada legal (Cf. Diário da Câmara de Deputados, sessão n. 13, 19-12-1923, pp. 3-4).

(155) O Século, 25-1-1924 e 2-2-1924.

(156) Diário do Governo, l.a série, n. ${ }^{\circ}$ 50, 6-2-1924, p. 349; idem, 2. ${ }^{a}$ série, n. ${ }^{\circ}$ 28, 4-2-1924, p. 433.

(167) O Século, 25-1-1924. 
perda de vencimento e de sujeição a processo disciplinar por abandono de funções. Exceptuavam-se da primeira parte do artigo os docentes cuja doença, verificada e comprovada, carecesse de tratamento especial fora daquela área ou distrito. Esse tratamento deveria ser aconselhado, por escrito, sob compromisso de honra pelo médico assistente, devendo porém tal prescrição ser confirmada pelo médico escolar ou seu substituto, ou ainda pela Junta de Sanidade Escolar.

$\mathrm{O}$ decreto estipulava igualmente as modalidades de controlo destas situações, regulamentava os casos de afastamento do serviço por doença ou incapacidade física, a concessão de licenças por doença e o seu controlo pela Inspecção Geral de Sanidade, médicos escolares ou seus substitutos, devendo, para as licenças até 30 dias, haver informações sobre a assiduidade do requerente. Para as licenças de mais de 30 dias, seria indispensável o parecer da Junta de Sanidade Escolar, havendo direito de recurso para uma Junta especial, em que figurariam professores da Faculdade de Medicina de Lisboa, cabendo ao interessado o pagamento antecipado dos honorários desses vogais e dos dois restantes que seriam médicos escolares indicados pelo Ministério $\left({ }^{158}\right)$.

Tais dispositivos mais parecem destinados a apertar o controlo sobre a concessão de licenças por doença (e provavelmente a evitar abusos) do que a eliminar situações de injustiça. O certo é que as Juntas de Sanidade Escolar continuarão a conceder licenças por doença ao longo de todo o período em que Sérgio foi ministro, num total que, sem exagero, podemos computar em cerca de 2000 dias só para o ensino primário!

Também sobre este problema a aeção de Sérgio é débil. No plano da assistência na doença aos professores do mesmo grau de ensino, tem-se conhecimento de que o Ministro da Instrução Pública solicitou ao seu colega das Finanças a cedência do edifício do antigo posto de Vale do Forno. A Inspecção de Sanidade Escolar tencionava organizar aí um serviço destinado ao tratamento dos docentes do ensino primário que carecessem de submeter-se a uma cura de repouso ${ }^{(159)}$. Não temos, porém, mais notícias desse plano.

Sabemos pela Seara Nova ter o Ministro encarregado a Comissão Pedagógica de estudar, entre o desempenho de outras tarefas, as reclamações do professorado primário $\left({ }^{16 \circ}\right)$. Ë difícil apurar se esse estudo terá chegado' a concluir-se.

(15s) Diário do Governo, l.a série, n. ${ }^{\circ}$ 27, 6-2-1924, pp. 217-218. (159) A Batalha, 29-1-1924.

(160) Seara Nova, (31), 15-2-1924, p. 132. 
Contudo, resultou da acção de Sérgio, pelo menos, a elaboração de uma proposta de lei, entregue ao seu sucessor, visando resolver o problema do pagamento aos professores interinos do ensino primário, que diz ter vindo achar em grande atraso. Sérgio confessa não ter tido tempo "de remover as dificuldades burocráticas que se opunham à solução rápida dessa triste situação» $\left({ }^{161}\right)$.

Ainda em relação ao professorado, Sérgio terá o cuidado de regulamentar o artigo $5 .^{\circ}$ da lei n. ${ }^{\circ} 410$, de 31 de Agosto de 1915. Determinava esse artigo não poder ser provida «em qualquer cargo dos estabelecimentos de ensino, seja qual for o ramo de instrução, nem ser inscrita no professorado livre, qualquer pessoa que não tenha provado, por actos e factos, a sua franca adesão às instituições republicanas»».

Esta nova regulamentação visava simplificar o processo e eliminar eventuais arbitrariedades na aplicação prática. Assim, tal prova seria exigível apenas quando se tratasse de pessoas que não exercessem ainda cargo público oficial, por meio de atestado passado nos precisos termos do mesmo artigo pelo administrador do concelho ou bairro onde residisse o interessado. Para os indivíduos que já exercessem cargo público oficial, o atestado seria substituído por declaração escrita, devidamente autenticada, do superior hierárquico sob cujas ordens estivessem prestando ou tivessem prestado serviço. Quando qualquer dessas entidades se recusasse a passar o atestado ou a declaração exigíveis, deveria concretizar por escrito no requerimento os factos em que fundamentava a recusa. Finalmente, o decreto estabelecia que nenhuma nomeação se efectuaría, nem nenhum diploma de professor do ensino livre poderia ser conferido sem que junto aos respectivos processos figurasse o documento citado $(162)$.

Deste modo, é visível ter Sérgio pretendido essencialmente minorar efeitos negativos na aplicação da lei, quer devido às demoras burocráticas inerentes, quer devido à recusa discricionária da passagem de atestados ou declarações $\left({ }^{183}\right)$.

(161) Idem, (34), 9-4-1924, p. 196.

(162) Decreto n. ${ }^{\circ} 9412$, in Diário do Governo, $1^{a}$ série, $^{\circ}{ }^{\circ} 28$, 7-2-1924, p. 237. O ensino «livre» é, ao tempo, a designação dada ao ensino particular.

(1€3) Foram, por isso mesmo, caluniosas e confusionistas as acusaçôes de Trigo de Negreiros a Sérgio, assacando-lhe a paternidade de uma lei que se limitou a regulamentar, atenuando, ainda assim, as incidências negativas que poderia ter na sua aplicação. Sobre estes assuntos, ver: Jacinto Baptista, «Cartas inéditas trocadas entre António Sérgio e João Sarmento Pimentel», in O Ponto, 27-5-1982 e «A questão da índia Portuguesa apreciada por Antonio Sérgio ${ }^{\wedge}$ em 1954», idem, 3-6-1982. 
No sector do ensino primário, como em relação a todo o sistema de ensino, são francamente insuficientes os resultados práticos da intervenção de Sérgio em ordem a atender as reivindicações mais urgentes e imediatas do professorado.

\section{Por uma nova pedagogia e organização do ensino primário}

Tal facto depõe sobre o tipo de prioridades que elegeu, neste campo como em todos os demais. A sua preferência pelo que chamava «questões pedagógicas» era directa consequência da sua estratégia de reestruturação do sistema de ensino.

Em matéria de instrução, diria Sérgio na passagem da pasta a Hei der Ribeiro, «o que mais importa é a formação de professores e a existência de escolas modelares ou experimentais, donde parta para as outras o exemplo e o impulso reformador....» $(164)$.

Além dos seus planos de envio de bolseiros para o estrangeiro e de criação de escolas experimentais, Sérgio tomaria outras iniciativas de renovação pedagógica e avançaria para projectos de reforma no âmbito do ensino primário geral.

A primeira em data está inserta numa portaria de 23 de Janeiro de 1924. Reconhecendo «da maior conveniência pedagógica difundir pelo professorado primário instruções sobre a aplicação dos modernos jogos para aprendizagem da leitura», estabelecia-se que Alberto Pimentel e João da Silva Correia, respectivamente professores de pedagogia geral e de língua e literatura portuguesa da Escola Normal Primária de Lisboa, redigissem, «num prazo de tempo que não deveria exceder oito dias», um conjunto de instruçồes, «inspirados mormente nos processos de iniciação da leitura da Dr. ${ }^{\mathrm{a}}$ Montessori e do Dr. Decroly» ( $\left.{ }^{165}\right)$.

Alberto Pimentel e João da Silva Correia desempenham-se brilhantemente do encargo. Tais instruções começariam por ser publicadas na folha oficial através da Portaria n. ${ }^{\circ} 3891$. Considerando da maior importância orientar os professores do grau infantil e primário geral para os processos modernos

(164) Seara Nova, (34)..., cit., p. 195.

(165) Diário do Governo, 2. ${ }^{\mathrm{a}}$ série, n. ${ }^{\circ}$ 19, 23-1-1924, p. 285. Corrige-se, neste ponto, o que escrevemos a p. 78 do nosso estudo $A$ Pedagogia Portuguesa Contemporânea, cit...., em que atribuímos a autoria destas instruções a Alberto Pimentel e a Adolfo Lima. 
de iniciação à leitura e à escrita que aproveitasse principalmente das contribuições didácticas de Montessori e de Decroly, com tanto êxito no ensino das crianças anormais, dizia-se que tais processos permitiriam, «pelo seu carácter intuitivo e marcha psico-pedagógica», combater, «desde o começo do aprendizado escolar, dois vícios gravíssimos da velha metodologia: o psitacismo ou papagueio maquinal de palavras e o verbalismo ou excesso de vazio retórico» (166).

Com a difusão de tais instruções visava-se «começar a tentar-se entre nós, no ensino oficial, uma experiência de que muito há a esperar». Para o seu bom êxito determinava-se ao professorado que requeresse às Inspecções Escolares e às Escolas Normais Primárias o esclarecimento das suas «hesitações ou dúvidas», e, ainda, que comunicasse à Direcção Geral do Ensino Primário e Normal «os resultados dos seus tentames ou aplicações experimentais» $\left({ }^{167}\right)$.

O texto das instruções começava por assinalar o que se designava por «momentos psicológicos do ensino da leitura e da escrita». Indicava o modo de realização de exercícios e os jogos apropriados, na base de uma metodologia de aprendizagem global que partia da palavra (ou até da frase) para a sílaba e o fonema ou sinal e, finalmente, para a denominação da letra $\left({ }^{168}\right)$.

Tratava-se, obviamente, de uma inversão completa da metodologia de ensino da leitura e da escrita mais divulgada entre nós. À dificuldade que o professorado do ensino primário enfrentaria por certo na sua aplicação, acrescia um outro óbice. Pode-se dizer que, na quase totalidade, os jogos didácticos pressupunham a existência de um material que, não obstante a sua rudimentaridade, as escolas não sabiam, nem poderiam produzir, devido à escassez de verbas.

Deste modo, nova Portaria viria tentar obviar a essa dificuldade. Nesse documento atribuia-se às Escolas Normais Primárias um papel activo no que chamaríamos formação permanente do professorado primário de todos os graus, qualificando-as de "constantes e activos centros de orientação». Dispondo tais estabelecimentos de aulas de trabalhos manuais em que era possível executar-se material didáctico, estatuia-se que nelas se construísse «com a maior brevidade possível o material-tipo para os jogos de leitura e de escrita» que tinham sido objecto das instruções referenciadas $\left({ }^{169}\right)$.

(16e) Diário do Governo, l.a série, n. ${ }^{\circ}$ 25, 2-2-1924, p. 207.

C67) Idem, ibidem.

$\mathrm{O}^{68}$ ) Idem, ibidem, pp. 207-210.

T68) Idem, 1. . série, n. ${ }^{\circ}$ 25, 15-2-1924, p. 289. 
É difícil averigụar a medida em que tal encargo poderia passar à prática. E bem possível que as Escolas Normais Primárias se não salientassem por uma acção relevante quanto ao ensino de tais disciplinas. Caso contrário, a organização de exposições de trabalhos manuais escolares não deveria ser tão excepcional nas escolas primárias que merecesse louvor no Diário do Governo. E todavia é esse o objectivo de uma portaria de Sérgio, que distingue o corpo docente da escola central do ensino primário geral de Silves «pela boa vontade, competência e zelo manifestados»» na preparação de exposições de trabalhos manuais no termo dos anos lectivos de 1921-1922 e $1922-1923\left({ }^{170}\right)$.

Por outro lado, seria duvidoso que o professorado do ensino primário não carecesse, para os efeitos da inovação metodológica pretendida, de apoio directo mais eficaz.

Durante o período em que Sérgio desempenhou funções ministeriais, seria aprovada uma verba de 50 OOOfOO destinada a inspecções a escolas de ensino primário geral e infantil. Que se não tratava de uma acção maciça de apoio ao corpo docente em exercício com vista à difusão da nova metodologia de ensino patenteava-se pelo facto de se determinar que os inspectores visitassem de preferência as escolas que não tinham sido inspeccionadas no ano anterior e remetessem no prazo regulamentar o relatório e mapas estatísticos a que estavam obrigados por imposição legal ( $\left.{ }^{171}\right)$.

Os quadros da inspecção seriam, certamente, insuficientes e, com toda a probabilidade, impreparados para a implementação de inovações pedagógicas com as quais não teriam grande familiaridade prática $\left({ }^{172}\right)$.

Mais do que numa acção directa de apoio, para a qual não dispunha de meios apropriados, o Ministro seareiro lançará mão do material escrito. Daí deriva a edição de um $B o-$ letim Pedagógico, em que são republicadas as instruções elaboradas por Alberto Pimentel e João da Silva Correia, e cuja criação obedecera «à conveniência de fornecer aos professores informações de carácter prático, concretas, facilmente

(170) Idem, 2. a série, $n .^{\circ} 13,16-1-1924$.

(171) Decreto n. ${ }^{9467}$, in Diário do Governo, 1.a série, n. ${ }^{\circ} 49$, 3-3-1924, pp. 343 e ss. Em anexo procedia-se à repartição das verbas por regiỗes do Continente e Ilhas.

(172) Havia casos de exercício de lugares de inspeç̧ão por professores, a título interino. Veja-se o louvor a Joaquim Pedro Dias, «pela competência, zelo e inteligência com que desempenhou o cargo de inspector interino do círculo escolar do $30^{\circ}$ bairro de Lisboa»" (Diário do Governo, 2.a série, n. ${ }^{\circ} 29,6-2-1924$, p. 447). 
utilizáveis, sobre novos processos de ensino de que lhes é difícil ter notícia, já pela actual carestia de todas as obras estrangeiras, já pelo obstáculo que a maioria encontra no $1 \mathrm{er}$ o inglểs e o alemão». Era sua intenção, acrescenta Sérgio, que o segundo número viesse explicar «a organização e funcionamento das sociedades escolares florestais») e que o terceiro expusesse "algumas modernas directivas do ensino primário e secundário das ciências naturais» (173).

No mesmo âmbito de intenções se filiavam as instruções dadas ao cônsul de Portugal em Londres no sentido da aquisição dos direitos de tradução das Object Lessons, de Murché, «cuja difusão entre os professores primários, acrescenta, deveria dar um grande impulso à tão necessária modernização da técnica pedagógica entre nós» $\left({ }^{174}\right)$.

\section{Criação do «cinema educativo»}

Outra inovação de carácter pedagógico-didáctico introduzida por Sérgio tem a ver com a utilização do cinema educativo. Projectava o ministro difundido não só nas escolas oficiais mas também nas Universidades populares, onde o recurso à imagem fixa já era corrente desde os começos do século.

Sérgio trabalhou na organização de um serviço de «sessões cinematográficas instrutivas». Essa ideia apoiava-se na iniciativa particular, anunciando-se até que um dos amigos do Ministro se achava no estrangeiro a tratar do assunto e que dentro em breve começaria a circular por várias escolas uma máquina Pathé-Baby com fitas instrutivas (175).

$\mathrm{O}$ «cinema instrutivo» viria a concretizar-se, pelo menos parcialmente, na escola portuguesa, devido à oferta feita pelo sr. António Joaquim Moquenco, ao Museu Pedagógico da Junta de Orientação dos Estudos - ainda inexistentes de facto - de, precisamente, uma Pathé-Baby. A oferta vale-lhe um louvor na folha oficial, pelo seu «alto significado cívico» e pelo in-

(173) Seara Nova, (34)..., cit., p. 126.

(174) Idem, ibidem, pp. 195-196. Sérgio já conhecia e recomendava essa obra desde há anos, como se vê por uma carta remetida do Rio de Janeiro a Silva Gayo, e datada de 1920. (Arquivo..., cit., p. 354). O livro só em 1925 virá a ser publicado, em tradução e adaptação de José Rodrigues Miguéis, com prefácio de Sérgio. Cf. A Pedagogia Portuguesa Contemporânea..., cit., p. 97 e p. 157.

(175) O Século, 5-2-1924. 
teresse do oferecimento para «os modernos processos de ensino» $\left({ }^{176}\right)$.

A «l. ${ }^{a}$ sessão de fitas instrutivas» ter-se-á realizado na escola oficial n. ${ }^{\circ} 28$ da Rua da Palma, pertencente ao ensino primário geral, segundo O Século de 21 de Fevereiro de 1924. Atendendo a que o jornal se publicava de manhã, terá ocorrido na véspera, senão a primeira, pelo menos uma das primeiras exibições de cinema educativo no ensino oficial português.

A utilização deste meio didáctico não era, contudo, tema pacífico (177). Assim, poucos dias depois dessa primeira sessão, anunciava-se uma próxima consulta à Inspecção de Sanidade Escolar sobre o carácter eventualmente prejudicial do cinema instrutivo, dado que, acrescentava-se, noutros países já se pusera de parte! (178).

De todos os modos, Sérgio não abandona o projecto. $\ddot{E}$ o que se deduz da informação prestada ao seu sucessor de que criara «um serviço especial de cinematógrafos circulantes, com fitas instrutivas», com base na máquina de projecção oferecida, e de que trabalhava «na organização de uma sociedade particular de indivíduos beneméritos, para aquisição de aparelhos e fitas, e sua distribuição pelas escolas e universidades populares», no que também estaria interessado, especifica, o sr. José de Matos Braancamp (179).

Sérgio considerava sem dúvida o ensino primário como um elemento fulcral da «reforma da mentalidade», pré-requisito, no seu pensar idealista, da «reforma social».

Nessa linha de orientação, de que boa parte dos seus anteriores trabalhos de pedagogia constituíam suporte teórico, dirá pretender «remodelar» a escola primária, «no sentido de a ligar o mais possível com o trabalho profissional da região e com as necessidades do nosso povo», e «instituir» a educação cívica, «pela República Escolar e pela organização corporativa dos grupos de estudantes» $\left({ }^{180}\right)$. ${ }^{* 34}$

(176) Diário do Governo, 2.a série, n. ${ }^{\circ}$ 39, 18-2-1924, p. 602.

(w) Veja-se o nosso estudo Para a história dos meios audio34, 1969, pp. 14 e ss.

-visuais na escola portuguesa, sep. da Revista de Portugal, série A, vol.

(',8) O Século, 24-2-1924.

(179) Seara Nova, (31), 15-2-1924, p. 132 e (34)..., cit., p. 196.

(180) Idem, (30), 31-1-1924, p. 114. Apesar disso, o ministro seareiro não deixará de recorrer aos meios clássicos de educação pelo exemplo e não pela prática. Assim, mandaria dar o nome do «glorioso marinheiro Patrão Joaquim Lopes», «exemplo nobilissimo de virtudes morais, de abnegação e de sacrifício» às escolas de ensino primário geral de Paço d'Arcos (Diário do Governo, l.a série, n. $.^{\circ} 35,15-2-1924$, p. 289). 
Embora Sérgio não tenha chegado a avançar para o projecto da escola primária rural, sabe-se ter pedido a Azevedo Gomes, então na pasta da Agricultura, que encarregasse um agrónomo de elaborar indicações sobre as sociedades escolares florestais. Destinar-se-iam tais instruções a ser difundidas entre os professores do ensino primário, prevendo-se a concessão de um prémio aos que se distinguissem quanto ao funcionamento de tais sociedades (181).

Sob o ponto de vista da organização deste grau de ensino, deixou Sérgio em projecto algumas disposições de que se desconhece a feição concreta. Todavia, afirma a Helder Ribeiro estar redigido e a ser cuidadosamente ponderado um novo regulamento dos serviços do ensino primário. Sob o ponto de vista administrativo adoptava uma perspectiva mista de descentralização e desconcentração, já que consultara os municípios sobre a eventualidade de se encarregarem da administração deste grau de ensino, «fornecendo o Estado mensalmente os fundos necessários para pagar ao pessoal, e dispondo os municípios das verbas dos seus orçamentos destinadas a rendas de casas para escolas, mobiliário, material didáctico, e conservação e reparação dos edifícios escolares»». As importâncias fornecidas pelo Estado proviriam da contribuição de $32 \%$ para o fundo de instrução primária, nos termos do art. ${ }^{\circ} 6$. $^{\circ}$ da lei de 21 de Setembro de 1922, num regime de «cuidadosa fiscalização do Estado» $\left({ }^{182}\right)$.

\section{Os ensinos normal e artístico}

Quanto ao ensino normal primário sabe-se ter encarregado a Comissão Pedagógica de estudar a criação de cursos de aperfeiçoamento mas tais trabalhos não parecem ter desembocado em resultados dignos de menção $\left({ }^{183}\right)$.

O ensino artístico não receberá da parte de Sérgio nenhum impulso particular.

Os programas do Conservatório Nacional de Música serão publicados e a seguir rectificados na folha oficial. São postos a concurso dois lugares de pensionistas do Estado, no estrangeiro, um da classe de violoncelo, outro de composição ${ }^{184}$ ). A tão pouco se resume a sua intervenção neste domínio.

(181) Idem, ibidem, pp. 112-113.

(152) Idem, p. 195 e p. 196.

(183) Idem, (31)..., cit., p. 132.

(184) Diário do Governo, l. ${ }^{\mathrm{a}}$ série, n. ${ }^{\circ}$ s 10 e 29 , de 15-1-1924, e de 8-2-1924; idem, $2 .^{a}$ série, $n .^{\circ} 21,25-1-1924$. 
Primeiros ensaios do «ensino especial»

Sérgio procurou intervir a fundo no âmbito da estrutura do aparelho do Estado no sentido de responder a carências determinadas do sistema de ensino, aos níveis executivo, de concepção e planeamento, de controlo e avaliação.

Além do novo serviço de cinema educativo e não obstante os seus termos precários, deve-se ao autor dos Ensaios a primeira tentativa de criação de ensino especial para deficientes e de um serviço correspondente no âmbito do Ministério da Instrução.

Com efeito, considerando «de urgente necessidade organizar em Portugal a assistência aos anormais escolares» e a existência, «em avultado número», nas escolas dependentes do Ministério, de alunos que «os médicos escolares reputam prejudiciais ao regular aproveitamento das escolas que frequentam», Sérgio constitui uma comissão junto da Inspecção Geral de Sanidade Escolar, com o encargo «de estudar a forma de organizar essa assistência e de a dirigir, depois de ser superiormente aprovada e decretada a proposta que sobre o assunto elaborar».

Tal comissão era constituída pelo dr. Sebastião Cabral da Costa Sacadura, inspector-geral de Sanidade Escolar, dr. José Guilherme Pacheco de Miranda, médico chefe da secção primária da mesma Inspecção, Fernando Palvart Pinto Ferreira, director pedagógico do Instituto Médico-Pedagógico da Casa Pia de Lisboa, e, finalmente, dr. Vitor Hugo Moreira Fontes, médico do mesmo Instituto $\left({ }^{185}\right)$.

O objectivo da Comissão, a que a Seara Nova chamava «dos Anormais Escolares», seria fazer as crianças «anormais» ingressarem nas aulas existentes no Instituto de Santa Isabel da Casa Pia. Pouco depois, a mesma revista inscrevia no activo do Ministério da Instrução a criação do serviço de assistência aos anormais de idade escolar (186).

$\mathrm{O}$ relatório da Comissão, embora datada de 12 de Fevereiro de 1924, só viria a ser publicado no Diário do Governo dez dias depois.

A comissão, evocando algumas experiências realizadas, e tidos em conta os recursos disponíveis, considera fácil a empresa a tentar, com vista a prestar assistência, de mo-

(185) Diário do Governo, 2. a série, n. ${ }^{\circ}$ 17, 21-1-1924, p. 255.

(186) Seara Nova, (30), cit, p. 112, e (31)..., cit., p. 132. 
mento, a uma pequena parte das crianças anormais, mas com tendência a atingir a grande maioria delas, diz a Comissão, «em curto espaço de tempo, quando todos os serviços estiverem bem organizados e encaminhados» (187)-

O plano da Comissão consiste, simplesmente, na criação de classes especiais junto das escolas primárias públicas, as quais não necessitam, acrescenta-se, de aparelhagem, de mobiliário excepcionais, de material didáctico dispendioso ou de não fácil realização pelos professores e alunos.

Entende também a Comissão ser igualmente fácil a preparação* do professor, «tanto mais que é lícito supor, por fundamento legal, que ele tenha os conhecimentos necessários para a regência dessas novas classes a estabelecer»». Não havendo essencial diferença entre a pedagogia das classes regulares e das especiais, considera-se bastante a passagem do professor, durante poucos dias e para fins de aperfeiçoamento, pelo Instituto Médico-Pedagógico da Casa Pia.

A selecção das crianças destinadas às classes especiais também não apresentaria dificuldades. Ninguém melhor do que o professor, afirma-se, poderia efectuá-la com base no insucesso escolar das crianças. Um aluno, lê-se no relatório, «com frequência regular, com uma demora de dois anos numa classe, por exemplo, sem aproveitamento, quando o professor é pontual e trabalhador, e os demais aproveitam, não necessita, para a determinação da sua inferioridade, nem de Binet-Simon, nem de Treves-Saffiotti, Healy, Porteus ou quaisquer outros, ou aparelhos custosos»».

A Comissão relegava para mais tarde o estudo de institutos médico-pedagógicos e de serviços especializados, julgando-os incompatíveis com a situação financeira nacional, propunha a entrega da assistência às crianças anormais à Inspecção Geral da Sanidade Escolar e ao Inspectorado Primário e terminava preconizando a instituição de classes especiais como programa de praticabilidade imediata $\left({ }^{188}\right)$.

Sérgio concordará com o relatório - o qual, todavia, envolvia o perigo de uma selecção empírica e altamente discutível da criança «anormal», conforme viria a demonstrar a prática ulterior das classes especiais - e decide tornar permanente a mesma Comissão a fim de se encarregar de tal serviço $\left({ }^{189}\right)$.

(18T) Diário do Governo, 2a série, n. ${ }^{\circ}$ 43, 22-2-1924, p. 683.

(188) Idem, ibidem, pp. 683-684.

$\left.\mathrm{C}^{89}\right)$ Seara Nova, n. ${ }^{34 . . .,}$ cit., p. 195. 


\section{Projectos de reforma do Ministério da Instrução}

Quanto aos órgãos superiores do Ministério e às suas relações com o funcionalismo, a intervenção de Sérgio caraoteriza-se igualmente pela tentativa de inovações pontuais e pelo projecto de reformas de estrutura.

Muito cedo reconheceu Sérgio as dificuldades de funcionamento da máquina burocrática do Ministério da Instrução Pública. "A actual organização dos serviços.... parece que visa propositadamente a não deixar trabalhar a sério, opinará junto do seu sucessor. O Ministro só pode trabalhar de manhã: de manhã, porém, não estão no ministério os funcionários; à tarde tem o Ministro Parlamento: há no ministério os funcionários mas não há Ministro. Conviria, creio eu, acrescenta, ritmar a vida oficial pela vida civil, fixar a entrada do pessoal às 10 horas (suponhamos) saída para lanche das $12 Y_{2}$ às 2, e saída definitiva pelas 6». Preconiza também alterações ao nível da própria estrutura do Governo, com a existência de subsecretários de Estado que não só substituissem o Ministro no Parlamento durante os debates menos importantes como evitassem a subida à sua decisão das «questiúnculas mais pequenas, com perda do tempo considerabilíssimo, e prejuízo muito grave para a continuidade na execução da lei» $\left({ }^{190}\right)$.

Por outro lado, sob o ângulo político, o Ministério da Instrução Pública não estava imune de parcialidades e subjetivismos interpessoais. Em resposta a observações do deputado António Correia que lhe censurava a nomeação de um sindicante, Sérgio não vacilará em dizer: «....um indivíduo que entra para um Ministério pela primeira vez, e desconhece as questões pessoais e de facção que lá se passam, pode ser facilmente iludido, e assim praticar um acto no género, que parece ter sucedido comigo»> $\left({ }^{191}\right)$.

Confessaria também, mais tarde, não ter tido tempo para corrigir «vários defeitos administrativos» (192).

Entretanto, através da prática ou de estudos em curso, reconhece-se a sua sensibilidade aos problemas da estrutura funcional ao seu dispor.

E patente o implícito reconhecimento da necessidade de um órgão de concepção e de planeamento ao nível da assessoria ministerial. A Comissão Pedagógica, por ele nomeada,

(1S0) Idem, ibidem, pp. 196-197. pp. 23-24.

(lw) Diário da Câmara de Deputados, sessão n. ${ }^{\circ}$ 21, 16-1-1924,

(1M) Seara Nova, n. ${ }^{\circ} 34 \ldots$, cit.f p. 195. 
era sobretudo um órgão de estudo ao qual confia problemas muito diversos, tais como novos programas, as futuras escolas de continuação, as reclamações do professorado do ensino primário, a administração da instrução primária pelas Câmaras Municipais, a remodelação do Conselho Superior de Instrução Pública, a criação do Inspectorado Técnico do Ensino, a autonomia universitária, os cursos de aperfeiçoamento das Escolas Normais Primárias ( $\left.{ }^{193}\right)$.

Era também sua intenção criar a Inspecção Técnica do Ensino Geral (194) e remodelar o Conselho Superior de Instrução Pública.

Sobre o primeiro daqueles órgãos nada mais sabemos. Acerca do segundo, pretendia dividi-lo em duas Comissões uma Pedagógica e outra Administrativa-, encaminhando-se para esta última a maioria dos casos submetidos, até então, a despacho ministerial (195).

No relatório entregue a Helder Ribeiro, Sérgio precisará melhor o seu ponto de vista. Considerando a impossibilidade de funcionamento do Conselho, o ministro cessante revelava ter redigido uma remodelação desse organismo que não chegara a levar ao Parlamento por desejar que o examinasse em primeiro lugar a Comissão Pedagógica. O Conselho, no projecto de Sérgio, integraria uma secção electiva, que teria em Outubro a sua reunião anual antes da abertura das aulas, e uma secção nomeada e permanente, dividida em duas sub-secções ou comissões: uma administrativa e outra pedagógica. Esta última teria como encargo «ir ajustando de contínuo o funcionamento dos estudos (cumpre abandonar, aditava, a velha ideia das reformas instantâneas e definitivas, legisladas num momento)», ao passo que a primeira solucionaria os casos de «natureza pessoal, burocrática, que hoje ocupam exageradamente a atenção de quem é ministro, tirando-lhe tempo para se consagrar aos negócios gerais do ensino público» $\left({ }^{198}\right)$.

Sérgio procurará também pôr cobro a situações inaceitáveis no Ministério da Instrução, designadamente num período caracterizado pela «austeridade», ou, como então se dizia, pela «compressão de despesas». Desse modo, pouco depois de se ter avistado com a Comissão do Professorado das Es-

(193) Idem, n. ${ }^{\circ} 30$..., cit., p. 132.

(m) Idem, n. ${ }^{\circ} 34, \ldots$, cit., p. 196.

(195) Idem, n. ${ }^{\circ}, \ldots, \ldots$, cit., p. 113.

(196) Idem, n. ${ }^{\circ} 34 . .$. , cit., p. 196. A actividade governativa de Sérgio desdobrar-se-á na verdade por uma sucessão de decisões sobre problemas de maior ou menor alcance. 
colas Primárias Superiores do Norte, que sugeriu a efectivação de «economias» entre o pessoal superior do Ministério, Sérgio apresenta uma proposta de lei que revogaria o art. ${ }^{\circ} 30 .^{\circ}$ e seu $\S$ único do Regulamento respectivo, ficando obrigados à regência de aulas os directores gerais e chefes de repartição que fossem professores de qualquer grau de ensino, e sujeitos, na parte referente a vencimentos, às disposições gerais sobre acumulações $\left({ }^{197}\right)$.

A «racionalização» e «simplificação» dos Serviços (acarretando a passagem de funcionários à situação de adidos) eram, como vimos, um dos pontos programáticos do Governo Álvaro de Castro. No Ministério da Instrução Pública, tal como em outros órgãos do aparelho do Estado, por iniciativa dos ministros seareiros, nomeiam-se «comissões de economias», encarregadas de estudar em concreto o processo de redução de despesas.

Assim, em começos de Janeiro de 1924, anunciava a Seara Nova que, para pôr termo "a sinecuras e imoralidades que há muito vêm sendo objecto de crítica no Ministério da Instrução», seria nomeada uma comissão com o encargo de examinar as despesas daquele sector e as possíveis reduções a fazer. «Não é evidentemente este o caminho que seguem as pessoas que pretendem conquistar a popularidade», acrescentava a revista na antevisão das reacções que tal projecto encontraria (198).

Nos finais do mês a Seara ainda não dava a Comissão por constituída, visto que a Associação Comercial de Lisboa não indicara representante até ao momento. A sua inclusão na Comissão encarregada de propor «os cortes de despesas» devia-se à orientação ministerial de que as "forças vivas», por intermédio de delegados, pudessem verificar, diz a Seara Nova com tranquila ingenuidade, «que o Governo prossegue a sério a obra de saneamento financeiro que empreendeu, a qual lhe dará toda a autoridade moral para impor aos cidadãos (muito especialmente aos que tem mais recursos) aquela parte de sacrifícios que por justiça lhes compete, e que cumpre começar a exigir-lhes o mais brevemente que for possível» $\left({ }^{199}\right)$.

(m) Diário do Governo, 2. a série, n..$^{\circ}$ 38, 16-2-1924, p. 595. Pelo art. ${ }^{\circ} 30 .^{\circ}$ do Regulamento, os funcionários superiores do Ministério acumulavam por inteiro os vencimentos de funcionários e os de professores, sem exercerem a docência, e recebiam como horas extraordinárias aquelas que leccionassem (Seara Nova, (30), ..., cit., p. 113).

(198) Seara Nova, (29), ..., cit., p. 91, e idem, (34),..., cit., p. 192.

(199) Idem, (30), ..., cit., p. 113, e idem, (34),..., cit., p. 195. 
Cuidar que a oligarquia dos banqueiros e «moageiros»» reconheceria na reduçã̃o das despesas do Estado um fundamento de justiça para a aceitação de sacrifícios, sobretudo no momento em que não pagavam ao mesmo Estado as contribuições devidas, como era o caso da Companhia dos Tabacos, é um dos exemplos mais evidentes do idealismo burguês seareiro.

Só em meados de Fevereiro acabaria por ser nomeada a «comissão de economias» do Ministério da Instrução Pública, cujo presidente seria João de Barros, sendo secretário Raul Proença. Moses Bensabat Amzalak figura nessa comissão como representante da Associação Comercial (200).

Sérgio dirá, mais tarde, não ter prosseguido na correcção de anomalias administrativas, nem começado o processo de simplificação de serviços porque cedo se persuadira da conveniência de «atacar esses problemas simultaneamente e em conjunto», ficando a aguardar o relatório da Comissão.

Em relação ao pessoal não-docente, e para além da decisão de reintegração do consultor jurídico do Ministério, que tinha sido colocado igualmente fora do serviço (201), Sérgio tornaria extensiva às empregadas menores do ensino normal primário, primário superior, primário geral e infantil o regime prescrito pelo decreto n. ${ }^{\circ} 7704$, de 7 de Setembro de 1921. Esse decreto dispensava do serviço por espaço de dois meses, durante o último período da gravidez e em seguida ao parto, as professoras do ensino primário, independentemente de serem ou não casadas $\left({ }^{202}\right)$.

Seria, contudo, devido ao pessoal feminino do Ministério que teria de enfrentar uma das mais graves tempestades políticas da sua curta passagem pelo Governo.

$\mathrm{O}$ incidente revestiu sem dúvida aspectos delicados. Mas, tanto a sua exploração na Imprensa, designadamente em $O$ Rebate, propriedade das Comissões do Partido Republicano Português em Lisboa, como em A Batalha, inseria-se na campanha que visava derrubar Sérgio, os demais ministros indicados pela Seara Nova e desacreditar o próprio Grupo seareiro.

Assim, enquanto $O$ Rebate se interrogava: «O Ministério da Instrução feito campo de manobras religiosas?», $A B a$ talha ampliava o assunto acusando Luisa Sérgio, mulher do ministro, católica praticante, de imaginar, «como prolonga-

${ }^{(200)}$ Diário do Governo, 2. a série, n. ${ }^{\circ}$ 38, 16-2-1924, p. 590.

(201) Idem, I' ${ }^{2}$ série, n. ${ }^{\circ} 49,3-3-1924$, p. 343.

(202) Idem, ibidem, 10-1-1924, p. 36. 
mento da sua acção na instituição católica beneficente das 'Florinhas da Rua', um sindicato feminino com bases religiosas»».

Para tal «sindicato feminino», acrescentava o diário, Luisa Sérgio convidara o funcionalismo feminino do Ministério, que o Ministro lhe apresentara no seu gabinete como susceptível de ser pessoal «para um sindicato católico e feminino»».

A Batalha espraiava-se depois em comentários humorescos, afirmando que a família começara «a acrescentar aos aposentos que a constituem mais outro que é simultaneamente cozinha e casa de jantar - o gabinete do ministro com quem se está matrimoniado» $(203)$.

$\mathrm{O}$ assunto seria tratado no Parlamento como «negócio urgente» pelo deputado Sá Pereira, que pertencia ao Grupo Parlamentar de Acção Republicana.

O deputado começaria por criticar que dentro das repartições públicas se fizesse propaganda religiosa, e muito menos no Gabinete de um ministro.

Sérgio explica serenamente do que se tratava. «A obra a que o Sr. Sá Pereira se referiu, dirá, existe em todos os países civilizados; existe em países protestantes e aí teve origem; existe em países católicos. Ë uma instituição que nesses países recebe o auxílio do Estado e dos particulares, e que, entre outras funções beneméritas, protege as raparigas que viajam desacompanhadas, as quais encontram nas gares senhoras que se fazem conhecer por distintivos especiais e que as protejem e guiam, pois, como V. Exas. sabem, a muitos perigos estão expostas as raparigas que viajam sós».

O Ministro afirma, depois, ter visto funcionar essa instituição, sobretudo na Suíça, achando «naturalíssimo» que viesse a funcionar igualmente em Portugal. Não se tratando, porém, de propaganda religiosa mas apenas de uma obra de beneficência, esclareceria, Sérgio toma o compromisso de que tais factos se não repetiriam se acaso feriam os costumes portugueses.

Apesar de agradecer as explicações do Ministro, Sá Pereira continua a referir-se a «missões de propaganda» e a invocar a neutralidade do Estado em relação à religião ou à irreligiosidade.

Colocaria, contudo, em foco vários aspectos do problema de que Sérgio, estranhamente, não parecia ter-se aperce25-1-1924.

$\left(2^{\circ} 3\right) \mathrm{v}_{\mathrm{er}}$, designadamente, O Rebate, 23-1-1924, e A Batalha, 
bido. Convidadas para uma reunião no gabinete do Ministro e pela própria esposa deste, as funcionárias do Ministério sentiam-se coagidas, «visto que no Gabinete do Ministro elas na verdade não se sentiam em condições de aceitar ou repelir com consciência uma proposta que era feita pela esposa do Ministro». Outras funcionárias, cujos contratos teminavam no mês de Maio seguinte, sentir-se-iam igualmente «coactas para se resolver a aceitar urna coisa que porventura não desejavam» $\left({ }^{204}\right)$.

O debate, porém, não tardaría a deslizar para o «republicanismo» de Sérgio, que muitos punham em dúvida, em razão do seu pedido de demissão de oficial da Marinha após 1910. O ministro confessa-se ateu mas possivelmente cristão- o que origina surpreendidos apartes- e, evocando o facto de servir o país num momento grave, termina por dizer-se «um republicano das horas difíceis e não um republicano das horas de regabofe!» (205). O incidente fica pouco depois encerrado: pesará, contudo, largos anos no espírito de Sérgio.

\section{Intercâmbio científico e acção cultural}

No âmbito propriamente do intercâmbio científico, a intervenção de Sérgio, sendo modesta, marcou todavia uma directriz definida.

Sem subestimar o intercâmbio luso-francês - louvará publicamente Júlio Monteiro Aillaud pela proficiência, zelo inexcedível e competência postos na organização da Biblioteca de Literatura Portuguesa junto da Universidade de $\mathrm{Pa}$ ris (206) — terá o cuidado de ampliar o campo da Comissão

(**) Diário da Câmara dos Deputados, Sessão n. ${ }^{\circ}$ 28, 25-1-1924, pp. 11 e ss.

$\left.\mathbf{r}^{5}\right)$ Sobre este assunto, ver, ainda, Diário de Lisboa, 25-1-1924 e: R.P. [Raul Proença], "António Sérgio e o seu monarquismo ante o olhar purissimo de certas vestais republicanas», in Seara Nova, (29), 20-1-1924, pp. 100-101.

Na véspera da sessão parlamentar, Sérgio participara, como convidado, no Centro Tomás Cabreira, numa sessão comemorativa do aniversário de Monsanto. Vejam-se, acerca dessa sessão, $O$ Rebate e o Diário de Lisboa, de 25-1-1924, e ainda Seara Nova, (30), de 31-1-1924, pp. 113-114.

Cf. ainda, sobre as palavras de Sérgio, a interessantíssima carta endereçada de Paris a Bernardino Machado, possivelmente em 1932, publicada por Jacinto Baptista no Correio do Minho, 15-1-1983.

$(* *)$ Diário do Governo, $2 .^{\mathrm{a}}$ série, n. ${ }^{\circ} 43,22-2-1924$, p. 683. 
de Intercâmbio Universitário Franco-Português, «de modo que ela possa não só organizar o intercâmbio universitário com outras nações além da França, mas ainda estender a sua acção a outros ramos de ensino», pelo que passaria a designarle «Comissão de Intercâmbio Intelectual» $\left({ }^{207}\right)$.

Essa diversificação do intercâmbio científico traduziu-se de imediato no encetamento de negociações com a Alemanha, a Espanha e a Itália, sendo o ensino de continuação o tema das conversações com o primeiro daqueles países $\left({ }^{208}\right)$.

No plano cultural interno, o Governo, sob proposta de Sérgio, prorrogaria o contrato do Teatro de S. Carlos com a companhia que, nesse momento, detinha a sua exploração.

Também essa decisão seria objecto de controvérsia, recaindo a acusação de "escândalo» sobre Sérgio. A Seara Nova defendê-lo-á em termos que reproduzem, certamente, o ponto de vista do ministro e que punham em causa a lisura desses ataques, movidos, segundo parece, pelo empresário José Loureiro. «Militam, como dizia uma das informações da respectiva repartição, a favor dessa deliberação fortes razões morais, escreve a Seara. A sociedade actual não só tem por vezes lutado com extremas dificuldades e realizado verdadeiros sacrifícios, como prestou um alto serviço à República, reabrindo aquele Teatro, que os inimigos do regime diziam para sempre fechado. Além disso, - e esta razão é decisiva - enquanto a actual sociedade é composta de pessoas cultas e competentes no género que aquele Teatro explora, e tem, durante a sua gerência, prestado reais serviços à Arte, o empresário Loureiro, que thes disputava o contrato, pertence a um trust de teatros, ao qual o Estado nunca poderia pertencer, pois deve servir apenas a Arte e a cultura artística e não a sua perigosa industrialização» $\left({ }^{209}\right)$.

No referente à investigação histórica, não se pode afirmar que Sérgio lhe tenha prestado mais do que apoio moral. Se, de facto, louva publicamente o cônsul de Portugal em Tânger e o sr. Michaus Bellaire pela conservação de monumentos respeitantes à presença portuguesa, deve-se-lhe tam-

$\mathrm{C}^{207}$ ) Portaria n. ${ }^{\circ}$ 3915, idem, 1 a $^{\mathrm{a}}$ série, n. ${ }^{\circ}$ 43, 15-2-1924, p. 318.

(208) Seara Nova, (34)..., cit., p. 196.

$i^{209}$ Idem, (29), Janeiro, 1924, p. 92. Sérgio respeitaria, escrupulosamente a autonomia de órgãos, oficiais ou nã̃o, ligados à vida artística. Ver os despachos de confirmação de eleições para o Conselho Teatral, para os lugares de tesoureiro da Sociedade Artística do Teatro Nacional de Almeida Garrett e do Conselho de Administração do Cofre de Subsídios e Socorros do mesmo Teatro: Diário do Governo, 2. a série, n. ${ }^{\circ} 28,4-2-1924$, p. 436. 
bém o decreto n. ${ }^{\circ}$ 9404. Sob proposta do inspector das Bibliotecas Eruditas e Arquivos Nacionais, eleva 150 por cento, sobre os 100 por cento estabelecidos pelo decreto de 29 de Julho de 1921, as importâncias fixadas nas tabelas anexas ao regulamento da Torre do Tombo e respeitantes aos emolumentos devidos aos funcionários por certidões e cópias particulares $(210)$.

Ainda que tais subidas de preços incidissem, sucessivamente, sobre tabelas existentes desde 1901, a verdade é que surgiam num momento de agravamento das condições de vida, tornando-se factores obstrutivos ao desenvolvimento da pesquisa arquivística.

\section{Conclusão}

Entre outras discordâncias, a chamada «questão dos sargentos» precipitaria a saída do Governo dos representantes do Grupo «Seara Nova» (211).

Sérgio apontaria, contudo, como causa principal do seu próprio pedido de demissão, o não ter podido começar a executar a lei de criação da Junta de Orientação dos Estudos pelo facto de o Parlamento não haver chegado a discutir o diploma que permitiria obter a necessária receita $\left({ }^{212}\right)$.

No âmago da sua política educativa achava-se, pois, esse organismo de investigação e inovação pedagógicas. Através dele, era seu projecto criar um microsistema paralelo, a partir do qual faria irradiar o impulso de reelaboração global. A reforma do sistema far-se-ia, portanto, por intermédio das pressões endógenas ao nível da instituição escolar e não por intermédio das pressões exógenas, isto é, das activações procedentes, precisamente, das forças sociais interessadas - movimento operário e democrático, professorado - em que se apoiaria uma política de educação efectivamente inovadora.

A opção «reformista» de Sérgio, (condizente, aliás, com o seu reformismo social), é a razão fundamental do malogro * 29

29, 6-2-1924.

$\left.\mathrm{C}^{210}\right)$ Idem, $1 .^{\mathrm{a}}$ série, n. $^{\circ}$ 25, 2-2-1924, p. 210; idem, 2. a série, n. ${ }^{\circ}$

(211) «O Grupo Seara Nova ao país. Porque razão abandonaram o governo os ministros indicados pelo Grupo ao sr. Presidente do Ministério», in Seara Nova, (34), 9-4-1924, pp. 191 e ss.

(212) Cf. Jacinto Baptista, «Cartas inéditas...», cit. 
completo da sua política como Ministro da Instrução em relação aos objectives principais.

Sérgio aspirava indiscutivelmente à democratização do sistema de ensino. No Centro Tomás Cabreira, durante o acto comemorativo do aniversário de Monsanto, e depois de suportar cerca de três horas de exaltadas dúvidas sobre o seu republicanismo, abordará o tema «da educação republicana, da instrução pública democrática».

Como a definia o ministro seareiro?

As necessidades da instrução pública no nosso país por ele reputadas «mais urgentes» seriam «o aperfeiçoamento dos nossos técnicos nas melhores escolas do estrangeiro e a democratização do ensino». Por esta, entendia Sérgio a existência de escolas onde, afirmava, «se adquiram hábitos, aquelas maneiras de proceder, que devem caracterizar o cidadão republicano», ou seja, "fazer da própria escola, do conjunto dos estudantes, uma sociedade democrática».

Sérgio critica fortemente, por um lado, a educação ideológica, promovida pelo republicanismo pequeno-burguês, assente, diz, na «pregação de doutrinas políticas, sociais e religiosas» pelos respectivos mestres, considerando-a contraproducente.

Evocando os seus estudos sobre educação cívica, propõe, como alternativa, a organização da escola sob o que chama «a forma de democracia», isto é, «elegendo os seus magistrados, desde o Presidente da República até aos vereadores e aos juízes, e habituando-se assim a proceder republicanamente. Seria isto, senhores, conclui nesta parte da sua intervenção, a democratização da mocidade, não por palavras mas por actos»».

Em segundo lugar, Sérgio critica também o carácter abstracto e livresco do ensino republicano, a separação entre o trabalho intelectual e o manual. «Democratizar a escola» seria, ainda, no seu entender, "desvanecer o mais possível a velha distinção das classes liberais e das classes mecânicas, obrigando os futuros cidadãos, a qualquer classe que eles pertençam, ao trabalho manual na escola; dando carácter e base científica e portanto liberal, aos trabalhos mecânicos; colocando nas mesmas escolas, em comunidade de trabalho, os filhos do povo e os da burguesia, e organizando os grupos de alunos em corporações profissionais»».

Democratizar a escola seria, finalmente, «dificultar o acesso das altas carrreiras universitárias aos filhos dos ricos que não têm capacidade para os mais difíceis trabalhos de 


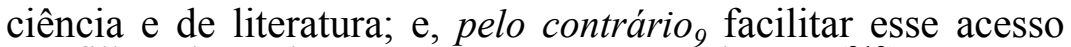
aos filhos dos pobres que nasceram com talento» $\left({ }^{213}\right)$.

Sérgio não ultrapassa, quanto ao primeiro e segundo pontos, o formalismo burguês em que se inspirava o movimento da escola nova e de que fora, na realidade, esforçado divulgador entre nós $\left({ }^{214}\right)$. Formalismo na medida em que se limita a reproduzir na «comunidade» escolar a forma democrática burguesa da organização do Estado. Formalismo na medida em que a união do trabalho manual e do trabalho intelectual não se liga de facto à produção material e acaba por conduzir, por esse facto, ao «bricolage». Formalismo, ainda, na medida em que a «comunidade» escolar não constitui, verdadeiramente, uma comunidade de pessoas enfrentando problemas comuns mas um agregado de jovens procedentes das classes sociais antagónicas realmente existentes na sociedade global.

Sem menosprezar o considerável avanço ideológico que tais concepções apresentam na evolução das teorias pedagógicas entre nós, sobretudo quando as confrontamos com a prática educativa republicana, elas não ultrapassam, todavia, as limitações inerentes a toda a filosofia pedagógica da escola nova. Constituem, de facto, o extremo limite a que chegaria a consciência pedagógica pequeno-burguesa.

$\ddot{E}$ visível ter Sérgio renunciado, à data do seu ingresso no Ministério da Instrução, à ideia de uma reforma global, ele que fora um colaborador, exigente e actuante, do projecto de João Camoesas.

E certo que a Comissão Pedagógica, por ele nomeada, recebeu a orientação de se guiar pelas bases gerais do projecto de Camoesas. Mas, para além disso, Sérgio nada chegou a fazer para que esse projecto fosse avante.

Por falta de tempo? Ou porque dele o separava uma distância que não revelara antes publicamente, e porque reconhecia agora, no concreto, as dificuldades da sua aplicação?

Sob esse aspecto, são relevantes as palavras proferidas na passagem de testemunho a Helder Ribeiro. «Está pendente dos Deputados um projecto de lei que ali apresentou um dos nossos antecessores, dirá. Tendo sido chamado a interferir na redacção desse projecto, e a dar-lhe uma revisão sumária de carácter pedagógico e estilístico, quase que só prestei

\footnotetext{
(213) Para tudo o que precede ver Seara Nova, (30), ...» cit., pp. 113-114

$\left.\dot{C}^{14}\right)$ Ver o nosso estudo A Pedagogia Portuguesa Contemporanea, cit.
} 
atenção à sua parte pedagógica, pois que no que respeita à administrativa havia divergếncias fundamentais entre mim, por um lado, e pelo outro o sr. Faria de Vasconcelos e o Ministro Sr. João Camoesas: a reunião de todos os órgãos no gabinete do Ministro-, sob a presidência do respectivo chefe, julguei-a sempre insustentável. Parecendo-me boas as intenções daqueles senhores, e as genéricas directrizes da parte pedagógica do projecto, prestei-lhes a minha colaboração, com a condição de se pôr em relevo o que eu classificava de susceptível de realização imediata, e reservando-me o discutir pormenores quanto chegasse a oportunidade. Não pude impulsionar a discussão do projecto durante a minha estada no Ministério, esclarece, porque o Sr. Dr. João Camoesas, membro e presidente de uma das Comissões parlamentares de instrução pública, declarou-me ser-lhe impossível o tratar de tais assuntos (porque estava então a fazer um livro), ajunta Sérgio com ironia. Pelo que toca ao Dr. Faria de Vasconcelos, sofreu de desgostos e de doenças, que o impediram de trabalhar e de falar comigo, desde a minha entrada no Ministério. Por isso, repito, nada pude adiantar em tal assunto» (215). imediato.

Perante esta explicação, algumas dúvidas ressaltam de

Em primeiro lugar, para salientar que nunca Sérgio dera a conhecer, durante o debate público do projecto de reforma, a divergência de fundo agora manifestada. Tratar-se-ia, de facto, de um «pormenor» a deixar para momento ulterior?

Em segundo lugar, para manifestar estranheza pelo facto de Sérgio ter considerado como razão bastante para a travagem da discussão do projecto, os momentâneos impedimentos, supostos ou reais, de João Camoesas e Faria de Vasconcelos. Seriam esses os únicos interlocutores válidos no processo de negociação que a aprovação e implementação de tal reforma imnlicava?

Sob este aspecto é significativa a posição do movimento operário, ou, pelo menos, da sua vanguarda.

Num incisivo artigo publicado sem assinatura após a exoneração de Sérgio (216) A Batalha traçava um sombrio balanço da sua política de educação.

(215) Seara Nova, (34),..., cit., p. 196. Estas afirmações de Sérgio sobre a sua colaboração na reforma de Camoesas trazem nova luz acerca da sua frustração por não ter achado em Faria de Vasconcelos um aliado natural contra o político.

(216) «Palavras, palavras... e palavras. A obra do sr. António Sérgio, ministro da Instrução. Com esta nova experiência política, o Grupo 'Seara Nova' é mais uma ilusão que se desfez», in A Batalha. Suplemento semanal ilustrado, 1 (14), 3-3-1924, p. 2. 
Salientava o articulista anónimo, em primeiro lugar, ter a proposta de reforma de João Camoesas despertado vivamente o interesse do proletariado pelo problema pedagógico, «interesse que até então não havia sido exteriorizado» pela descrença absoluta de que dentro do regime republicano pudesse ser tentada «uma honesta e proficiente obra pedagógica».

O proletariado apoiara, nesse ponto, João Camoesas, manifestando «que compreendia e aplaudia o alcance da reforma» e para o incitar a dar-lhe plena execução.

Se a primeira «desilusăo» em relação a Sérgio fora $A$ Batalha tê-lo visto aceitar a pasta da Instrução «num ministério que tinha por divisa - redução de despesas», do que resultou, lembra o jornal, "vermos um pedagogo, um propagandista da cultura popular consentir em reduzir as despesas com a instrução num país de analfabetos e onde em matéria de educação e ensino está tudo por fazer ainda», a segunda desilusão foi nunca se ter visto empenhado o ex-ministro em pôr em prática a mesma reforma.

O primeiro motivo de surpresa, aponta A Batalha, residia no facto de Sérgio ter colaborado nela e a ter defendido na Imprensa. O segundo, anota pertinentemente o autor do artigo, consistiu em que, «depois da condenação oficial de toda a instrução pública portuguesa» inscrita na justificação da proposta de lei, «qualquer ministro da Instrução não tem outra coisa que fazer que não seja remodelar imediatamente esse sistema educativo em vigor, condenado pelo espírito científico e desconceituado pela experiência».

Entretanto, a intervenção de Sérgio em relação ao sistema de ensino em funcionamento contradiria frontalmente a terceira componente do seu visionado processo de democratização da escola portuguesa.

A extinção do ensino primário superior vinha privar de facto os filhos dos trabalhadores e dos sectores intermédios da única via acessível, embora insatisfatória, de escolaridade pós-primária.

Devido à luta de massas desencadeada, Sérgio acabaria por ser forçado a procurar no plano imediato uma alternativa mais válida do que a criação de uma escola experimental de continuação dirigida por mestres estrangeiros e equipada com material estrangeiro. Sairia, todavia, do Ministério sem o ter conseguido.

Esse aspecto da sua política ser-lhe-ia, aliás, violentamente censurado por $A$ Batalha no artigo supracitado.

Para além de alegadas incoerências pessoais de Sérgio como ministro da Instrução, apontadas por $A$ Batalha nem sempre com justiça, condena-se-lhe o facto de ter exposto 
mais «pontos de vista» e «declarações de intenção» do que realizações efectivas.

Filiando em antagonismos de orientação ministerial a inoperância de que a burguesia sempre dera provas na instrução pública, A Batalha censurava depois a incapacidade do ex-ministro para achar soluções alternativas às negativas realidades existentes. «O Sr. António Sérgio disse mal da organização das Escolas Primárias Superiores. O Sr. António Sérgio disse mal dos programas; são maus, péssimos, monstruosos, acentuava o jornal operário. Mas não deu um modelo, concreto, de um bom programa feito por ele».

Agravado o descalabro em que se achava esta via de escolaridade pós-primária, caía igualmente por terra o proclamado propósito de democratização do acesso ao ensino superior.

Ao mesmo tempo, a anunciada elevação do custo das matrículas no ensino liceal, congeminado, por um momento, na ilusória perspectiva de dificultar o acesso ao ensino superior aos filhos da burguesia sem "talento» para esses altos níveis de ensino e de, pelo contrário, facilitá-lo aos filhos dos «pobres» por um sistema de bolsas, adquiria, no plano imediato, uma significação iniludível, à falta de outros mecanismos de discriminação positiva: a de tornar ainda mais inacessível tal ramo de ensino aos beneficiários supostos dessa medida.

A concretização dos referidos mecanismos pressupunha a reorganização e democratização da escola elementar e pós-elementar, bem como a eliminação de todas as causas sócio-económicas de insucesso escolar e de abandono dos estudos: o trabalho infantil e juvenil, as condições de vida, a frequência irregular da escola, a própria situação de «privação cultural» das classes trabalhadoras e das camadas intermédias.

Ora, a intervenção de Sérgio é em extremo frouxa no plano da acção social escolar e do aperfeiçoamento das condições materiais de ensino sob o ponto de vista de instalações e de equipamento.

No plano da prática pedagógica, é certo caber-lhe o assinalado mérito de ter tentado introduzir inovações quanto aos métodos de ensino da leitura e à utilização do cinema educativo. Os efeitos de tais inovações, porém, só se fariam sentir a prazo, e ainda assim com a condição de existirem os meios didácticos indispensáveis, e a esse problema também Sérgio não deu resposta satisfatória.

Em contrapartida, sem ter em conta as determinantes sócio-culturais do insucesso escolar, (como, aliás, a médico-pedagogia do tempo), Sérgio recorreria à criação do chamado 
ensino especial, com a abertura de «classes especiais» junto das escolas primárias. Assente a selecção dos alunos no mais rasteiro empirismo, que lhe é proposto por uma Comissão mais atenta à falta de recursos financeiros do que às necessidades de organização de tal ensino em bases científicas, muitas crianças portuguesas viriam a ser desviadas para essas «classes-ghetto» devido a insucessos cuja origem não era, de facto, a «anormalidade» mas, pelo contrário, as condições sócio-culturais familiares.

Se pertence indiscutivelmente a Sérgio a iniciativa de ter ensaiado pela primeira vez entre nós um serviço de ensino especial, cabe-lhe igualmente a responsabilidade histórica de ter podido insinuar-se através dele o que não passaria da sua completa mistificação, facto que, façamos-lhe justiça, teria sido o primeiro a repudiar se disso houvesse podido aperceber-se nestes dias de hoje.

Por outro lado, é patente a sua incapacidade para satisfazer as reivindicações imediatas do professorado, acumuladas ao longo dos anos e dos sucessivos governos. A dualidade das suas atitudes em relação ao «diálogo» com os docentes, o seu paternalismo para com a fracção mais numerosa dos professores - os dos graus primários - em contraste com a sua disponibilidade para com os de outros graus de ensino, o agravamento generalizado das condições de trabalho, ditadas de cima mesmo quando parecem justas, priva Séreio de qualquer apoio entre os que poderiam ser, alguma vez, os seus parceiros num projecto praticável de reestruturação do sistema.

Sérgio não se revelou nunca à altura de compreender as dificuldades mais sentidas pelo professorado de que se achava profissionalmente e culturalmente distante. Tudo isto, ainda, agravado pela orientação do Governo de que fazia parte em relação ao funcionalismo público, professores incluídos, governo cujo Conselho de Ministro chega a deliberar a suspensão dos funcionários em greve $\left({ }^{217}\right)$.

Sob esse aspecto, são particularmente significativos o seu conflito com o Reitor e, depois, com o próprio Senado da Universidade de Coimbra, bem como a flagrante desatenção a que devotou as dificuldades de funcionamento dos institutos científicos. Exceptuada a criação do Instituto do Cancro e a tentativa de solução para o problema das instalações

(2X7) $Q$ século, 28-2-1924. O facto de Sérgio ter sido exonerado nesse mesmo dia é diferente, se atendermos ao que a Seara Nova escreve a propósito das greves. Cf. Seara Nova (34), cit. 
da Faculdade portuense de Medicina, Sérgio daria escassa importância ao ensino superior, em relação a cuja frequência, como vimos, adoptou uma orientação malthusiana.

Deste modo, se é certo que as chamadas «forças vivas» não terão visto com maus olhos o seu projecto de uma escola experimental de continuação, isto é, de criação de um ensino técnico como futura alternativa ao ensino primário superior; se é certo que a burguesia capitalista aceitava de bom grado essa via de formação da mão-de-obra de que carecia, já o mesmo se não poderia dizer dos obstáculos propostos por Sérgio à frequência do ensino liceal e universitário.

O perigo potencial que tais concepções representavam feria os interesses da própria burguesia republicana e democrática que, por momentos, se incorporava na luta unitária de massas contra o avanço das forças reaccionárias. A este aspecto da sua política adicionava-se o facto de não ter tido Sérgio o tacto nem a sensibilidade necessárias para evitar situações equívocas que lhe alienariam o apoio poltíico necessário no Parlamento.

Sérgio perderá, por isso mesmo, todos os suportes sociais necessários à reestruturação progressista do sistema de ensino.

Por outro lado, não é menos certo que o movimento operário, de que $A$ Batalha constituia, ao tempo, a ponta de lança, nem sempre soube achar a via mais correcta paa a condução da luta.

Esquecendo que o motor da reestruturação dos sistemas de ensino são as novas exigências da sociedade global, expressas através do poder político, A Batalha renunciava a uma firme e consequente posição de classe e caía num voluntarismo e imediatismo sem perspectivas.

Assim, no mesmo balanço crítico que censurava a Sérgio o abandono do projecto Camoesas, A Batalha acabaria por apostar, afinal como o ex-ministro da Instrução Pública, na reelaboração endógena do sistema de ensino.

«A nosso ver o mal ou bem não está nas leis, nem nos regulamentos ou programas, afirmava-se no mesmo artigo. Uma boa interpretaçã̃o, uma boa execução, ou abnegação, com carolice, com paixão sentida e não fingida, e com liberdade e boa fé seria o suficiente para fazer com eficácia a grande obra da Educação».

Esta concepção voluntarista tinha, adiante, uma particularização surpreendente: «Se quem interpreta tem boa orientação pedagógica e boa vontade em acertar, se o educador não é apenas um funcionário do Estado pago às horas, que faz o mínimo que pode e falta o mais que pode; se há inte- 
ligência, saúde moral, concluía-se, todos os programas são bons».

Ia mais longe ainda $A$ Batalha. «Não são precisas mais reformas, mais leis e regulamentos, acrescentava; o que era necessário era acabar com o ministério de Instrução Pública que faliu e entregar a obra da Educação aos pedotécnicos»».

Este simplista modo de ver, era a seguir desdobrado numa série de pontos programáticos que, afinal, contradiziam a peregrina ideia de entregar o ensino aos «pedotécnicos». Assim, seria preciso «emancipar o professorado dos vexames da $10{ }^{a}$ Repartição de Contabilidade». Ao mesmo tempo, «sanear o ensino, limpando-o dos aventureiros, dos parasitas, que fazem do magisterio um balcão»; purificar - é o termo usado - «a atmosfera social das escolas, desinfectando-as de toda a espécie de reacções em que os falsos educadores fazem um criminoso trabalho de destruição, e uma propaganda dissolvente a favor de todos os vícios que corroem a sociedade em que vivemos».

Nos seus diversos temas, como poderia tal programa concretizar-se independentemente do contexto real da luta de classes e da questão do poder? Desprovida de uma concepção ideológica que lhe permitisse analisar a questão do ensino e da reelaboração do respectivo sistema, A Batalha não ultrapassava, no fundo, o acanhado horizonte do republicanismo pequeno-burguês. O problema político reduzia-se, erroneamente, a mera questão de homens. Quanto às escolas-modelos evocadas por Sérgio, por exemplo, se a sua utilidade era posta em dúvida, era porque tais escolas ficariam «à mercê dos vendavais da política e do capricho de um ministro qualquer, que, embirrando com elas, as extinguirá com uma penada ou as reformará segundo o figurino alemão, norte-americano, francês, suíço!». As escolas-modelos seriam benvindas, rematava $A$ Batalha, se «quem as organize e faça funcionar nos garanta que é um modelo de probidade e de moralidade e autêntica e sincera dedicação à causa da educação do Povo!» $(218)$.

Fazer depender unicamente da vontade e «boa consciência» individuais a reelaboração de um sistema de ensino, isolando esse processo de todo o contexto social, imaginar que a «causa da educação do Povo» poderia ter solução independentemente da questão do poder - e portanto da questão do Estado e da luta de classes - era uma ilusão de que também A Batalha se não dava conta.

(218) A Batalha. Suplemento..., cit. 
Sérgio representa, sem dúvida, a linha mais avançada da filosofia pedagógica da burguesia liberal republicana. $\mathrm{O}$ seu esforço de aprofundamento teórico das questões da educação e do ensino constitui o legado mais positivo e mais firmemente articulado do pensamento português do tempo e uma das mais lúcidas manifestações do ideário internacional da «escola nova» no nosso país.

As suas concepções contêm aspectos progressistas que a prática pedagógica de hoje incorpora e rectifica em projectos educacionais de mais ampla dimensão. A educação e o ensino não se processam num «deserto social», na atmosfera «pura» de um «laboratório escolar», mas no duro terreno da luta histórica.

Sendo assim, um sistema de ensino, qualquer que ele seja, nos seus ciclos sucessivos de reelaboração, é expressão dessa mesma luta e está indissoluvelmente ligado aos ciclos de transformação da própria sociedade global. 